\title{
Mormon Cricket Control in Utah's West Desert- Evaluation of Impacts of the Pesticide Diflubenzuron on Nontarget Arthropod Communities
}

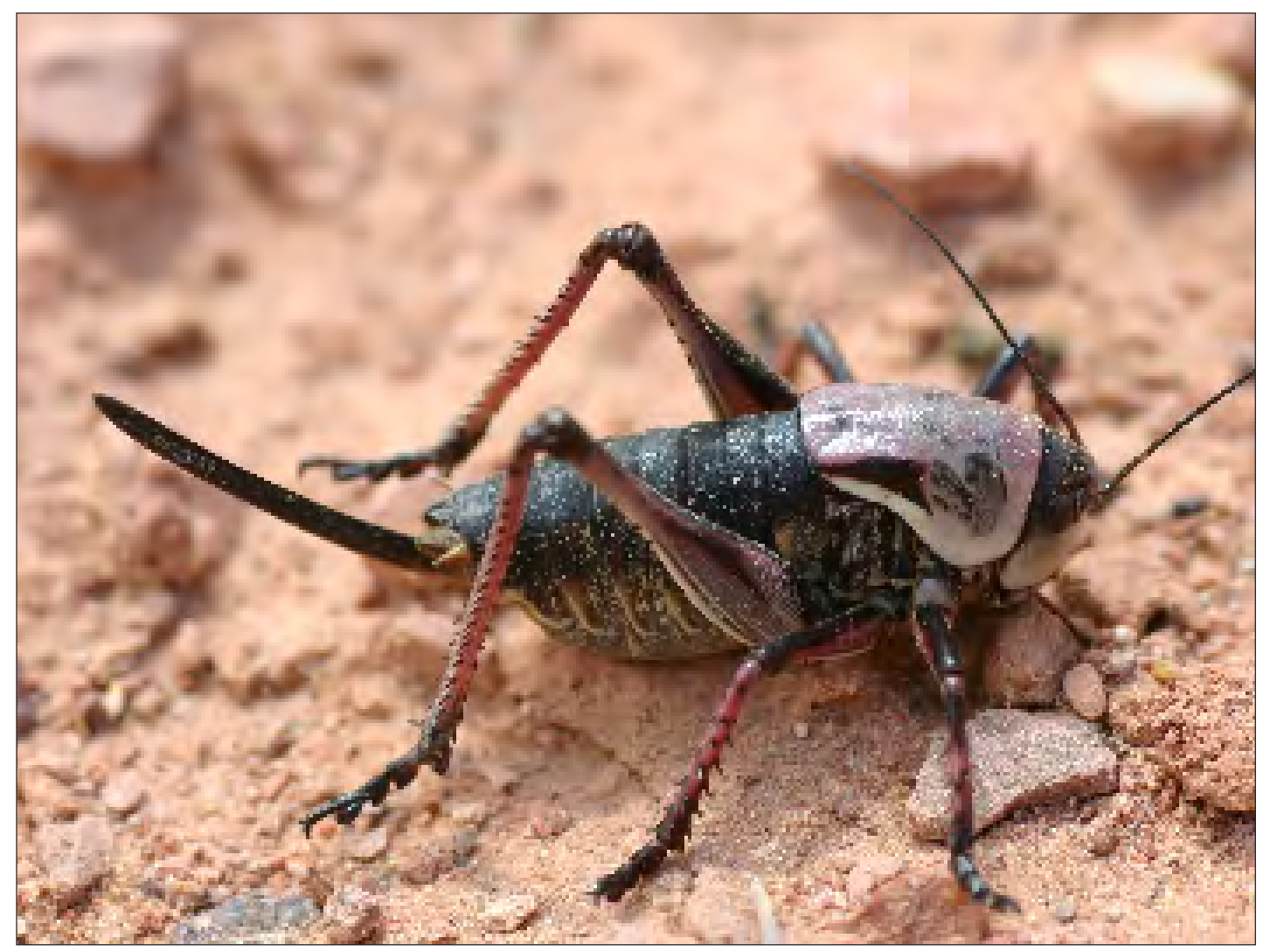

Open-File Report 2008-1305 
This page intentionally left blank 


\title{
Mormon Cricket Control in Utah's West Desert-Evaluation of Impacts of the Pesticide Diflubenzuron on Nontarget Arthropod Communities
}

\author{
By Tim B. Graham, Anne M.D. Brasher, and Rebecca N. Close
}

Open-File Report 2008-1305 


\section{U.S. Department of the Interior DIRK KEMPTHORNE, Secretary}

\section{U.S. Geological Survey \\ Mark D. Myers, Director}

\section{U.S. Geological Survey, Reston, Virginia: 2008}

For product and ordering information:

World Wide Web: http://www.usgs.gov/pubprod

Telephone: 1-888-ASK-USGS

For more information on the USGS--the Federal source for science about the Earth, its natural and living resources, natural hazards, and the environment:

World Wide Web: http://www.usgs.gov

Telephone: 1-888-ASK-USGS

Any use of trade, product, or firm names is for descriptive purposes only and does not imply endorsement by the U.S. Government.

Although this report is in the public domain, permission must be secured from the individual copyright owners to reproduce any copyrighted materials contained within this report.

Suggested citation:

Graham, T.B., Brasher, A.M.D., and Close, R.N., 2008, Mormon cricket control in Utah's west desert; evaluation of impacts of the pesticide diflubenzuron on nontarget arthropod communities: U.S. Geological Survey Open-File Report 2008-1305, 82 p. [http://pubs.usgs.gov/of/2008/1305/].

Cover: Female Mormon cricket (Anabrus simplex); U.S. Geological Survey photograph by Tim Graham. 


\section{Contents}

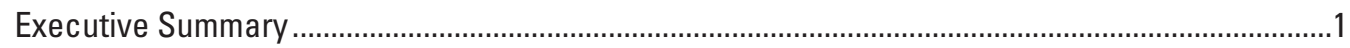

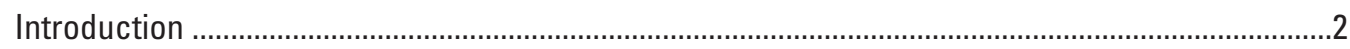

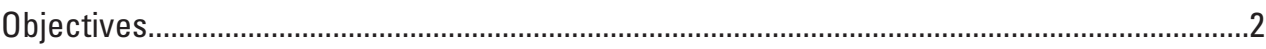

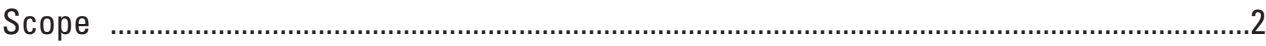

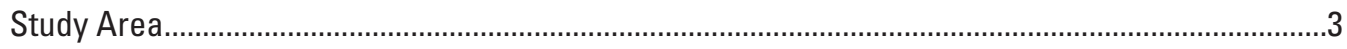

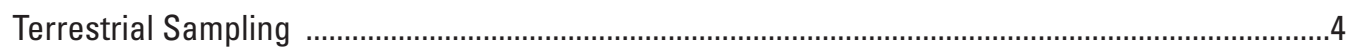

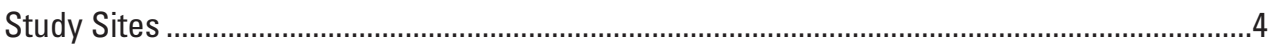

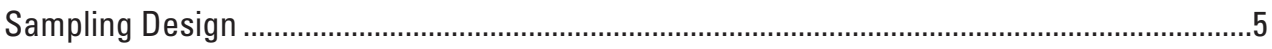

Sample Collection and Processing ........................................................................................

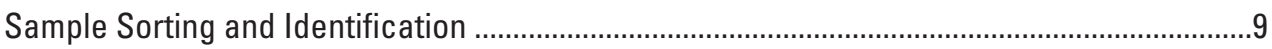

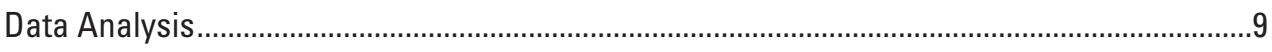

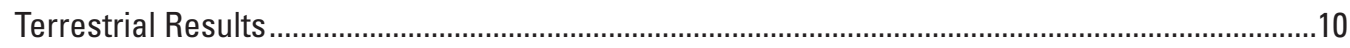

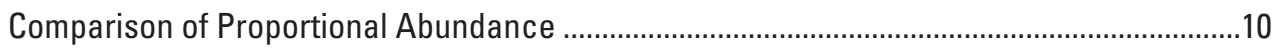

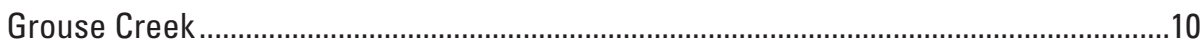

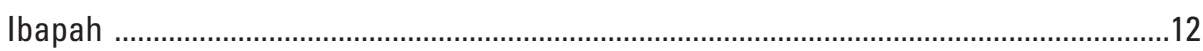

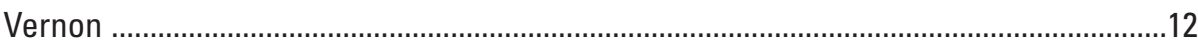

Comparisons of Abundance by Orders in Treated and Untreated Zones...............................13

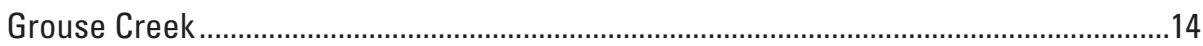

Pre- versus Post-Treatment Changes in Untreated Zone .....................................14

Pre- versus Post-Treatment Changes in Treated Zone .........................................17

Pre-Treatment Changes in Untreated versus Treated Zones..................................17

Post-Treatment Changes in Untreated versus Treated Zones .................................17

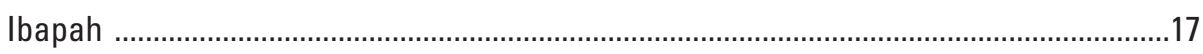

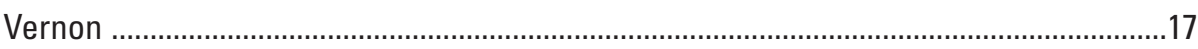

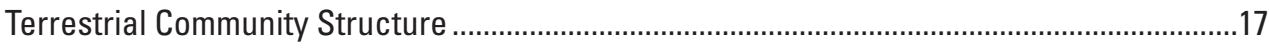

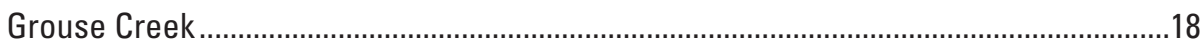

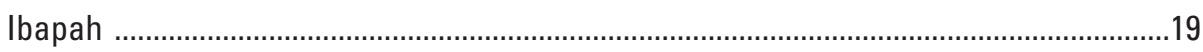

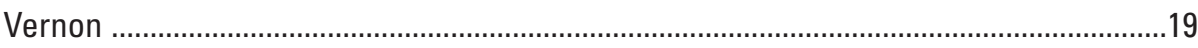

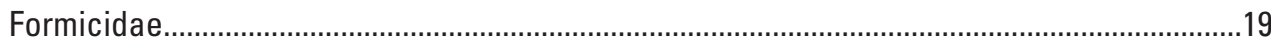

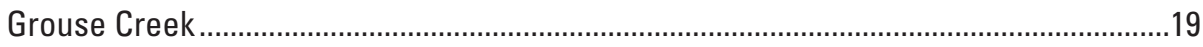

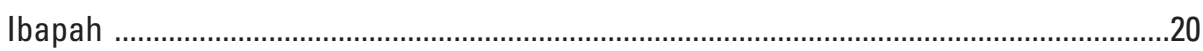

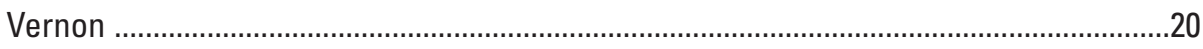

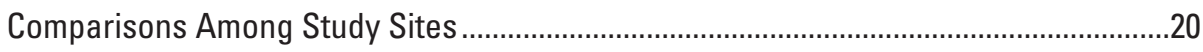

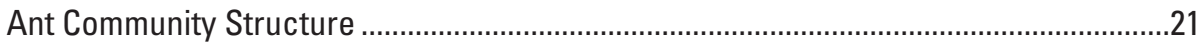

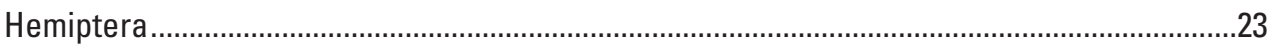

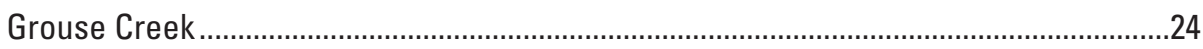

Pre- versus Post-Treatment Changes in Untreated Zone ......................................24

Pre- versus Post-Treatment Changes in the Treated Zone........................................24

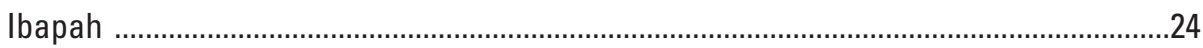

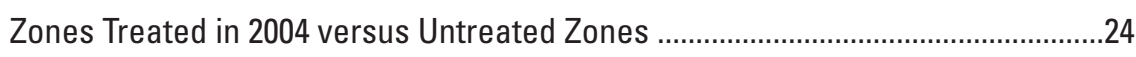

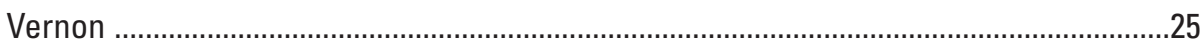

Sites Treated in 2004 versus Untreated Sites.......................................................25 


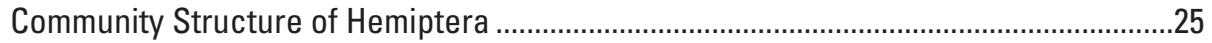

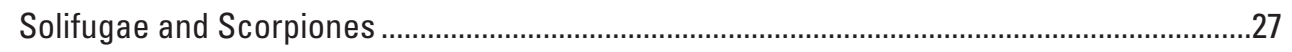

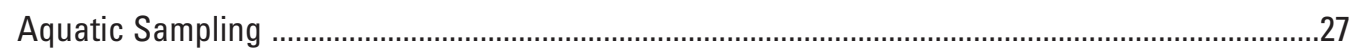

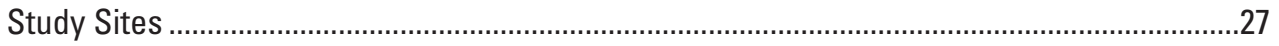

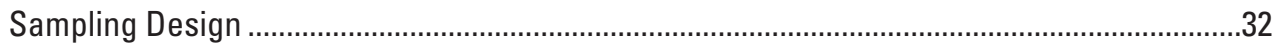

Sample Collection and Processing .....................................................................................

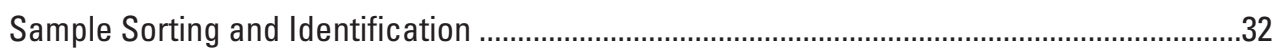

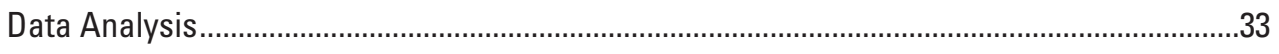

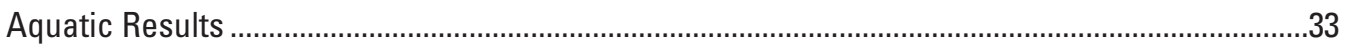

Aquatic Macrofauna by Study Area ................................................................................3

Richness, Abundance, and Diversity at Sampling Sites in the Three Study Areas.................40

Grouse Creek .......................................................................................................

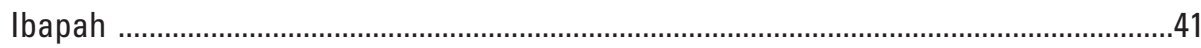

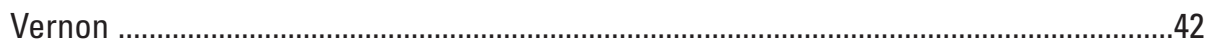

Macroinvertebrates in the Grouse Creek Treatment Zone ...................................................4

Aquatic Community Structure ……………………….......................................................4

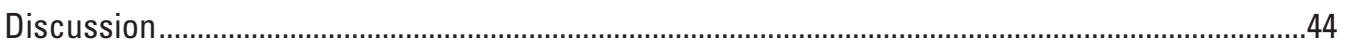

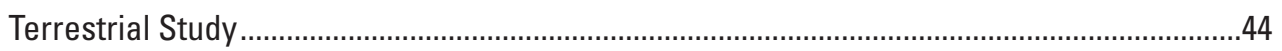

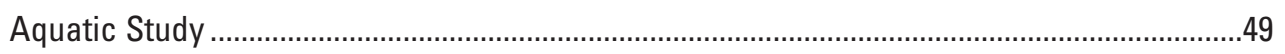

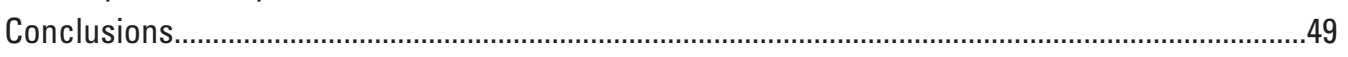

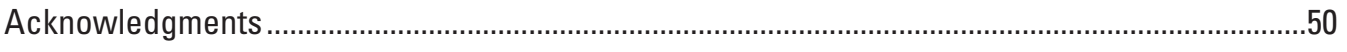

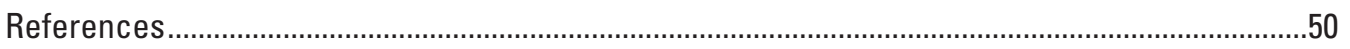

Appendix A: Terrestrial Taxa Collected—Total Number of Arthropods Caught During Each

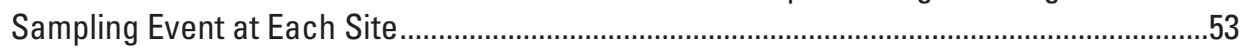

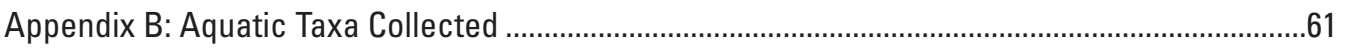

\section{Figures}

1. Mormon crickets on the road at Grouse Creek study site in May 2005 ............................2

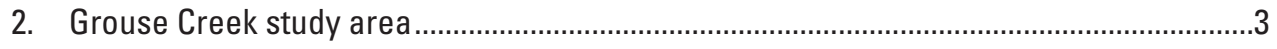

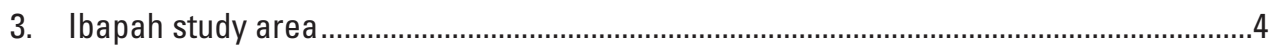

4. Vernon study area ...................................................................................................

5. Typical terrestrial site at Grouse Creek study site, Utah, showing pitfall traps ..................7

6. Typical terrestrial site at Ibapah study site, Utah..........................................................

7. Typical terrestrial site at Vernon study site, Utah, showing pitfall traps............................

8. Arrangement of pitfall traps at each terrestrial arthropod sampling site of the study.....9

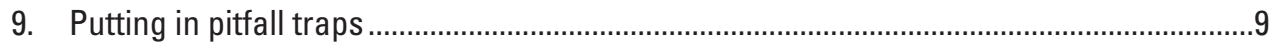

10. Processing terrestrial arthropods from pitfall trap in the field ......................................10

11. Sorting pitfall trap samples, removing debris, and identifying specimens to order........10

12. Proportional representation of taxa at the four sites in the Grouse Creek......................11

13. Proportional representation of taxa at the four sites in the Grouse Creek......................12

14. Proportional representation of taxa at the eight Ibapah sites ........................................13

15. Proportional representation of taxa at the eight Vernon sites.........................................14 
16. Average number of individuals (by taxon) at the three study areas................................15

17. Nonmetric multidimensional scaling ordination for all sites ..........................................18

18. Relative abundance of ant genera at Grouse Creek .......................................................21

19. Relative abundance of ant genera at Ibapah untreated and treated zones.....................22

20. Relative abundance of ant genera at Vernon untreated and treated zones ...................22

21. Nonmetric multidimensional scaling joint plot of ant genera as number of ants per day at Grouse Creek, Ibapah, and Vernon ............................................................................23

22. Relative abundances of Hemiptera families at Grouse Creek untreated and treated zones before and after treatment with diflubenzuron. ...................................................25

23. Relative abundances of Hemiptera families at Ibapah treated and untreated sites ......26

24. Relative abundances of Hemiptera families at Vernon untreated and treated sites ......26

25. Nonmetric multidimensional scaling ordination of Hemiptera families at the three study areas.

26. Number of wind scorpions per day versus number of scorpions per day at lbapah study

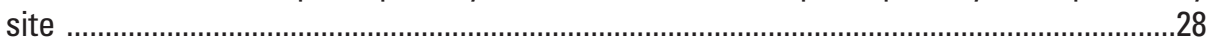

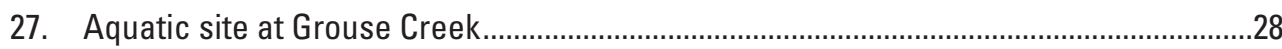

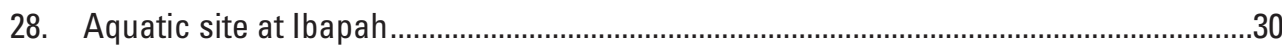

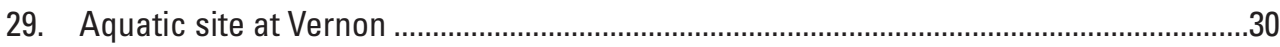

30. Collecting an aquatic macroinvertebrate sample using a D-frame net ..........................32

31. Cluster Spring 2 at Grouse Creek, within the treated zone ...............................................33

32. Aquatic macroinvertebrate sampling at one of the study streams..................................33

33. Relative abundances of aquatic taxa in springs and streams at the Grouse Creek

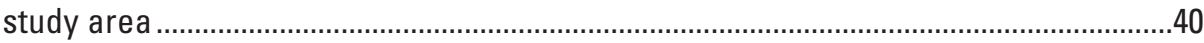

34. Relative abundances of aquatic taxa in springs and streams at the Ibapah study

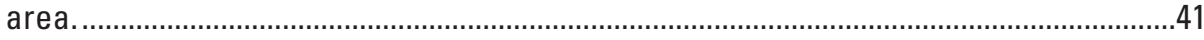

35. Relative abundances of aquatic taxa in streams at the Vernon study area ....................41

36. Taxa abundance and richness and diversity inside and outside diflubenzuron treatment zones at Grouse Creek, only after treatment ..................................................................42

37. Taxa abundance and richness and diversity inside and outside diflubenzuron treatment zones at Grouse Creek, all sampling dates included.

.43

38. Taxa abundance and richness and diversity inside and outside diflubenzuron treatment zones at Ibapah

39. Taxa abundance and richness and diversity inside and outside diflubenzuron treatment zones at Vernon

40. Taxa abundance and richness before diflubenzuron treatment, 2 weeks after treatment, and 4 months after treatment, at the Grouse Creek study area.

41. Nonmetric multidimensional scaling joint plot with aquatic macroinvertebrate relative taxa abundances

\section{Tables}

1. Terrestrial site and sampling information

2. Ant genera found in each west desert treatment zone and during each sampling period. 
3. Total number of ants collected in treated and untreated zones at Grouse Creek after treatment with diflubenzuron

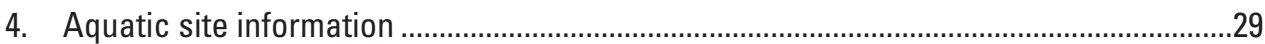

5. Aquatic site characteristics and sampling information .....................................................

6. Aquatic taxa collected at the three west desert study areas...........................................34 


\title{
Mormon Cricket Control in Utah's West Desert- Evaluation of Impacts of the Pesticide Diflubenzuron on Nontarget Arthropod Communities
}

\author{
By Tim B. Graham', Anne M.D. Brasher ${ }^{2}$, and Rebecca N. Close ${ }^{3}$
}

\section{Executive Summary}

Grasshopper and Mormon cricket (Orthoptera) populations periodically build to extremely high numbers and can cause significant economic damage in rangelands and agricultural fields of the Great Plains and Intermountain West. A variety of insecticides have been applied to control population outbreaks, with recent efforts directed at minimizing impacts to nontarget fauna in treated ecosystems. A relatively new insecticide for control of Orthoptera is diflubenzuron, which acts to inhibit chitin production, ultimately causing death during the molt following ingestion of the insecticide. All arthropods, including insects, mites, and crustaceans, use chitin to build their exoskeletons and will die if they are unable to produce it during the next molt. Diflubenzuron is not taxon specific - it affects all arthropods that ingest it, except adult insects, which do not molt. Consequently, application of this pesticide has the potential to significantly reduce not only target populations but all terrestrial and aquatic arthropods within treatment zones.

Some research has been done in the Great Plains on the impact of diflubenzuron on nontarget arthropods in the context of grasshopper-control programs, but no work has been done in the Great Basin in Mormon cricket-control areas. This study was instigated in anticipation of the need for extensive control of Orthoptera outbreaks in Utah's west desert during 2005, and it was designed to sample terrestrial and aquatic arthropod communities in both treated and untreated zones. Three areas were sampled: Grouse Creek, Ibapah, and Vernon. High mortality of Mormon cricket eggs in the wet, cool spring of 2005 restricted the need to control Mormon crickets to Grouse Creek. Diflubenzuron was applied (aerial reduced agent-area treatment) in May 2005. Terrestrial and aquatic arthropod

\footnotetext{
${ }^{1}$ U.S. Geological Survey, Southwest Biological Science Center, Canyonlands Research Station, Moab, Utah

${ }^{2}$ U.S. Geological Survey, Utah Water Science Center, Moab, Utah

${ }^{3}$ U.S. Geological Survey, Utah Water Science Center, Salt Lake City, Utah
}

communities were sampled before and after application of diflubenzuron in the Grouse Creek area of northwestern Utah in May and June of 2005. In July 2005, U.S. Geological Survey scientists sampled areas in Ibapah and Vernon that had been treated with diflubenzuron in 2004, along with adjacent untreated areas. Pitfall traps at four treated and four untreated sites were used to collect ground-dwelling terrestrial arthropods. Semiquantitative sweep surveys of aquatic habitats were made before treatment, 2 weeks after treatment, and 4 months after treatment (after leaf fall) at Grouse Creek. One-year posttreatment samples were collected by using the same methods for terrestrial and aquatic arthropods at Ibapah and Vernon in July 2005 (treatments applied in June 2004).

More than 124,000 terrestrial arthropods were collected from the three study areas, and more than 200,000 aquatic invertebrates were collected in the aquatic samples. Direct effects of diflubenzuron on aquatic and terrestrial arthropod communities were not apparent in our data from Grouse Creek. The treatment was designed to avoid spraying pesticide on water bodies, and no measurable effects on aquatic communities from either springs or streams were observed, with the exception of the reduction of taxa richness at Vernon (a result confounded by elevational differences in the treatment and nontreatment zones). Some trends indicate diflubenzuron may affect some terrestrial taxa. Ant communities showed some differences, with possible lag effects at Ibapah and Vernon. Forelius was more abundant, while Tapinoma and, perhaps, Formica declined in treated zones in these two study areas. Solenopsis also was more numerous at treated Ibapah sites but varied without pattern at Vernon. Scorpions were abundant at Grouse Creek and Ibapah but rare at Vernon. Numbers did not change during several weeks at Grouse Creek, but at Ibapah, numbers at treated sites were much lower than at untreated sites. The Lygaeidae (in the order Hemiptera) were more abundant in the untreated zones at Ibapah and Vernon, although significantly so only at Ibapah. Lygaeidae were absent from the treated zone at Grouse Creek (before and after treatment) but were present after treatment in the untreated zone. Additional research is recommended to determine more explicitly whether these taxa are sensitive to diflubenzuron applications in the Great Basin. 


\section{Introduction}

In rangeland ecosystems of the United States, populations of Orthoptera (including grasshoppers and Mormon crickets) can rapidly build to levels that cause economic damage. Despite efforts to prevent outbreaks, grasshopper (multiple species) and Mormon cricket (Anabrus simplex) populations (fig. 1) were at large levels for 5 to 6 years preceding this study in the west desert of northern Utah (U.S. Department of Agriculture, 2002). Although much of the area of outbreak was outside of cultivated lands, State and Federal agencies and private landowners were concerned about consumption of crops and range forage during these infestations. The need for rapid and effective suppression of Orthoptera when an outbreak occurs limits the control options available, and the application of an insecticide within all or part of the outbreak area has been the primary response for rapid suppression or reduction of Orthoptera populations to effectively protect rangeland. Control efforts have been implemented in Utah's west desert since 2002 in areas of particularly large Orthoptera populations.

The primary chemicals used for control of grasshoppers and crickets are carbaryl, applied as bran bait, and diflubenzuron, applied as an aerial spray. However, because the use of carbaryl in Utah's west desert has been greatly curtailed and is more localized, we focused on diflubenzuron treatments. Diflubenzuron is a chitin-inhibiting agent, causing arthropods to die during the molting process. Arthropods (including insects, arachnids, and crustaceans) have a hard exoskeleton made of chitin. Since diflubenzuron is a chitin-inhibitor, it affects nontarget arthropods, as well as grasshoppers and crickets. Previous studies have shown that although diflubenzuron is not directly toxic to vertebrates, birds can be indirectly affected when this pesticide reduces availability of key prey items (Sample and others, 1993). Consequently, a major concern in the west desert is that by killing nontarget arthro-

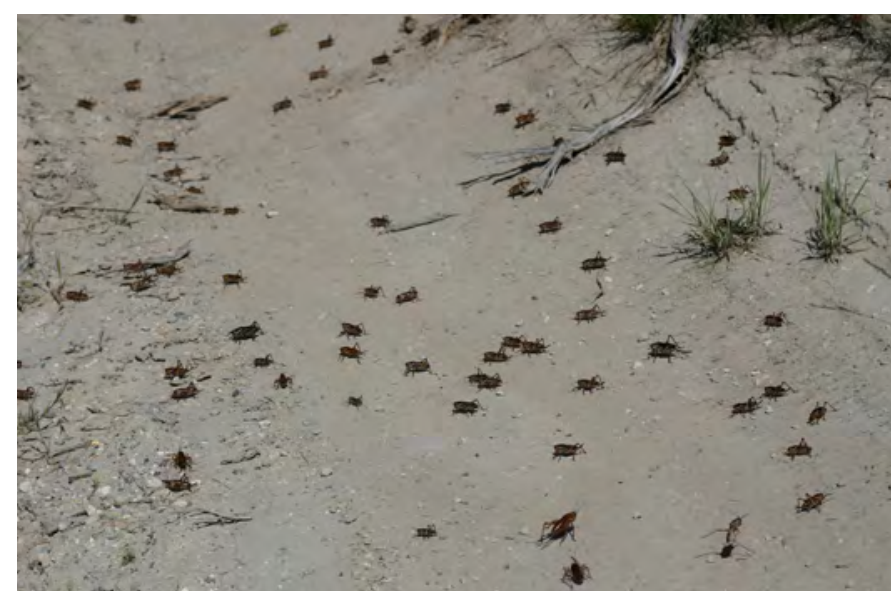

Figure 1. Mormon crickets on the road at Grouse Creek study site in May 2005, Utah (U.S. Geological Survey photograph by Tim Graham). pods, the food base for sensitive, rare, or threatened vertebrates, such as sage grouse and spotted frogs, will be depleted.

Studies on the Great Plains have shown diflubenzuron to have minimal impacts on nontarget arthropods and their vertebrate predators (Wilcox and Coffey, 1978; McEwen and others, 1996), reinforcing the decision to use diflubenzuron in a reduced agent-area treatment design (using less pesticide in alternating swaths) instead of carbaryl or malathion. Some nontarget arthropods were affected by diflubenzuron, at least in the short term, in some studies (Catangui and others, 2000; Smith and others, 2006). The generality of previous work has not been established. Information directly applicable to the environment of Utah's west desert is required for assessing potential impacts of diflubenzuron on nontarget arthropods in the Great Basin.

\section{Objectives}

This study was designed to help managers improve Orthoptera-control programs by increasing the understanding of how diflubenzuron affects both target and nontarget arthropods. The specific objectives of this study were to (1) compare aquatic and terrestrial arthropod community structure (abundance and species composition) in treated and untreated sites in the west desert to determine whether there were changes in either target or nontarget arthropod populations, (2) compare responses at three study areas to determine whether response was similar across the landscape, and (3) compare terrestrial and aquatic arthropod community structure over time at each study area following insecticide treatment. The study also yields valuable baseline data on both aquatic and terrestrial arthropod communities in west desert rangeland ecosystems.

\section{Scope}

Three areas of Utah's west desert — Grouse Creek, Ibapah, and Vernon - were chosen for 2005 sampling based on Orthoptera outbreaks in preceding years. However, in 2005, the only area significantly infested, and therefore sprayed with diflubenzuron, was Grouse Creek. We modified our objectives to account for the reduced control effort. We sampled for short-term effects of diflubenzuron at Grouse Creek; at the other two study areas, we tested for lag effects of diflubenzuron application by sampling in untreated zones and zones treated in 2004. Without prespray data or several years of postspray data, our analysis was limited. In addition, water bodies are rare in this semiarid environment; consequently, it was difficult to locate a large number of comparable types of aquatic systems within and outside the treated zone in a given study area. Topography also proved to be an issue, particularly at Vernon, for both terrestrial and aquatic sampling because the treatment zone was on the valley floor and sites outside of the treatment zone were approximately 60-65 m higher in elevation. 


\section{Study Area}

Grouse Creek (fig. 2), Ibapah (fig. 3), and Vernon (fig. 4) in Utah's west desert were chosen for sampling due to large Mormon cricket populations in previous years and large expected populations for 2005. Ibapah and Vernon had large Mormon cricket populations for a number of years but were not treated with diflubenzuron prior to 2004 (G. Abbott, Animal and Plant Health Service, written commun., 2007). Grouse Creek had not been treated before 2005. Patchy application of carbaryl bran bait in previous years was done in all three areas (G. Abbott, Animal and Plant Health Service, written com- mun., 2007), including some areas we considered untreated relative to diflubenzuron application for this study. Diflubenzuron was applied to the Grouse Creek treatment zone in May 2005. Grouse Creek is in the extreme northwestern part of the State. We sampled terrestrial sites in four vegetation associations (table 1) according to the Southwest Regional Gap analysis (Prior-Magee and others, 2007). Ibapah sites, near the Utah-Nevada border, were all in the same vegetation association, although there was some variability on the ground in abundance of different vegetation components. The Vernon study area, south of Vernon, Utah, was more diverse, encompassing five vegetation communities.
Figure 2. Grouse Creek study area with treated zone shaded; terrestrial (red) and aquatic (blue) sampling sites are shown within treated and untreated zones.

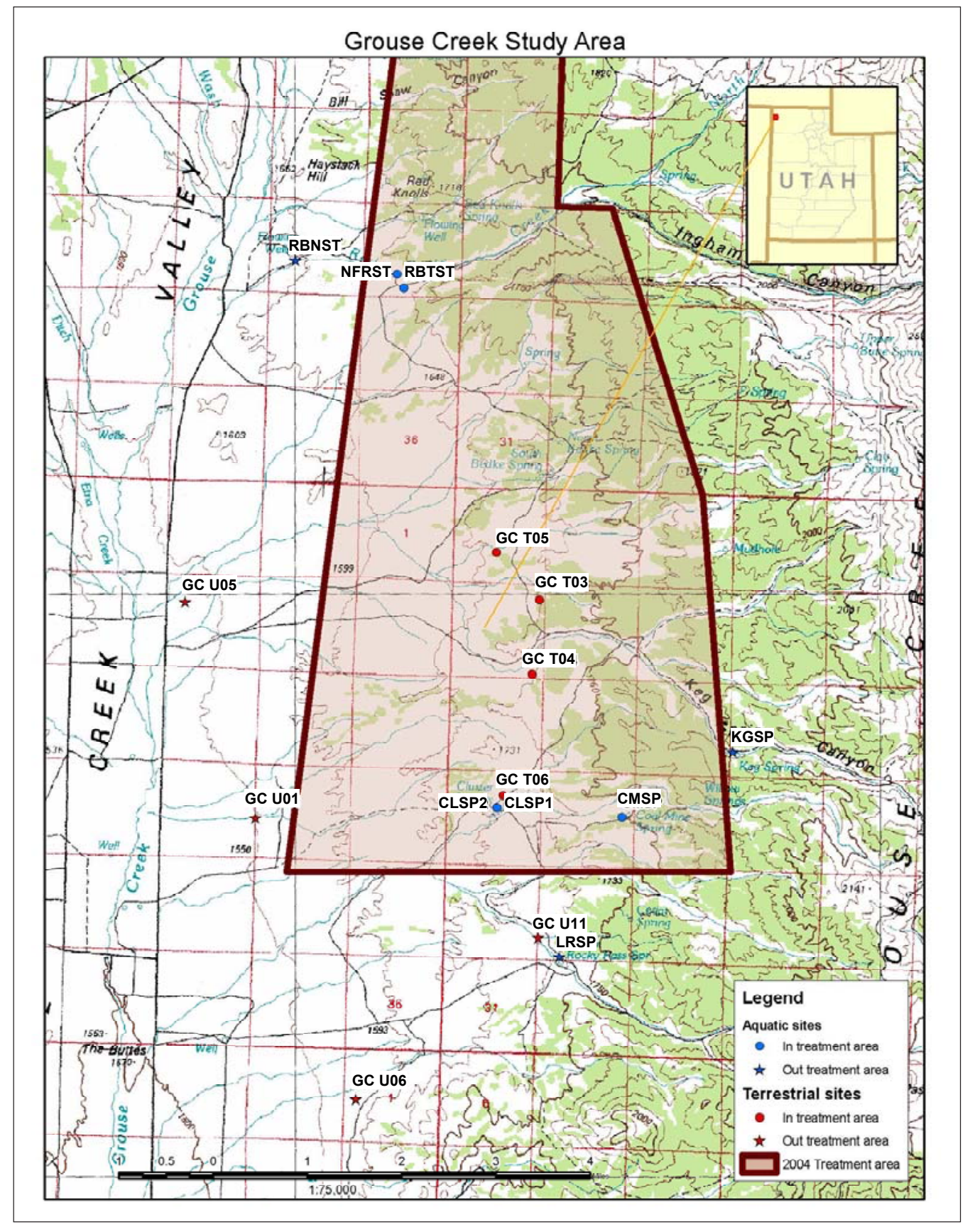




\section{Terrestrial Sampling}

\section{Study Sites}

Terms for the different spatial scales of this study were defined as follows: study area is defined as one of the three major geographic areas studied [that is, Grouse Creek (GC), Ibapah (IB) or Vernon (VE)]; treatment zone refers to the area within a study area that was treated $(\mathrm{T})$ or untreated $(\mathrm{U})$ with diflubenzuron (that is, treated zone, untreated zone); site refers to the individual locations sampled using pitfall traps within a treatment zone in a study area (for example, GC U06, IB T22, and VE U09). In 2005, Mormon cricket-control efforts were concentrated in the mountains east and west of Grouse Creek valley. We established four sites in the eastern Grouse Creek treatment zone; four untreated sites also were established to the west and south of this treated zone (fig. 5). At the other two study areas, Ibapah (fig. 6) and Vernon (fig. 7), we sampled both zones that had been treated with diflubenzuron in 2004 and adjacent untreated zones. Here we also established four pitfall sites in each of the treated and untreated zones. All pitfall sites were established at locations randomly

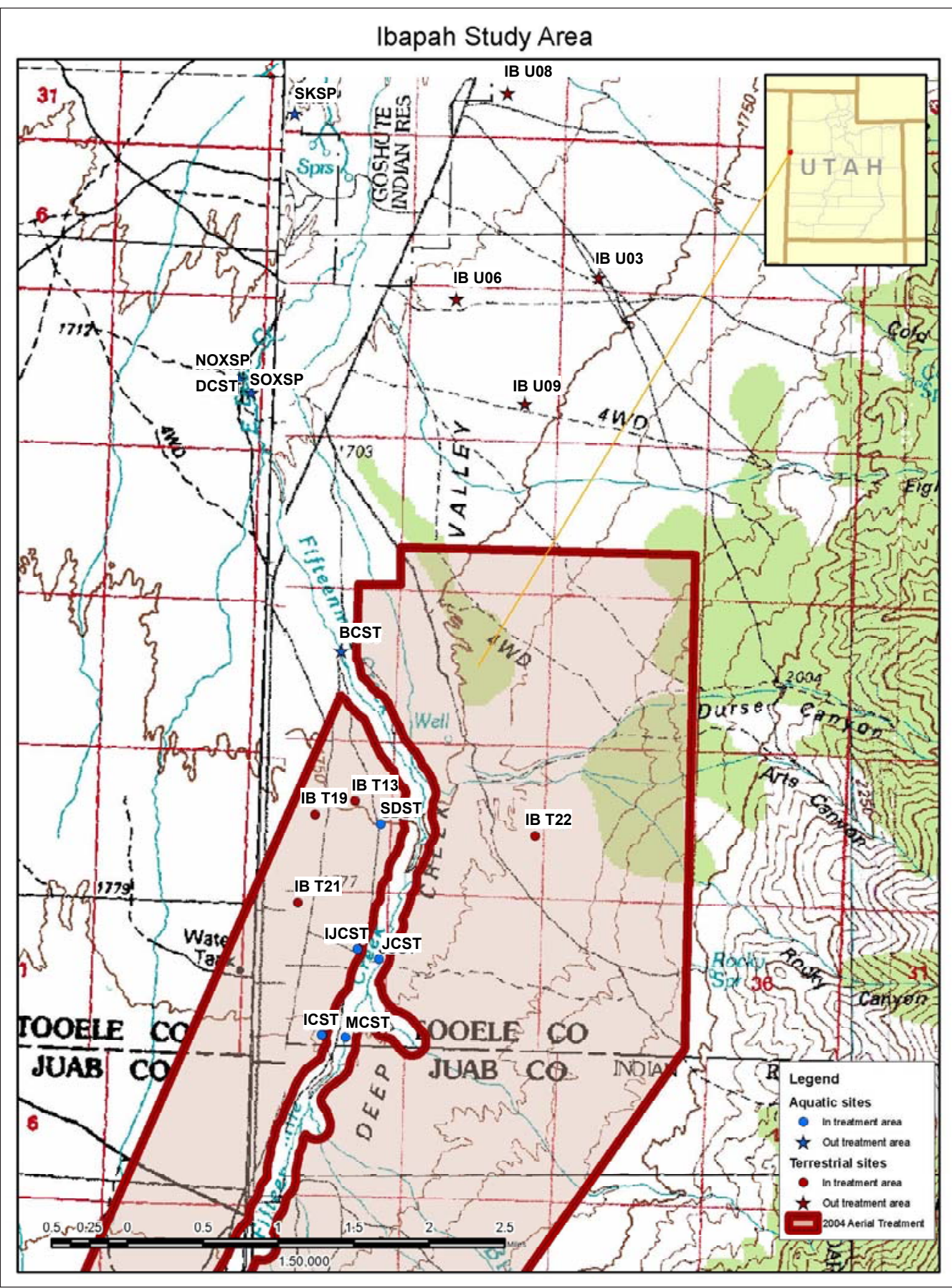

Figure 3. Ibapah study area with treated zone shaded; terrestrial and aquatic sampling sites are shown within treated zone and untreated zones. 
selected with a geographic information system. General site characteristics, site-code designations, and sampling dates are shown in table 1 .

\section{Sampling Design}

Terrestrial arthropods were sampled by using pitfall traps arranged in a pattern that allowed capture data to be used with DISTANCE software (Buckland and others, 2001) to estimate density of total arthropods and of individual taxa (Lukacs and others, 2004). Pitfall traps at each site were arranged to meet the assumptions of DISTANCE sampling, which are that all invertebrates on the center line are detected (that is, caught) and that distances from the center line are accurately measured. We used 60 traps at each site in the arrangement shown in figure 8 . This pattern was generated by using WebSim (Lukacs, 2001, 2002) to simulate a hazard-rate model of invertebrate captures that resulted in estimates with small confidence intervals, and matched trapping results in a pilot study of invertebrate pitfall trapping in Colorado (Lukacs, oral commun., 2005).
Figure 4. Vernon study area with treated zone shaded; terrestrial and aquatic sampling sites shown within treated zone and untreated zones.

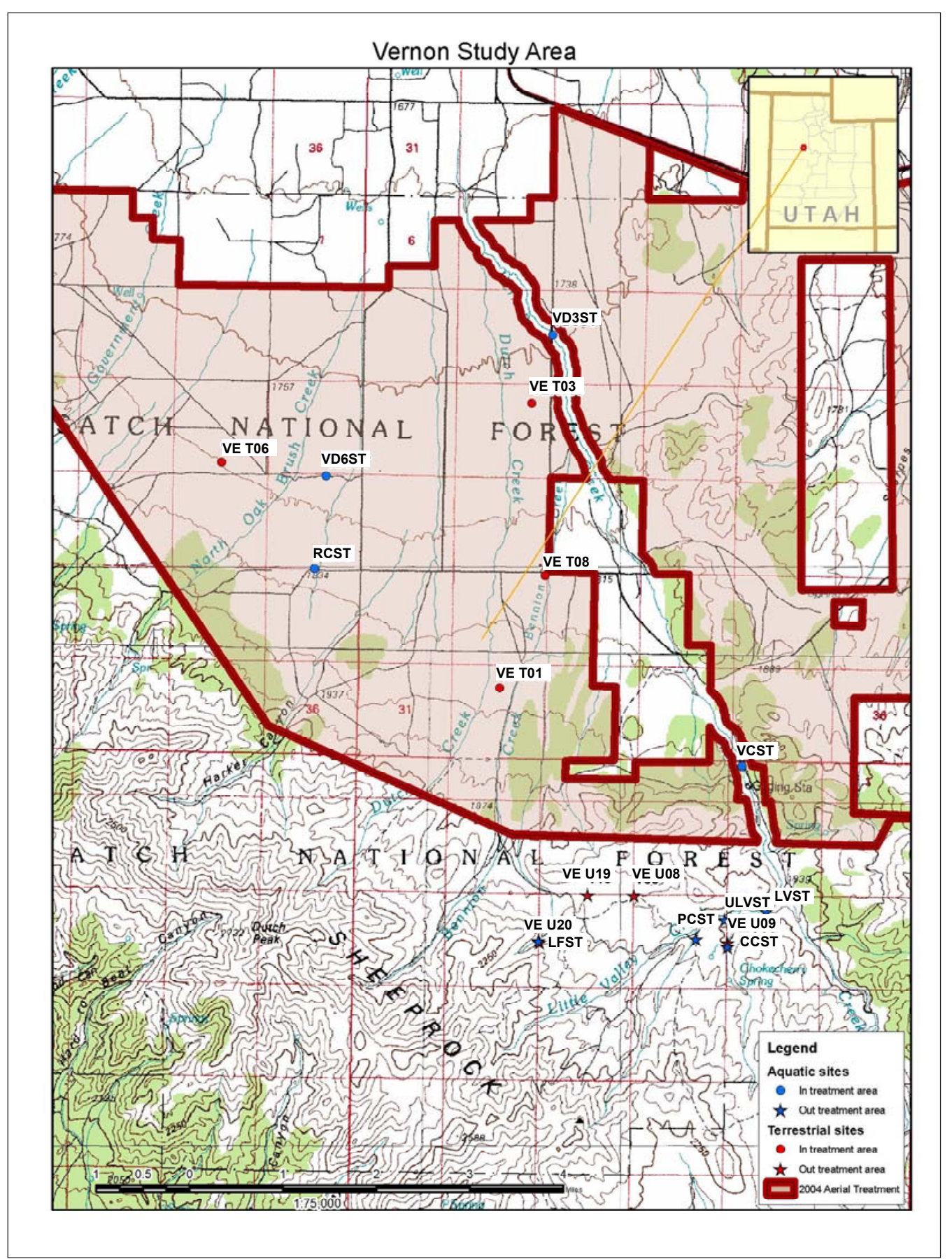


Table 1. Terrestrial site and sampling information, west desert study sites, Utah.

\begin{tabular}{|c|c|c|c|c|c|c|}
\hline Site code & $\begin{array}{l}\text { Treatment } \\
\text { zone }\end{array}$ & $\begin{array}{l}\text { Elevation, } \\
\text { in meters }\end{array}$ & GAP vegetation classification & Sample dates & Sample period & $\begin{array}{l}\text { Number of } \\
\text { days traps } \\
\text { were open }\end{array}$ \\
\hline \multicolumn{7}{|c|}{ Grouse Creek } \\
\hline \multirow[t]{2}{*}{ GC U01 } & Untreated & 1,549 & $\begin{array}{l}\text { Inter-Mountain Basin Mixed Salt Desert } \\
\text { Scrub }\end{array}$ & $6 / 3 / 2005$ & pre-treatment & 2 \\
\hline & & & & $6 / 20 / 2005$ & post-treatment & 4 \\
\hline \multirow[t]{2}{*}{ GC U05 } & Untreated & 1,542 & Invasive Perennial Grassland & $6 / 3 / 2005$ & pre-treatment & 2 \\
\hline & & & & $6 / 22 / 2005$ & post-treatment & 2 \\
\hline \multirow[t]{2}{*}{ GC U06 } & Untreated & 1,573 & $\begin{array}{l}\text { Inter-Mountain Basin Semi-Desert } \\
\text { Grassland }\end{array}$ & $6 / 6 / 2005$ & pre-treatment & 3 \\
\hline & & & & $6 / 21 / 2005$ & post-treatment & 4 \\
\hline \multirow[t]{2}{*}{ GC U11 } & Untreated & 1,669 & $\begin{array}{l}\text { Inter-Mountain Basin Big Sagebrush } \\
\text { Shrubland }\end{array}$ & $5 / 27 / 2005$ & pre-treatment & 2 \\
\hline & & & & $6 / 22 / 2005$ & post-treatment & 5 \\
\hline \multirow[t]{2}{*}{ GC T03 } & Treated & 1,705 & $\begin{array}{l}\text { Inter-Mountain Basin Big Sagebrush } \\
\text { Shrubland }\end{array}$ & $5 / 26 / 2005$ & pre-treatment & 2 \\
\hline & & & & $6 / 23 / 2005$ & post-treatment & 2 \\
\hline \multirow[t]{2}{*}{ GC T04 } & Treated & 1,701 & $\begin{array}{l}\text { Inter-Mountain Basin Big Sagebrush } \\
\text { Shrubland }\end{array}$ & $5 / 27 / 2005$ & pre-treatment & 3 \\
\hline & & & & $6 / 21 / 2005$ & post-treatment & 4 \\
\hline \multirow[t]{2}{*}{ GC T05 } & Treated & 1,665 & $\begin{array}{l}\text { Inter-Mountain Basin Big Sagebrush } \\
\text { Shrubland }\end{array}$ & $5 / 30 / 2005$ & pre-treatment & 4 \\
\hline & & & & $6 / 23 / 2005$ & post-treatment & 2 \\
\hline \multirow[t]{2}{*}{ GC T06 } & Treated & 1,665 & $\begin{array}{l}\text { Inter-Mountain Basin Big Sagebrush } \\
\text { Shrubland }\end{array}$ & $5 / 26 / 2005$ & pre-treatment & 2 \\
\hline & & & & $6 / 20 / 2005$ & post-treatment & 4 \\
\hline \multicolumn{7}{|c|}{ Ibapah } \\
\hline IB U03 & Untreated & 1,734 & $\begin{array}{l}\text { Inter-Mountain Basin Big Sagebrush } \\
\text { Shrubland }\end{array}$ & $7 / 14 / 2005$ & $\begin{array}{l}1 \text { year post- } \\
\text { treatment }\end{array}$ & 3 \\
\hline IB U06 & Untreated & 1,707 & $\begin{array}{l}\text { Inter-Mountain Basin Big Sagebrush } \\
\text { Shrubland }\end{array}$ & $7 / 15 / 2005$ & $\begin{array}{l}1 \text { year post- } \\
\text { treatment }\end{array}$ & 3 \\
\hline IB U08 & Untreated & 1,670 & $\begin{array}{l}\text { Inter-Mountain Basin Big Sagebrush } \\
\text { Shrubland }\end{array}$ & $7 / 14 / 2005$ & $\begin{array}{l}1 \text { year post- } \\
\text { treatment }\end{array}$ & 3 \\
\hline IB U09 & Untreated & 1,747 & $\begin{array}{l}\text { Inter-Mountain Basin Big Sagebrush } \\
\text { Shrubland }\end{array}$ & $7 / 15 / 2005$ & $\begin{array}{l}1 \text { year post- } \\
\text { treatment }\end{array}$ & 3 \\
\hline IB T13 & Treated & 1,756 & $\begin{array}{l}\text { Inter-Mountain Basin Big Sagebrush } \\
\text { Shrubland }\end{array}$ & $7 / 15 / 2005$ & $\begin{array}{l}1 \text { year post- } \\
\text { treatment }\end{array}$ & 3 \\
\hline IB T19 & Treated & 1,769 & $\begin{array}{l}\text { Inter-Mountain Basin Big Sagebrush } \\
\text { Shrubland }\end{array}$ & $7 / 15 / 2005$ & $\begin{array}{l}1 \text { year post- } \\
\text { treatment }\end{array}$ & 3 \\
\hline IB T21 & Treated & 1,784 & $\begin{array}{l}\text { Inter-Mountain Basin Big Sagebrush } \\
\text { Shrubland }\end{array}$ & $7 / 14 / 2005$ & $\begin{array}{l}1 \text { year post- } \\
\text { treatment }\end{array}$ & 3 \\
\hline IB T22 & Treated & 1,826 & $\begin{array}{l}\text { Inter-Mountain Basin Big Sagebrush } \\
\text { Shrubland }\end{array}$ & $7 / 15 / 2005$ & $\begin{array}{l}1 \text { year post- } \\
\text { treatment }\end{array}$ & 3 \\
\hline
\end{tabular}


Table 1. Terrestrial site and sampling information, west desert study sites, Utah—Continued.

\begin{tabular}{|c|c|c|c|c|c|c|}
\hline Site code & $\begin{array}{l}\text { Treatment } \\
\text { zone }\end{array}$ & $\begin{array}{l}\text { Elevation, } \\
\text { in meters }\end{array}$ & GAP vegetation classification & Sample dates & Sample period & $\begin{array}{l}\text { Number of } \\
\text { days traps } \\
\text { were open }\end{array}$ \\
\hline \multicolumn{7}{|c|}{ Vernon } \\
\hline VE U08 & Untreated & 2,082 & $\begin{array}{l}\text { Southern Rocky Mountain Montane- } \\
\text { Subalpine Grassland }\end{array}$ & $7 / 23 / 2005$ & $\begin{array}{l}1 \text { year post- } \\
\text { treatment }\end{array}$ & 3 \\
\hline VE U19 & Untreated & 1,879 & Great Basin Piñon-Juniper Woodland & $7 / 22 / 2005$ & $\begin{array}{l}1 \text { year post- } \\
\text { treatment }\end{array}$ & 3 \\
\hline VE U20 & Untreated & 2,117 & $\begin{array}{l}\text { Inter-Mountain Basin Montane Sagebrush } \\
\text { Steppe }\end{array}$ & $7 / 22 / 2005$ & $\begin{array}{l}1 \text { year post- } \\
\text { treatment }\end{array}$ & 3 \\
\hline VE T01 & Treated & 1,829 & Great Basin Piñon-Juniper Woodland & $7 / 21 / 2005$ & $\begin{array}{l}1 \text { year post- } \\
\text { treatment }\end{array}$ & 3 \\
\hline VE T06 & Treated & 1,801 & $\begin{array}{l}\text { Inter-Mountain Basin Big Sagebrush } \\
\text { Shrubland }\end{array}$ & $7 / 22 / 2005$ & $\begin{array}{l}1 \text { year post- } \\
\text { treatment }\end{array}$ & 3 \\
\hline VE T08 & Treated & 1,829 & Great Basin Piñon-Juniper Woodland & $7 / 21 / 2005$ & $\begin{array}{l}1 \text { year post- } \\
\text { treatment }\end{array}$ & 3 \\
\hline
\end{tabular}

Figure 5. Typical terrestrial site at Grouse Creek study site, Utah, showing pitfall traps (U.S. Geological Survey photograph by Tim Graham).

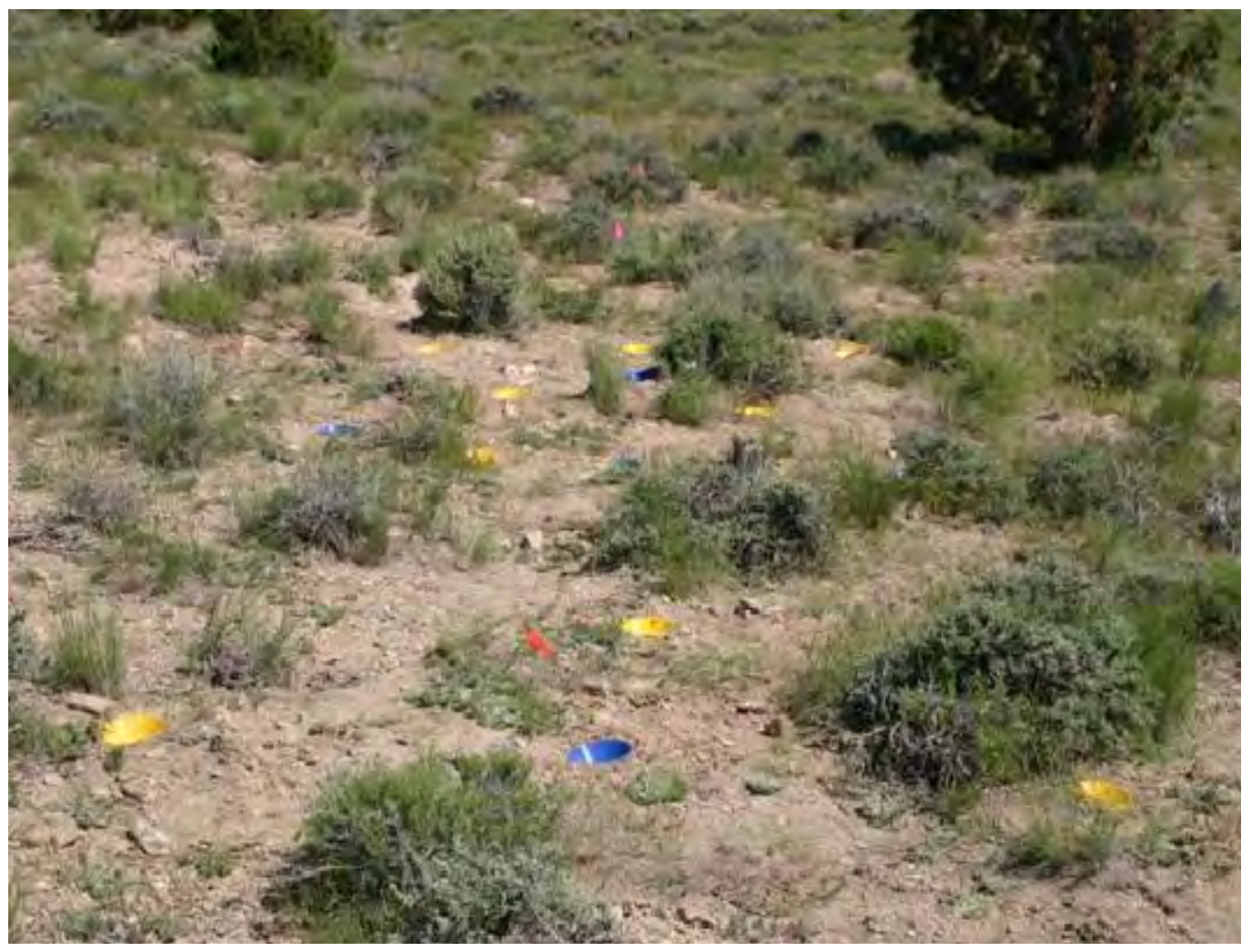



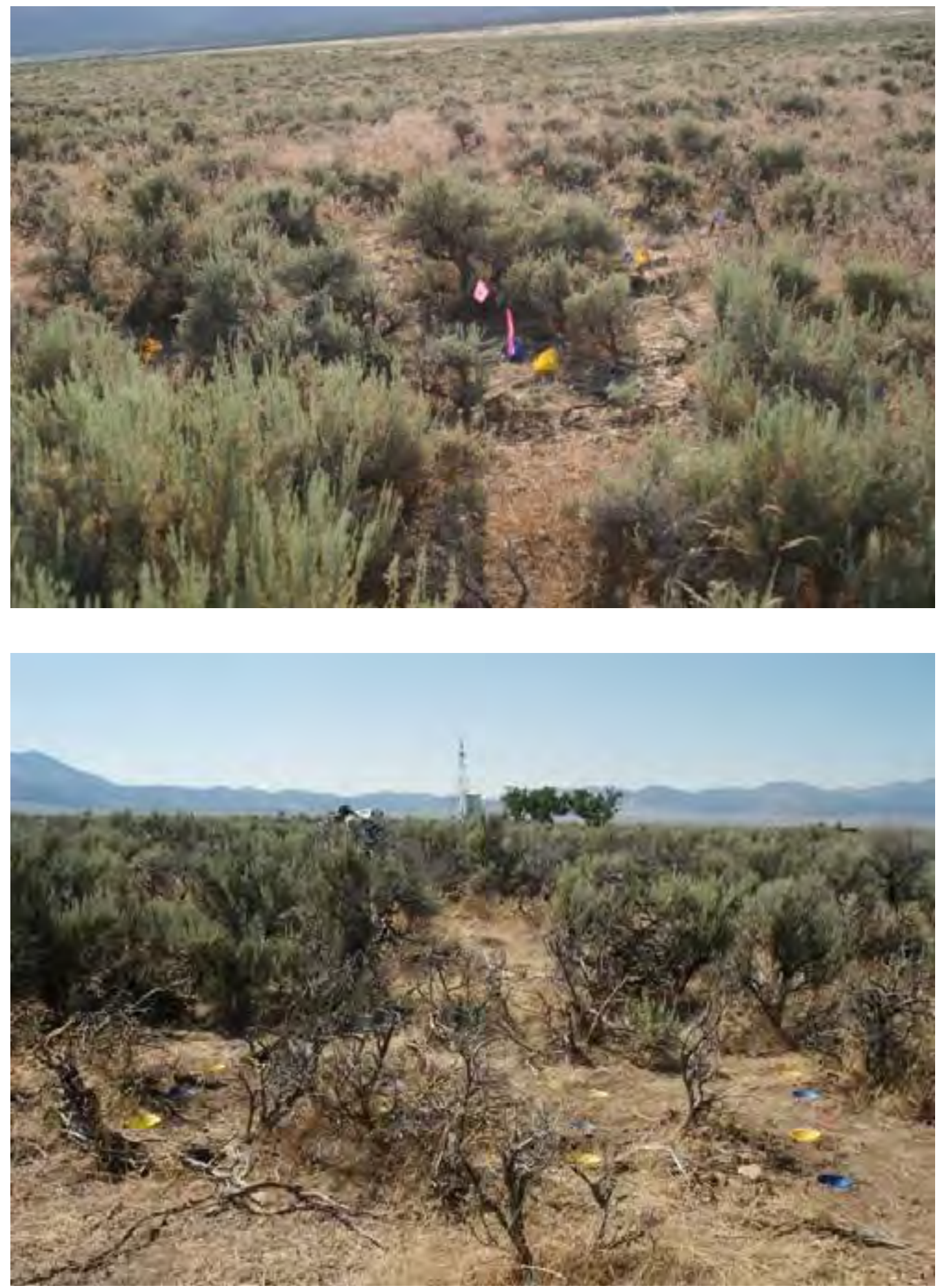

Figure 6. Typical terrestrial site at Ibapah study site, Utah (U.S. Geological Survey photograph by Tim Graham).
Figure 7. Typical terrestrial site at Vernon study site, Utah, showing pitfall traps (U.S. Geological Survey photograph by Becky Close).

\section{Sample Collection and Processing}

Pitfall traps were placed by carefully measuring and marking correct locations with flags, then digging in the traps (fig. 9). Pitfall traps were constructed as described by New (1998). For each trap, a 1.5-L plastic jar was buried below ground level and a $500-\mathrm{mL}$ cup containing $125 \mathrm{~mL}$ of soapy water was placed in the jar. A 15 -cm-diam funnel was placed over the jar, centered over the cup, with the top of the funnel at ground level.
At Grouse Creek, we sampled in late May/early June, just prior to application of diflubenzuron in both the zone to be treated and in the zone to remain untreated (pre-treatment samples). Traps at all sites in both treated and untreated zones were opened again in late June, about 3 weeks after diflubenzuron application (post-treatment samples). By comparing treated and untreated zones before and after treatment, differences between pre- and post-treatment communities associated with the phenology of the arthropods can be separated from those changes that may be due to exposure to diflubenzuron. 


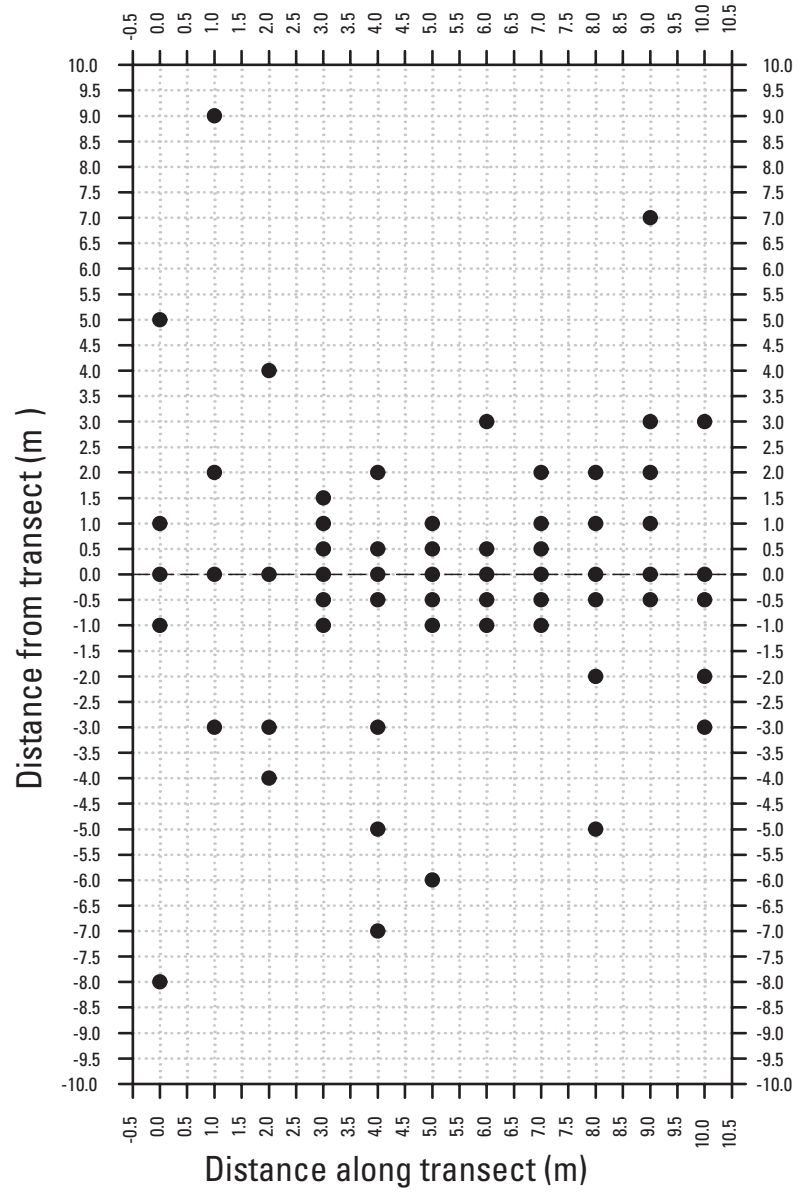

Figure 8. Arrangement of pitfall traps at each terrestrial arthropod sampling site of the study.
Ibapah and Vernon sampling occurred in July 2005, roughly a year following treatment of the treated zones; there was no temporal component to the study in these two areas.

Traps were kept open from 2 to 5 days (table 1); the time period eventually was standardized at 3 days, but different timeframes were used in early sampling periods due to logistical constraints.

Each trap's contents were washed in the field through a $0.5-\mathrm{mm}$ mesh net three times; everything remaining in the net was placed in a $35-\mathrm{mL}$ vial containing about $25 \mathrm{~mL}$ isopropyl alcohol (fig. 10). A paper label with site, date, and trap number was placed inside each vial, and a stick-on label with the same information was affixed to the outside of each vial. Vials were kept in the shade in the field, as cool as possible, and stored at room temperature once they were returned to the lab.

\section{Sample Sorting and Identification}

All terrestrial invertebrates were sorted to order. Specimens in the orders Hemiptera and Orthoptera were identified to family; ants (Formicidae) were identified to genus (fig. 11). Taxa were identified following Triplehorn and Johnson (2005), and we followed the taxonomic nomenclature of this source (that is, the order Hemiptera includes Heteroptera and the Homoptera; Thysanura has been split into Microcoryphia and Thysanura). Differences in abundance, or presence/absence of particular taxa that correlated with treatment patterns, were used to identify potential indicator species.

\section{Data Analysis}

To allow comparisons among individual sites, treatmentzones, and study-areas, data are reported as numbers per day

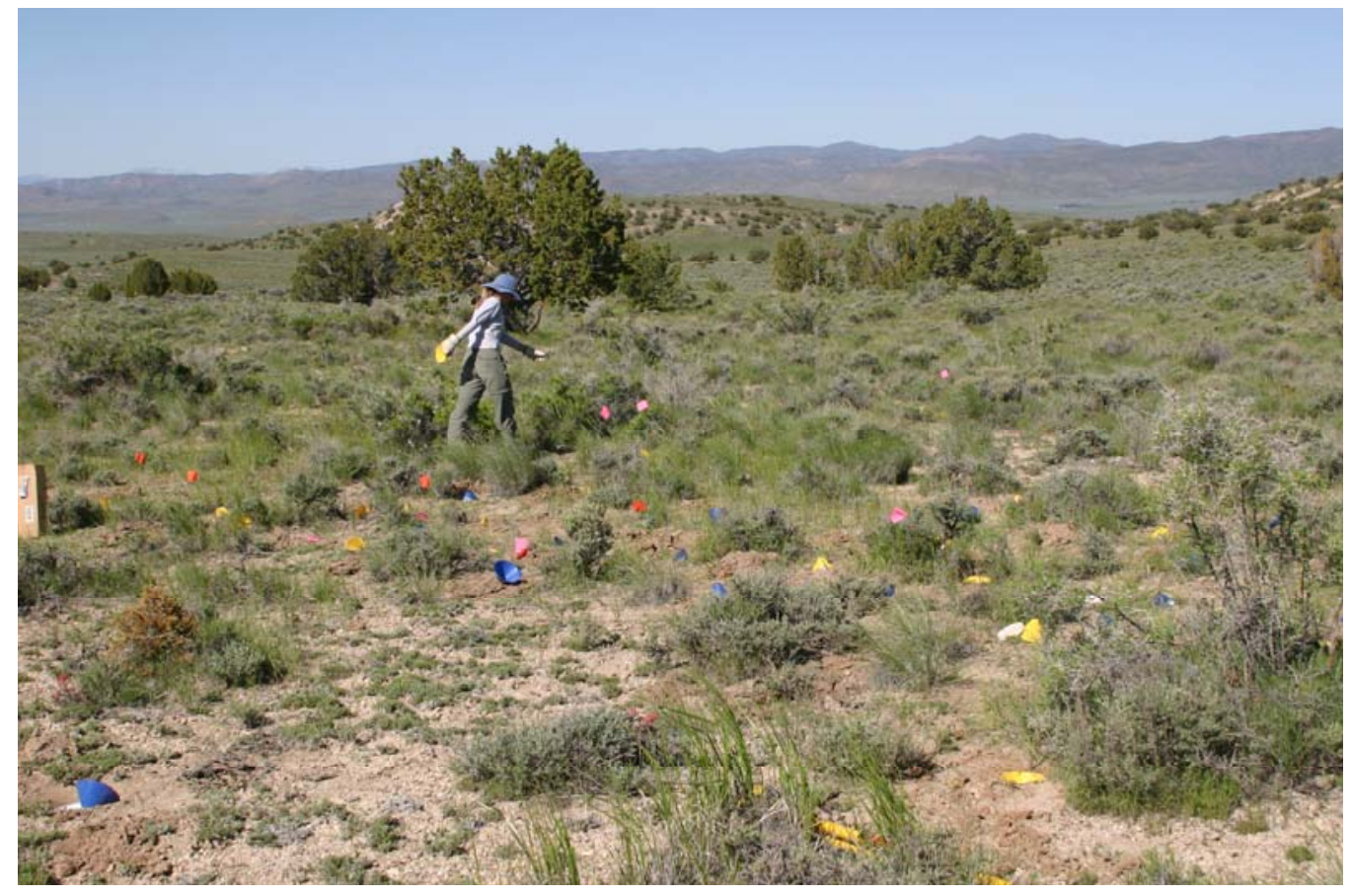

Figure 9. Putting in pitfall traps (U.S. Geological Survey photograph by Tim Graham). 


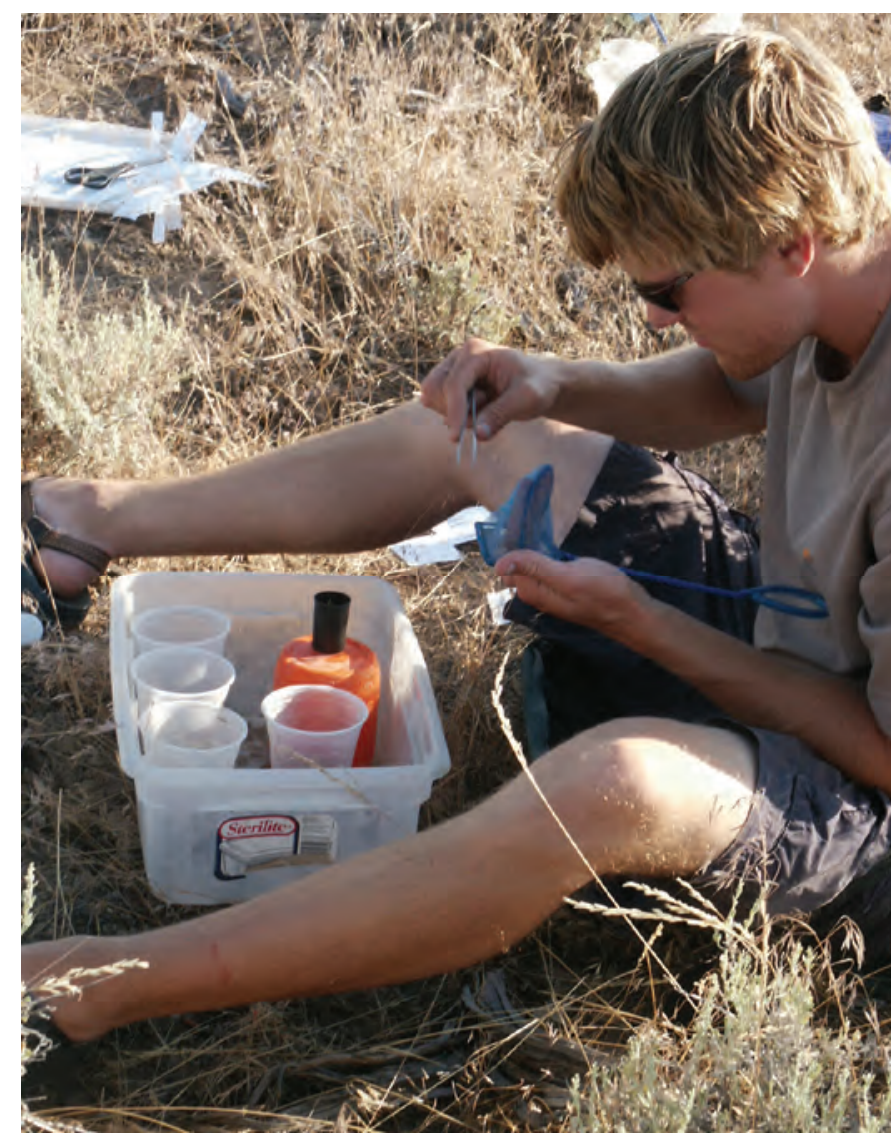

Figure 10. Processing terrestrial arthropods from pitfall trap in the field (U.S. Geological Survey photograph by Becky Close).

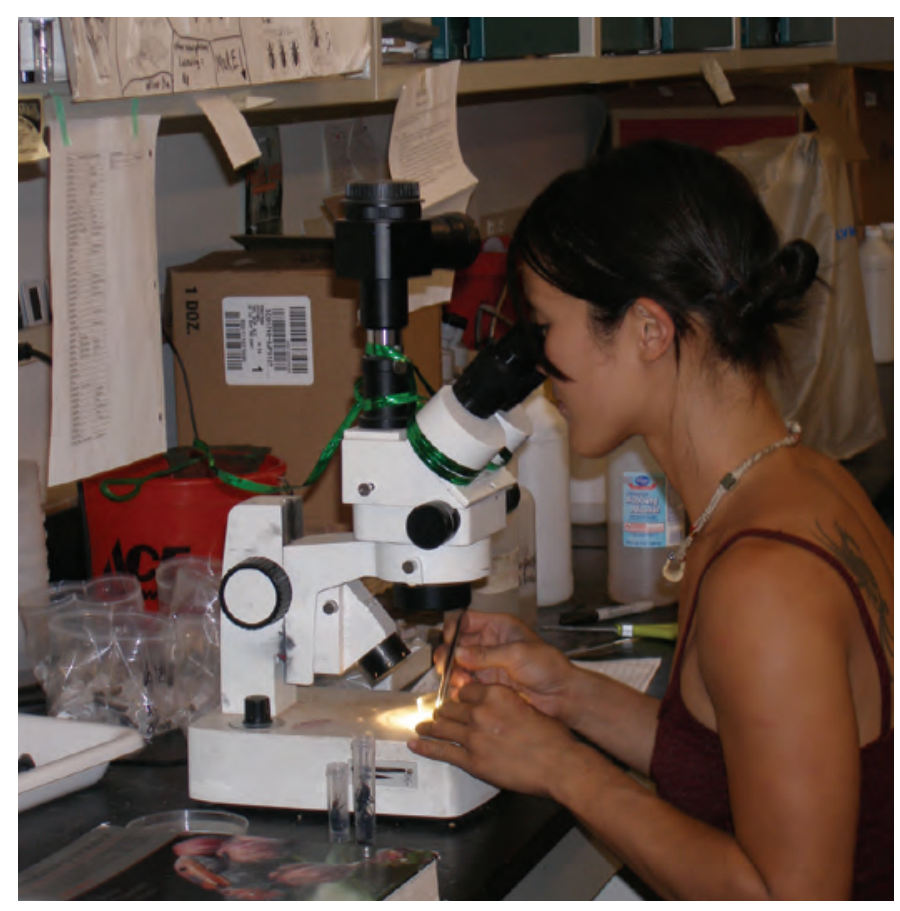

Figure 11. Sorting pitfall trap samples, removing debris, and identifying specimens to order (U.S. Geological Survey photograph by Tim Graham). (abundance) by taxon, and as relative abundance. Because traps were not kept open for the same number of days during all sampling events, all arthropod numbers were adjusted to average number per day by dividing the number of individuals (both total arthropods and individual taxa) caught in each trap by the number of days the traps at that site were open. Abundance data of terrestrial insects and other arthropods in treated versus untreated zones within a study area were tested for normality and equal variance, then compared using t-tests or Mann-Whitney rank sum tests, using SigmaStat (Systat, 2004). Statistical significance was assigned at $\alpha<0.05$; however, several of the observed differences in abundance were large, indicating the potential for biological significance even when statistical tests did not show them to be significant at $\alpha=0.05$. More sampling will tell whether these effects are real (they are masked by high variability, given our sample sizes); for the record, we note these cases with $\alpha<0.20$. Data used for nonmetric multidimensional scaling (NMS) consisted of the average number of individuals per day per taxon for each sampling event. NMS was performed in PC-ORD (McCune and Mefford, 2005) using Sorensen's distance measure. Fifty iterations were run with the data, then 250 iterations of a Monte Carlo test were used to estimate the best-fit (leaststress) solution.

\section{Terrestrial Results}

In May, June, and July 2005, 1,920 pitfall traps were set at the three study areas. More than 124,000 specimens have been identified to order. The total number of arthropods caught at a single site ranged from 853 at GC T06 (pre-treatment collection) to 36,043 at GC U05 (post-treatment collection). Relative abundance of the 13 orders varied considerably in space and time. The most common taxa were typically Diptera (flies), Hemiptera (true bugs), and Formicidae (ants), with Araneae (spiders), non-ant Hymenoptera (bees and wasps), and Orthoptera (grasshoppers, crickets, and such) fairly common at some sites. The three study areas had very different communities. Additionally, the variability among sites at each study area, even among the "replicate" sites of treated or untreated zones, was considerable. Few indications of the short-term effect of diflubenzuron at Grouse Creek on the relative abundance of any taxon except the Orthoptera (the object of control efforts) were discernible.

\section{Comparison of Proportional Abundance}

\section{Grouse Creek}

Flies were most abundant at the Grouse Creek untreated sites in late May and early June, with ants codominant at GC U11 and GC U06 (fig. 12). Spiders, beetles, bees, wasps, 
Hemiptera, and Lepidoptera also were common at one or more sites. By late June, communities at all sites had changed dramatically. At three sites, Hemiptera were by far the most abundant taxon. Ants and flies were still common at most sites but proportionately less abundant given the increase in numbers of Hemiptera. Spiders and Orthoptera increased at GC U11.

Hemiptera, Diptera, and ants were the most abundant groups at treated sites of Grouse Creek prior to treatment. The three groups accounted for more than 70 percent of all the arthropods caught at the four sites (fig. 13). GC T04 had the lowest proportion of Hemiptera, the highest proportion of ants, and larger numbers of beetles and Orthoptera than at the other sprayed sites prior to treatment. GC T04 had the most Mormon crickets during sampling in late May and early June.

After treatment, Hemiptera were much more abundant at the treated sites, showing a pattern similar to that of untreated sites. Ants and flies accounted for most of the other captures. Numbers of Orthoptera declined following treatment, as expected, showing the largest decline at GC T04. Most differences between pre- and post-treatment communities at the treated sites were similar to the changes observed among the untreated sites, indicating that the differences were likely due to seasonal changes, not treatment effects.
Figure 12. Proportional representation of taxa at the four sites in the Grouse Creek untreated zone. $A$, Pretreatment communities in late May or early June. $B$, Post-treatment communities in late June.

\section{$\boldsymbol{A}$}
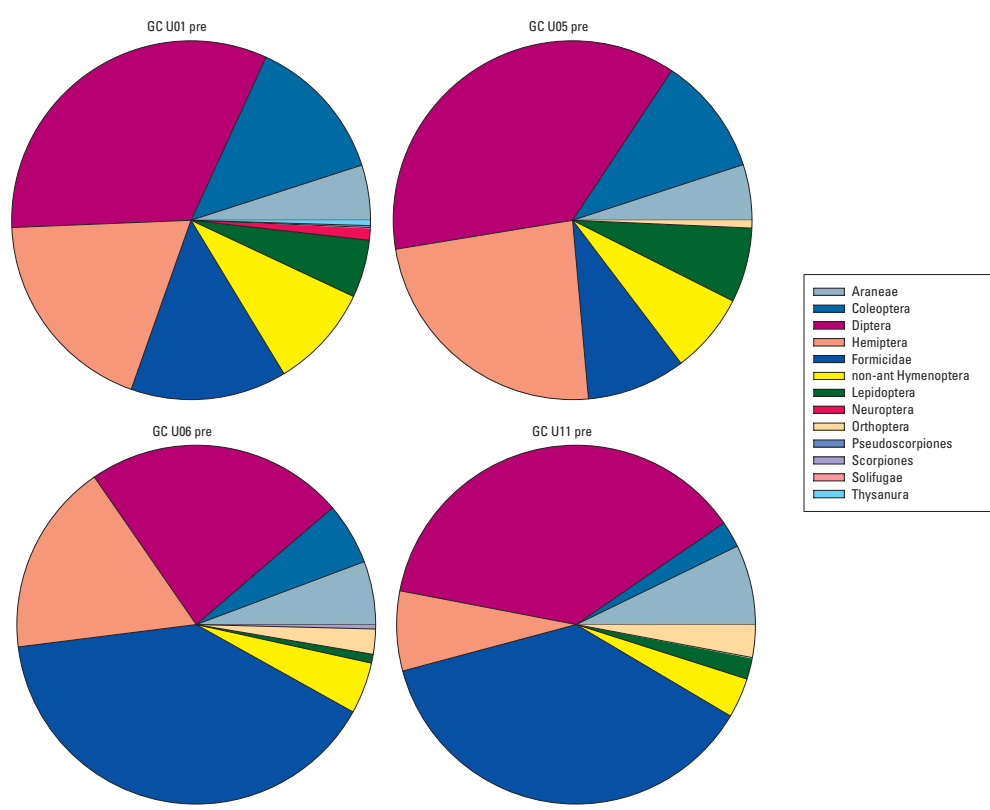

$\boldsymbol{B}$
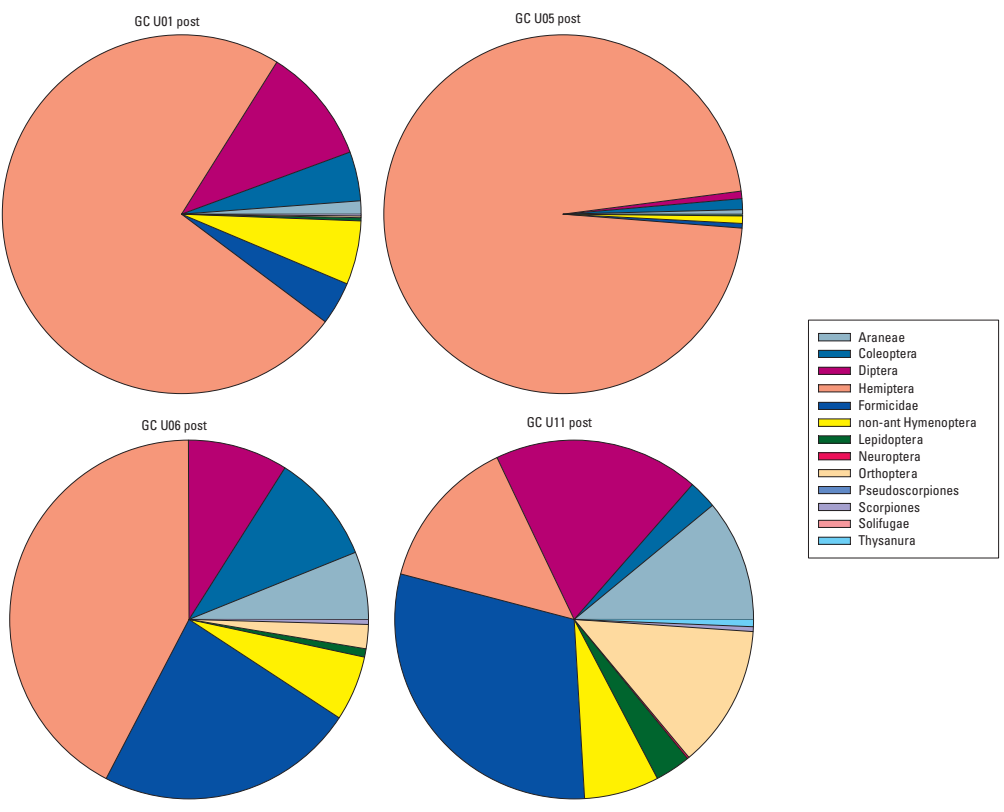


\section{Ibapah}

Ibapah sites were sampled only once, in mid-July 2005 (table 1). All communities had large Hemipteran components (fig. 14). Two sites, one treated (IB T13, 68 percent) and one untreated (IB U08, 92 percent), were heavily dominated by Hemiptera. Ants and flies also were abundant at all Ibapah sites; spiders were more prevalent than flies in traps at IB T19 and IB T22 (both treated in 2004). Flies were less common at Ibapah than at Grouse Creek, both in treated and untreated sites. Ants dominated all sites if Hemiptera were excluded from the dataset, constituting more than half the individuals at each site. Spider abundance also became more apparent if Hemiptera were excluded.

\section{Vernon}

Vernon was sampled only once in July 2005. At three of four untreated sites and three of four treated sites, about 25-40 percent of all the arthropods caught were Hemiptera; fewer than 15 percent of the arthropods caught at the other two sites (VE U20 and VE T01) were Hemiptera (fig. 15). Compared to Ibapah and Grouse Creek, Hemiptera and flies at Vernon were proportionately less abundant, and the Hymenoptera were relatively more abundant. Specifically, ants and the combined bee and wasp fractions of the Hymenoptera were better represented at Vernon. The non-ant Hymenoptera were more abundant at the untreated sites than

\section{$\boldsymbol{A}$}
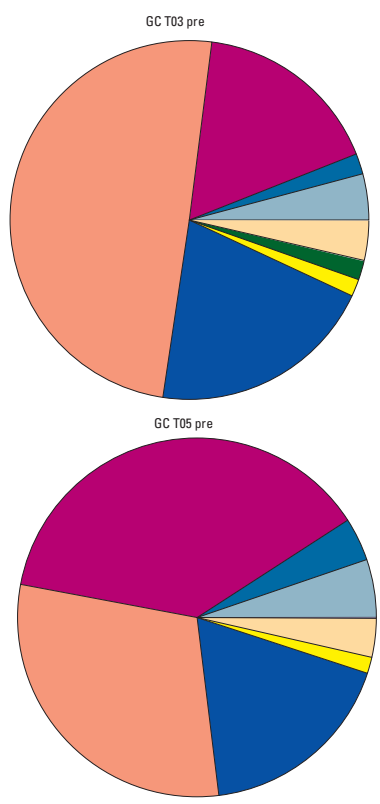

$\boldsymbol{B}$
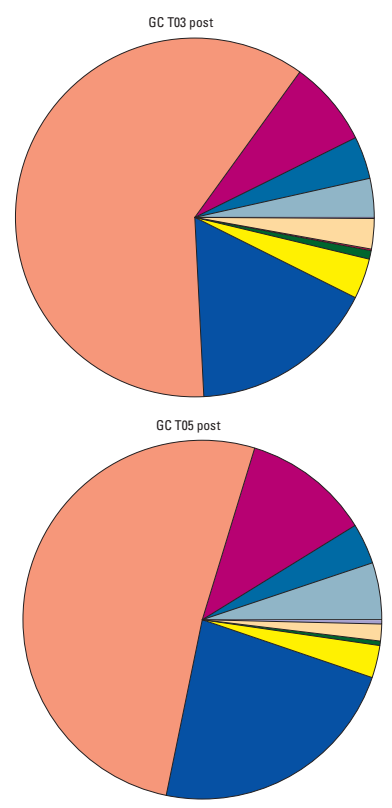

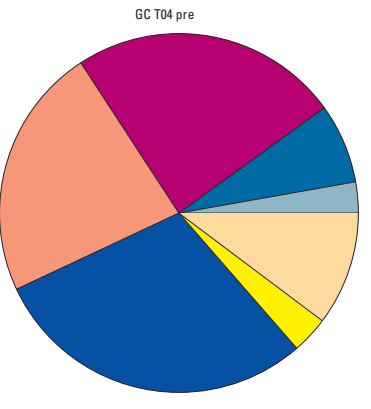

GC To6 pre
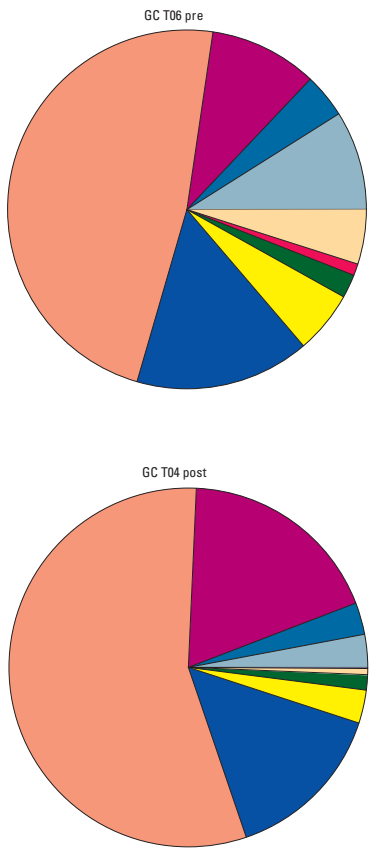

GC T06 post

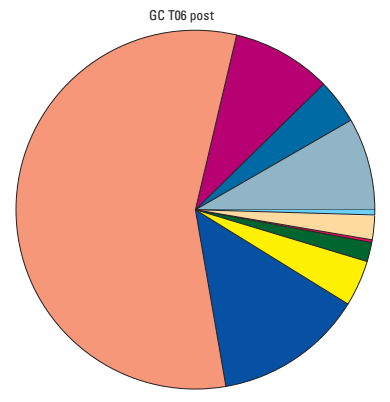

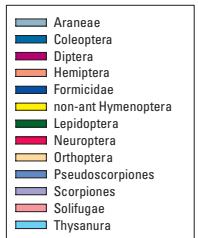

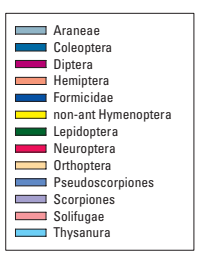

Figure 13. Proportional representation of taxa at the four sites in the Grouse Creek treated zone. $A$, pretreatment communities in late May and early June. $B$, Post-treatment communities in late June. 
at the treated sites, although there was no statistical difference in proportional abundance.

\section{Comparisons of Abundance by Orders in Treated and Untreated Zones}

Average abundance (numbers per day) for each taxon was calculated for the four sites within a treatment zone in each study area (fig. 16). A t test was used if the data passed normality and equal variance tests; the test statistic is represented as a t. If data failed normality or equal variance tests, compari- sons were made with the Mann-Whitney rank sum test; the test statistic is represented as $\mathrm{T}$.

Within each study area, abundance for each taxon in the treated zone was compared to abundance in the untreated zone. Data from different study areas were not compared to each other. At Grouse Creek, we also tested whether changes in arthropod abundance following application of diflubenzuron were related to the insecticide, or merely to phenology (seasonal changes in species composition) of the arthropod community. This test was conducted in two ways; the first approach was to compare average abundance before and after treatment within each treatment zone (for example, GC U pre-
Figure 14. Proportional representation of taxa at the eight Ibapah sites. Communities in the untreated $(A)$ and treated $(B)$ zones.

\section{$\boldsymbol{A}$}
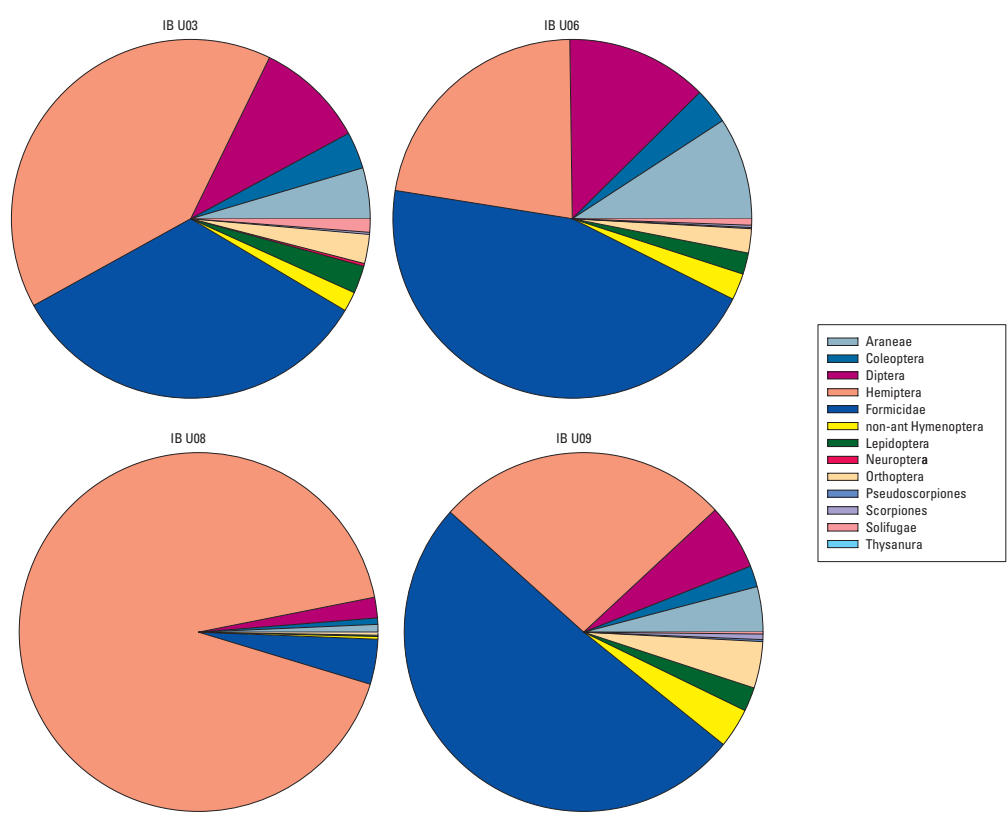

$\boldsymbol{B}$
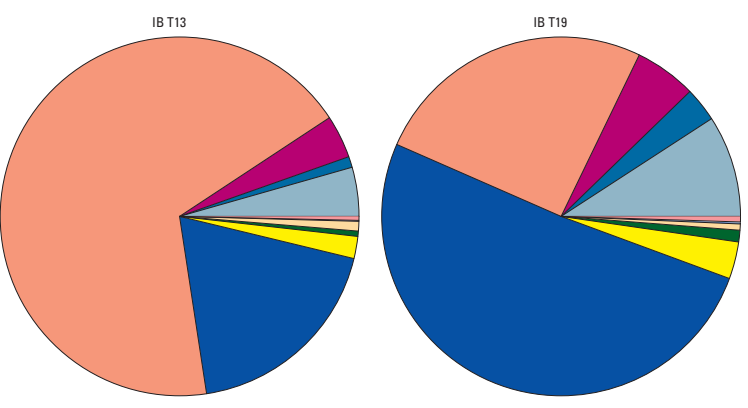

B T 21
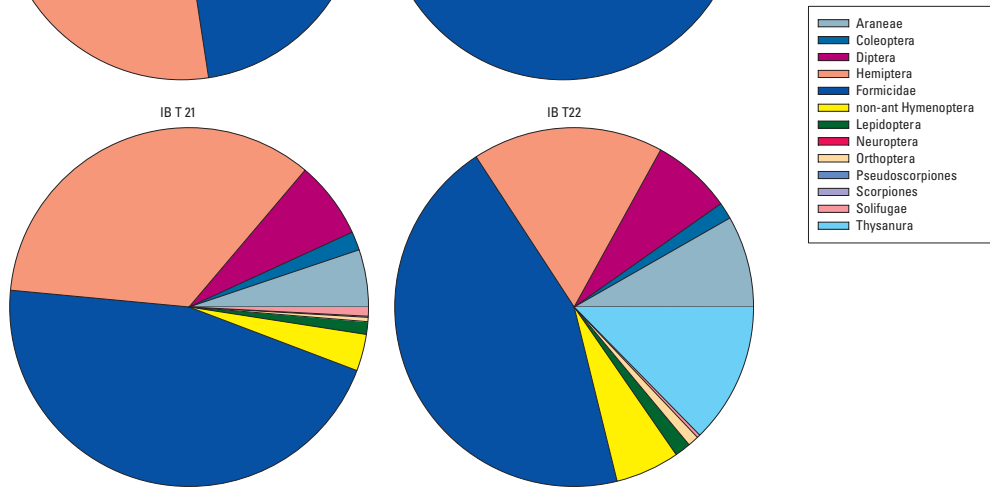
treatment compared to GC U post-treatment, and GC T pretreatment compared to GC T post-treatment). Significant differences for a given taxon in pre- and post-treatment numbers in the treated zone were interpreted as indicating a possible effect of diflubenzuron application. The second approach was to compare taxon abundance in the sprayed and unsprayed zones prior to treatment and again with the data collected 3 weeks after treatment. If there were no differences prior to treatment but treated and untreated average taxon abundance differed following treatment, we assumed diflubenzuron affected that taxon.

\section{Grouse Creek}

\section{Pre- versus Post-Treatment Changes in Untreated Zone}

Most taxa exhibited an increase in abundance from preto post-treatment sampling in the unsprayed zone at Grouse Creek (fig. $16 A-L)$. Spiders $\left(T_{\text {d.f. } 6}=10 ; P=0.029\right)$, non-ant Hymenoptera $\left(T_{\text {d.f. } 6}=10 ; P=0.029\right)$, and total arthropods $\left(T_{d . f .6}=10 ; P=0.029\right)$ were significantly more abundant in

\section{$\boldsymbol{A}$}
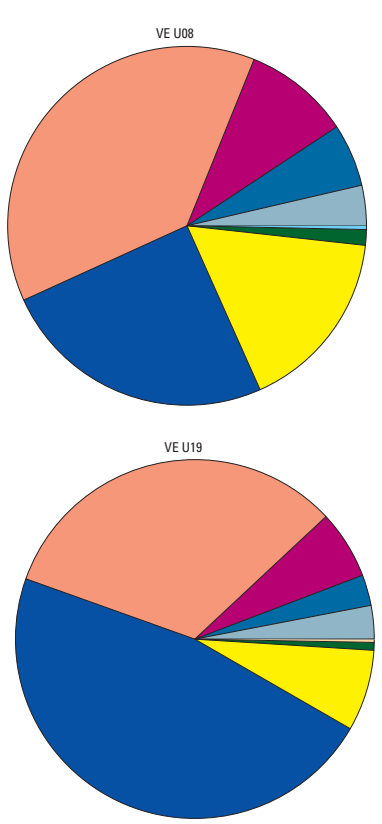

$\boldsymbol{B}$
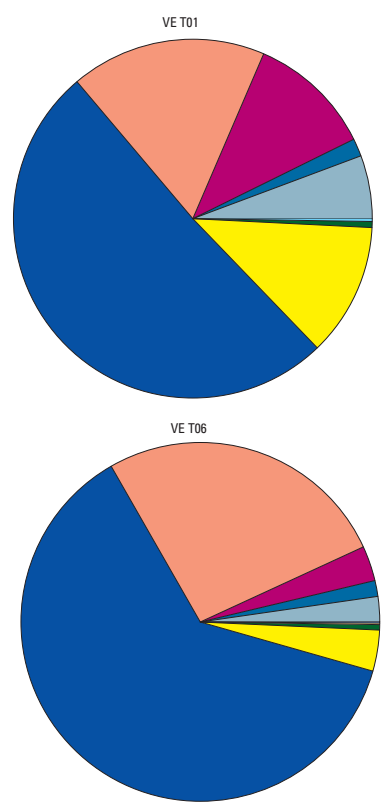
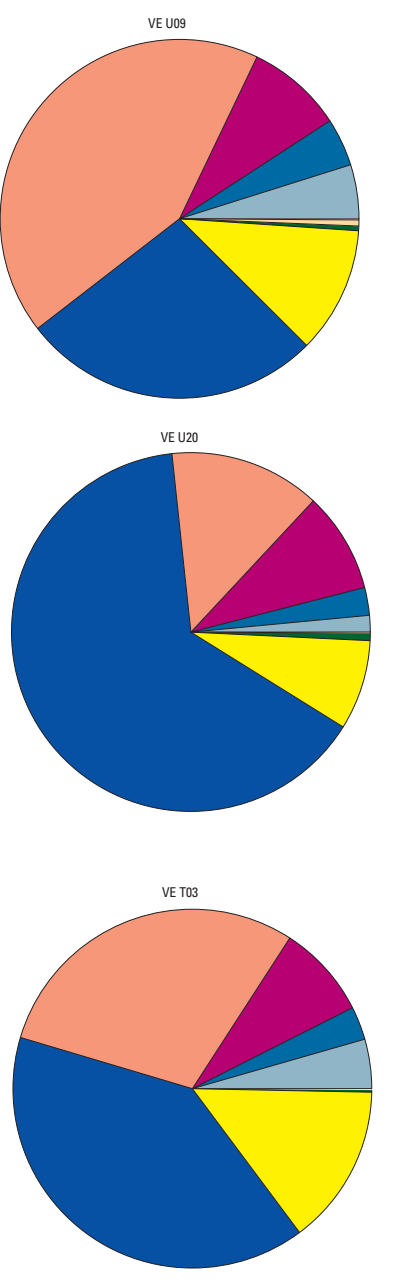

VE Tо8

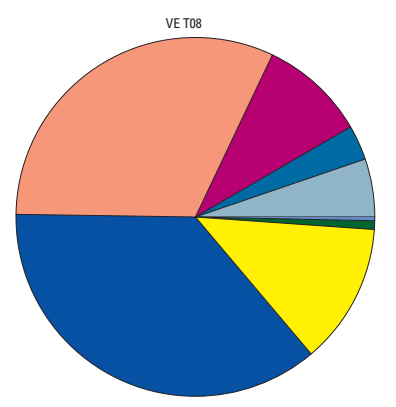

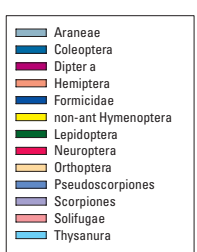

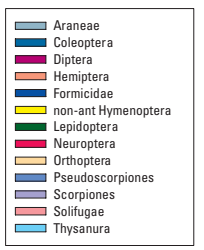

Figure 15. Proportional representation of taxa at the eight Vernon sites. Communities in the untreated $(A)$ and treated $(B)$ zones. 
$\boldsymbol{A}$

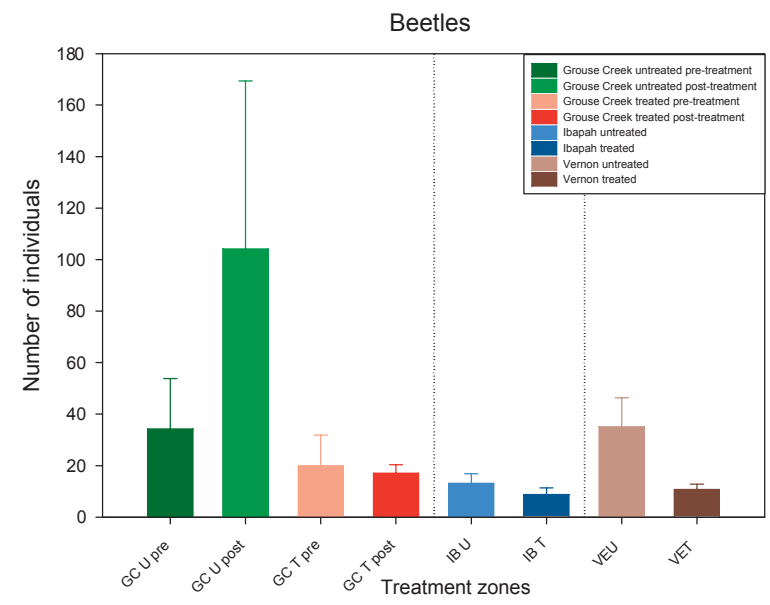

$\boldsymbol{B}$

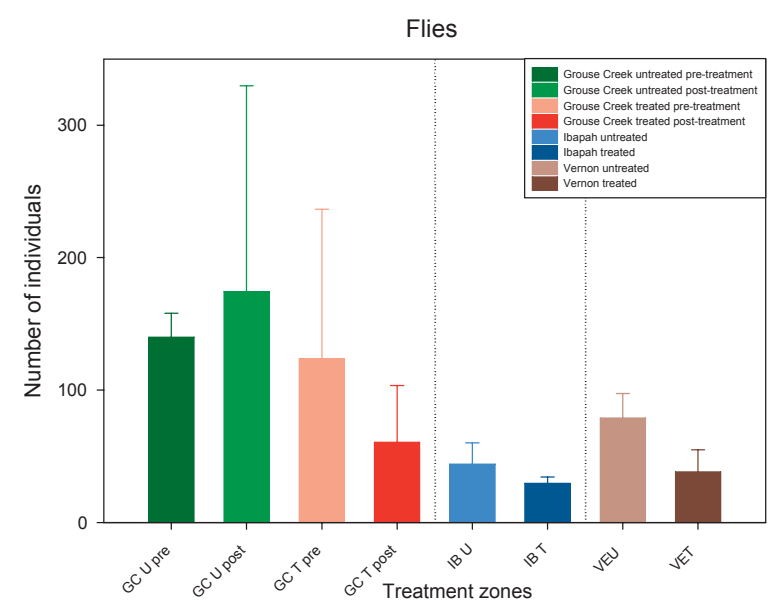

C

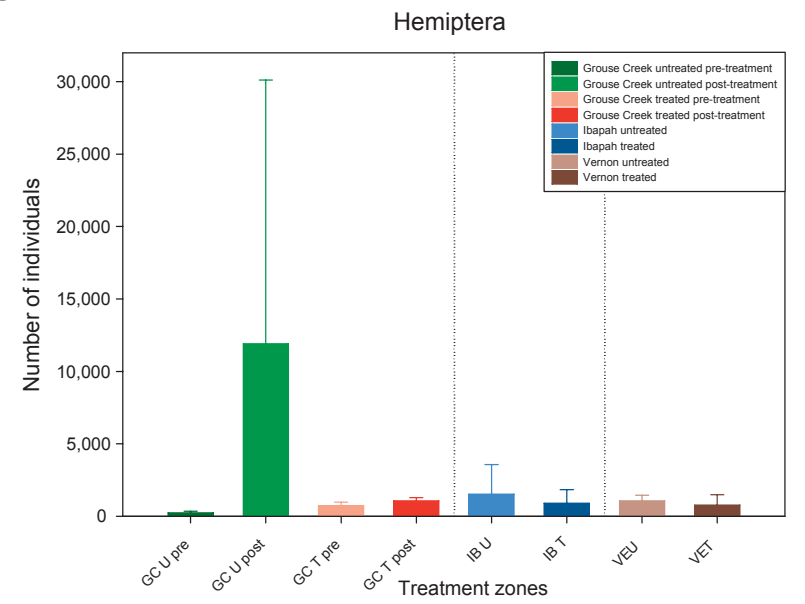

D

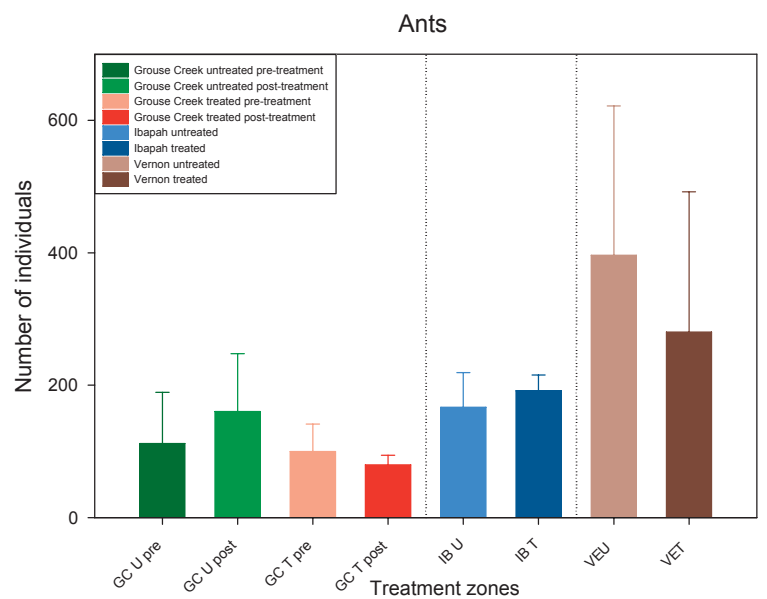

$\boldsymbol{E}$

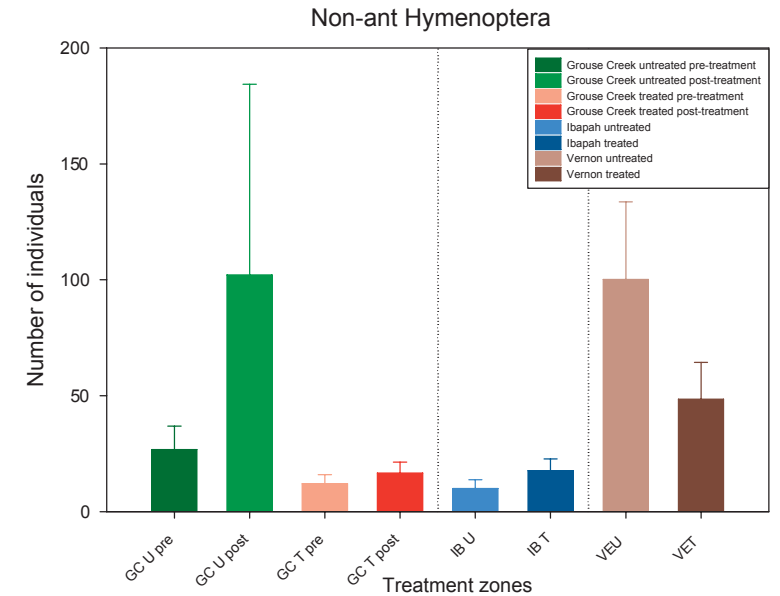

$\boldsymbol{F}$

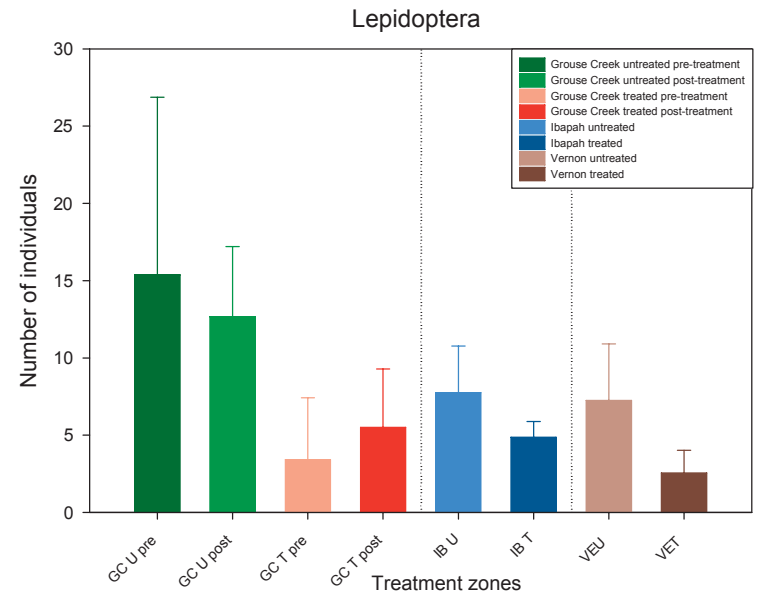

Figure $16 \mathrm{~A}-\mathrm{L}$. Average number of individuals (by taxon) in untreated (GC U pre- and post-treated, IB U, VE U) and treated (GC T preand post-treated, IB T, VE T) zones at the three study areas. 
G

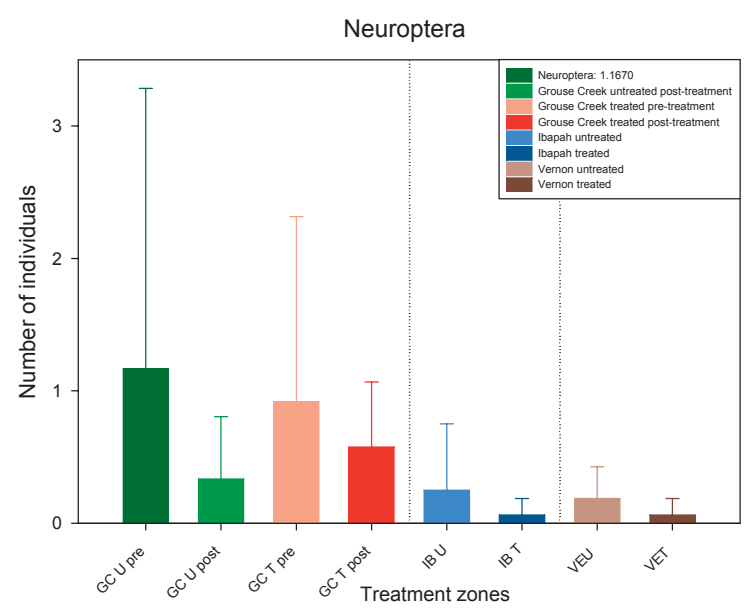

$\boldsymbol{H}$

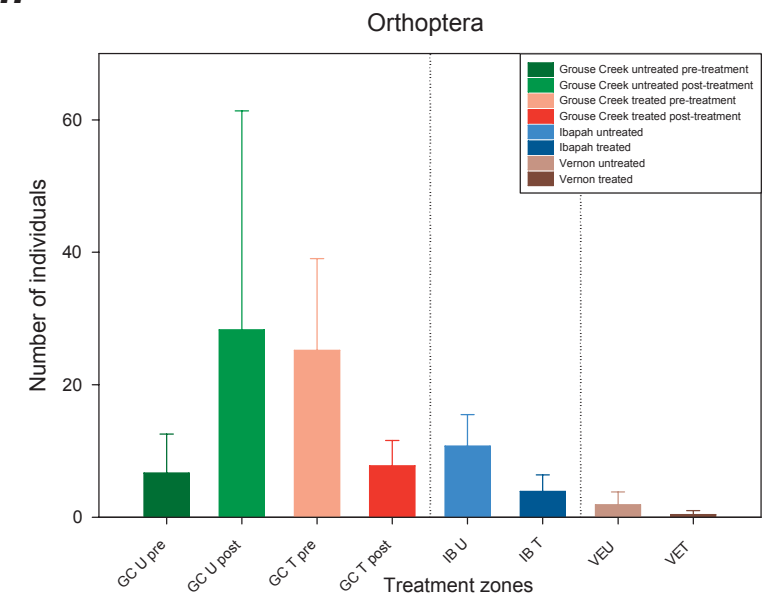

I

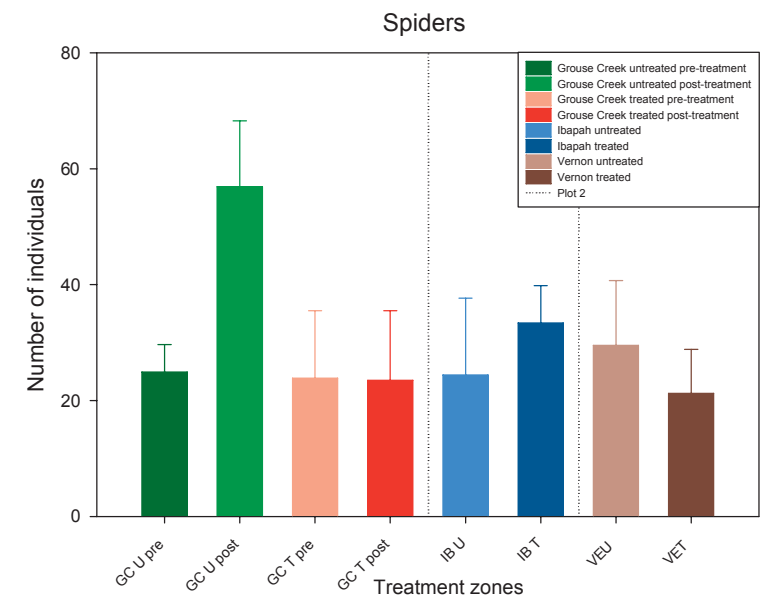

$\boldsymbol{J}$

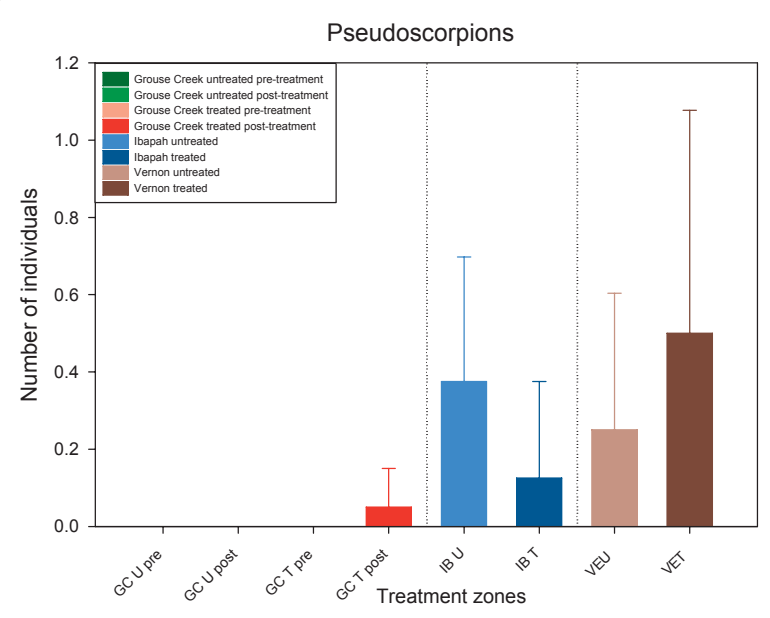

K

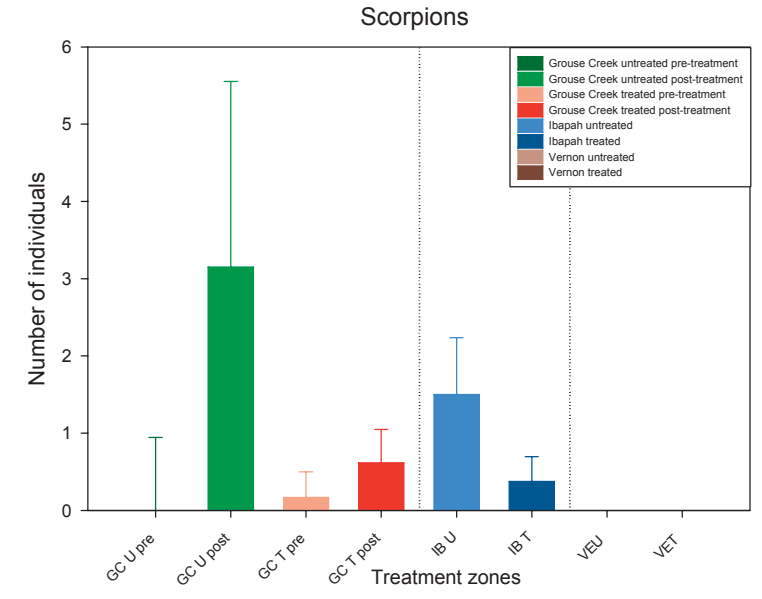

$L$

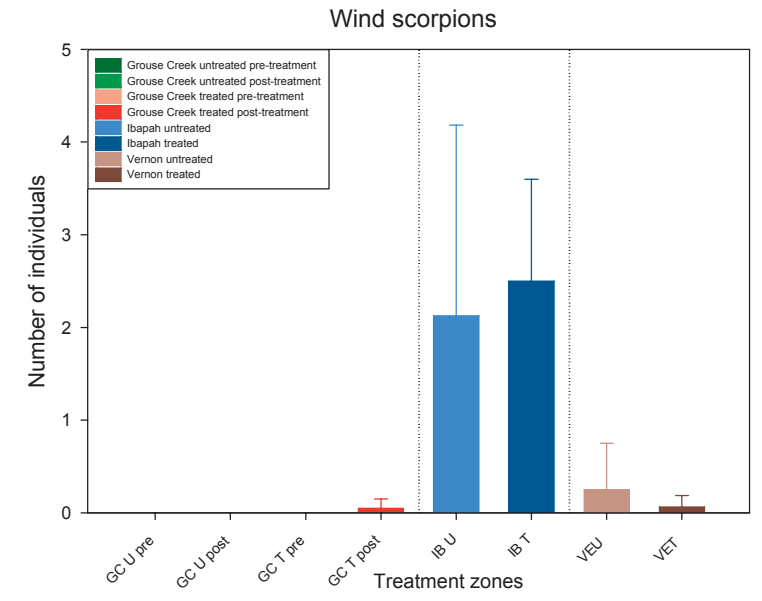

Figure 16 A-L. Average number of individuals (by taxon) in untreated (GC U pre- and post-treated, IB U, VE U) and treated (GC T preand post-treated, IB T, VE T) zones at the three study areas-Continued. 
the post-treatment collections at unsprayed sites. Coleoptera $\left(t_{d . f .6}=-2.053 ; P=0.086\right)$, Hemiptera $\left(T_{d . f .6}=12 ; P=0.114\right)$, and Scorpiones $\left(t_{d . f .}=-1.926 ; P=0.102\right)$ also showed large increases in average abundance from pre- to post-treatment collections but the differences were not statistically significant.

\section{Pre- versus Post-Treatment Changes in Treated Zone}

No significant differences in pre- and post-treatment numbers occurred within the sprayed zone, although Hemiptera $\left(t_{\text {d.f. } 6}=-1.992 ; P=0.093\right)$, non-ant Hymenoptera $\left(t_{\text {d.f. } 6}=-1.482 ; P=0.189\right)$, Orthoptera $\left(t_{\text {d.f. } 6}=2.419 ; P=0.052\right)$ and Scorpiones $\left(T_{d . f .6}=12.5 ; P=0.114\right)$ all had average abundance differences that were almost significant statistically. Total arthropods did not differ in the sprayed zone. Only Orthoptera showed a decrease from pre- to post-treatment numbers in the sprayed zone, indicating that diflubenzuron did accomplish the management goal of decreasing Orthoptera numbers in the sprayed zone.

\section{Pre-Treatment Changes in Untreated versus Treated Zones}

Most taxa did not differ between unsprayed and sprayed zones prior to application of diflubenzuron. There were statistically significant differences in average abundance for the Hemiptera $\left(t_{\text {d.f. }}=-2.726 ; P=0.034\right)$, non-ant Hymenoptera $\left(T_{\text {d.f. } 6}=24.5 ; P=0.035\right)$, and Orthoptera $\left(t_{\text {d.f. } 6}=-2.455 ; P=0.049\right)$. Lepidoptera numbers $\left(T_{\text {d.f. } 6}=23.5 ; P=0.114\right)$ also differed between zones but not to the point of being statistically significant. Hemiptera and Orthoptera were more abundant in the sprayed zone prior to treatment; non-ant Hymenoptera and Lepidoptera were more numerous in the unsprayed zone at the same time.

\section{Post-Treatment Changes in Untreated versus Treated Zones}

Post-treatment comparisons of unsprayed and sprayed zones showed that spiders $\left(t_{d . f .6}=4.042 ; P=0.007\right)$ and non-ant Hymenoptera $\left(T_{\text {d.f. } 6}=26 ; P=0.029\right)$ were significantly more abundant in the unsprayed zone following application of diflubenzuron. Average numbers of Lepidoptera $\left(t_{\text {d.f. } 6}=2.425\right.$; $P=0.052)$, Scorpiones $\left(t_{\text {d.f. } 6}=2.077 ; P=0.083\right)$, and total arthropods $\left(T_{d . f .6}=25 ; P=0.057\right)$ also differed markedly in the sprayed and unsprayed zones but not to the point of statistical significance. In all cases, post-treatment numbers were greater in the unsprayed zone. The Lepidoptera decreased somewhat from pre-treatment levels in the unsprayed zone and increased slightly during the same timeframe in the sprayed zone, but Lepidoptera still were more abundant in the unsprayed zone. This post-treatment difference is likely the result of inherent differences in the Lepidoptera communities of the two zones.

\section{Ibapah}

Numbers of Orthoptera $\left(t_{\text {d.f. } 6}=2.569 ; P=0.042\right)$ and Scorpiones $\left(T_{\text {d.f. } 6}=25 ; P=0.029\right)$ were significantly lower in the sprayed zone at Ibapah compared to the unsprayed zone. Differences in average abundance that were almost significant were recorded for other taxa, including Coleoptera $\left(t_{\text {d.f. } 6}=1.880 ; P=0.109\right)$, Diptera $\left(t_{\text {d.f. } 6}=1.701 ; P=0.140\right)$, non-ant Hymenoptera $(t=-2.432 ; P=0.051)$, and Lepidoptera $\left(t_{\text {d.f. } 6}=0.801 ; P=0.122\right)$. For all taxa showing large differences, more individuals were caught at the unsprayed sites than at sprayed sites.

\section{Vernon}

Vernon data from this study provided the strongest indication of diflubenzuron effects on nontarget arthropods. Beetles $\left(T_{\text {d.f. } 6}=26 ; P=0.029\right)$, flies $\left(t_{\text {d.f. } 6}=3.274 ; P=0.017\right)$, Hemiptera $\left(t_{\text {d.f. } 6}=2.458 ; P=0.049\right)$, non-ant Hymenoptera $\left(t_{\text {d.f. } 6}=2.790\right.$; $P=0.032)$, and total arthropods $\left(t_{d . f .6}=2.650 ; P=0.038\right)$ were all significantly more abundant in the unsprayed zone than in the sprayed zone. Lepidoptera $\left(t_{d . f .6}=2.380 ; P=0.055\right)$ and Orthoptera $\left(t_{d . f .6}=1.485 ; P=0.188\right)$ also had greater average numbers in the unsprayed zone than in the sprayed sone, although the differences were not quite significant.

\section{Terrestrial Community Structure}

Multivariate analysis (NMS) showed no useful ordination solution using either raw data (average numbers caught per day), or log-transformed data. There was no apparent structure in the data; most of the sites were in a single, large cluster with a few (primarily those with very high or very low numbers of Hemiptera) separated individually from the main grouping. Final stress values for the dataset did not differ from analysis with randomized data, indicating that community structure was weak (McCune and Grace, 2002). This result may have been due to the influence of particular taxa (for example, Hemiptera) at individual sites. Examination of the data indicated that GC U05 post-treatment and IB U08 were outliers in the raw-numbers dataset, and VE U08 and VE T01 were outliers after the data were transformed, based on the PC-ORD outlier test (McCune and Grace, 2002). GC U05 post-treatment and IB U08 were heavily dominated by Hemiptera, with more than 90 percent of all specimens in this order (figs. $12 B$ and $14 A$ ). It is not clear why VE U08 was identified as an outlier because no group seemed particularly over- or underrepresented. VE T01 had fewer Hemiptera than any other site, with the exception of the GC U11 pre-treatment collection, and was dominated by ants but not by a higher proportion than at other sites. Removing these outliers did not improve ordination results using either raw numbers or transformed data. 
Ordination with the Hemiptera removed from all sites provided a very strong two-axis solution that explained 95.5 percent of the variation in the dataset. This solution left IB T22 isolated from the other sprayed sites at Ibapah, despite what appeared to be very similar communities among the sites. The one significant difference between IB T22 and the other sprayed sites was that no Microcoryphia (silverfish) were found at any Ibapah site except IB T22, where 219 silverfish were collected (no other site in the study had more than 19 silverfish). Ordination (NMS) was then performed, excluding both Hemiptera and Microcoryphia data for all sites (fig. 17).

Ordination with the reduced dataset resulted in a good two-dimensional solution (final stress $=10.0747$ ) that explained 92.6 percent of the variation in the dataset. Very little change occurred in the position of the sites, except that IB T22 was brought into close proximity with the other three sprayed sites at Ibapah, and additional separation was achieved between treated and untreated sites at Vernon. The first axis was defined primarily by ant abundance, with some influence from non-ant Hymenoptera numbers. Flies and beetles provided most of the structure on the second axis.

Ibapah and Vernon sites were largely separated from Grouse Creek sites based on abundance of beetles and flies (greater numbers at Grouse Creek) and ants (fewer numbers at Grouse Creek); the former two taxa influenced the position along the second axis, while ants structured sites along the first axis. Abundance of solifugids at Ibapah, beetles and pseudoscorpions at Vernon, and beetle numbers at Grouse Creek also influenced the location of sites in the ordination.

\section{Grouse Creek}

Grouse Creek community data indicated a consistent temporal shift for both sprayed and unsprayed sites from pre-treatment (late May and early June) communities to post-treatment (late June) communities, except for GC U05, GC T03, and GC T05 (fig. 17). The basic pattern of data change consisted in a shift to the left and a weak-to-moderate shift down in ordination space. Community structure changed with increases in total arthropod abundance, Coleoptera (beetles), Formicidae (ants), and non-ant Hymenoptera (bees and wasps) from preto post-treatment collections. Flies (Diptera) increased at all unsprayed sites and at GC T04 and GC T06 but declined at GC T03 and GC T05. Beetle numbers increased from pre- to post-treatment collections at all sites except GC T05. Sites GC U01 and GC U05 were separated at the bottom of the ordina-

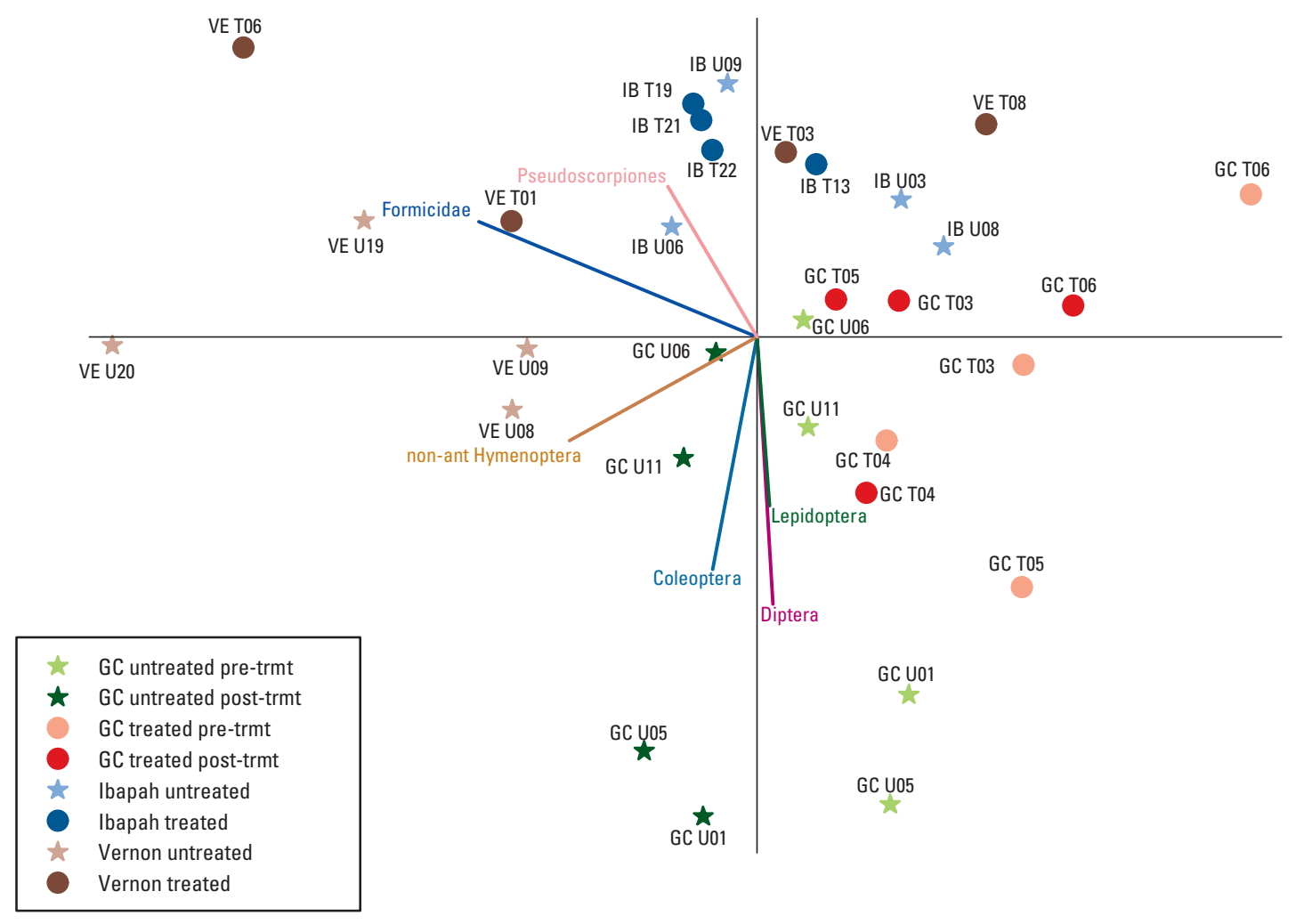

Figure 17. Nonmetric multidimensional scaling ordination for all sites, excluding Hemiptera and Microcoryphia. Vectors represent taxa significantly influencing the spread of sites along the two axes. 
tion space and changed primarily along the first axis from preto post-treatment collections; these two sites had more beetles than any other site, especially in pre-treatment collections.

The magnitude of increase in abundance differed between sprayed and unsprayed sites, with many more arthropods being caught at unsprayed sites after treatment than at sprayed sites (appendix A1a and A1b). The variation among sites, even within a treatment zone or collection period, kept many of these differences from being statistically significant, but the trend is evident when all 16 sampling events are examined (appendix A1a and A1b). Additional work is needed to determine whether application of diflubenzuron reduces arthropod abundance, or whether observed differences are related to inherent site differences.

\section{Ibapah}

Community structure of Ibapah sites was based primarily upon ant abundance. Without Hemiptera (true bugs and leafhoppers) and Microcoryphia (silverfish), the four sprayed sites at Ibapah formed a tight cluster along the second axis, along with IB U09; these five Ibapah sites had similar numbers of ants. The IB U09 ant community resembled communities at the sprayed sites as well, though genus-level data were not included in the dataset used in this ordination. Similarities between IB U09 and the sprayed sites at Ibapah underscore the influence of inherent site properties in structuring arthropod communities. Two of the unsprayed sites (IB U03 and IB U08) were shifted to the right relative to the sprayed sites; these two sites had fewer ants than any other Ibapah site. IB U06, the fourth unsprayed site, had ant numbers similar to the sprayed sites but had more flies, separating it from the sprayed cluster along the second axis. There was little variation along the second axis among the eight Ibapah sites, but what differences did occur were due essentially to differences in abundance of Diptera at each site.

\section{Vernon}

As was the case at Ibapah, ant abundance structured the Vernon sites, with more ants at the unsprayed sites than at most of the sprayed sites. Proximity in the multivariate plot to other sites from any study area appeared to be dictated by similar ant numbers. The sprayed sites were scattered across ordination space on the first axis but within a narrow belt on the second axis; large variation in ant abundance at sprayed sites (418 to 2,306 total ants) caused this spread on the first axis. The range of ants collected at unsprayed sites overlapped sprayed sites ( 870 to 2,826 ants), but the trend was for more ants at unsprayed sites, which accounts for their shift to the left along the first axis (fig. 17). Unsprayed sites also had more beetles and flies than did sprayed sites, and a greater variation in these taxa. The increased numbers of beetles and flies and their greater variation in taxa is reflected in the spread in unsprayed site locations along the second axis and in the small variation in second axis ordination scores for the sprayed sites, which showed less variation in numbers of flies or beetles (appendix A1d).

Range in ordination space was greater for Vernon sites than for Ibapah or Grouse Creek sites, due at least in part to the greater spatial and elevational spread among the sites of the Vernon study area. For example, VE T06 was isolated from all other sites on the ground, being farther west, and was identified as an outlier by using the PC-ORD outlier analysis routine. VE T06 had more beetles and ants, but fewer flies, than the other treated sites. The other outlier identified (of all 32 communities included in the analysis) was VE U20, which was higher in elevation and slightly farther south than the other unsprayed Vernon sites (fig. 4, table 1). More ants were collected at VE U20 than at any other site in the study (2,826 ants); flies also were more abundant, and spiders were less common than at other unsprayed sites. Although data on Hemiptera were not included in the ordination analysis, these two sites also differed from the other Vernon sites in numbers of Hemiptera; VE T06 had more Hemiptera than any other sprayed site, and VE U20 had only about half as many Hemiptera as the other unsprayed sites.

\section{Formicidae}

Eighteen genera of ants were collected across the three study areas (table 2). Untreated sites at Grouse Creek had 15 genera; 16 genera were found at sites in the treated zone. Ibapah untreated sites had 11 genera; 14 genera were found at sites in the treated zone. This trend was reversed at Vernon, where 13 genera were found at sites in the untreated zone, and 10 genera were found at sites in the treated zone. Vernon ant communities were slightly less genera rich, but ants were more abundant at Vernon (10,711 ants total) than at the other two study areas. At the eight Ibapah sites, 4,968 ants were collected. Grouse Creek unsprayed sites accounted for 3,622 ants from both collection periods, while 2,887 ants were collected from sprayed sites during the two sampling periods.

\section{Grouse Creek}

Ant communities differed in composition among sampling events and sites in the treated and untreated zones at Grouse Creek (fig. 18). Differences appeared to be due to ant phenology and intrinsic site differences, not the application of diflubenzuron. Formica were particularly abundant at Grouse Creek, except at GC T03 and GC T05. These two sites were the rockiest sites; GC T03 was on a hillside, GC T05 was at the nose of a small ridge. There were more Pogonomyrmex at untreated sites and more Pheidole at treated sites, but these differences, which existed prior to treatment, were not related to the insecticide. Seed-harvester numbers increased at nearly every Grouse Creek site from pre- to post-treatment collections. Forelius was found only at GC U11 and GC T03; Forelius increased at GC U11 from late May to late June but declined over the same period at GC T03. 
Table 2. Ant genera found in each west desert treatment zone and during each sampling period, Utah.

[Functional group designations assigned from Nash and others (2001, 2004). G, generalist; P, predator; HT, Homoptera tender; SH, seed harvester; LF, liquid feeder; SM, slave maker.]

\begin{tabular}{|c|c|c|c|c|c|c|c|c|c|}
\hline Ant genera & $\begin{array}{l}\text { Functional } \\
\text { group }\end{array}$ & $\begin{array}{c}\text { Grouse } \\
\text { Creek } \\
\text { untreated } \\
\text { pre-treat- } \\
\text { ment zone }\end{array}$ & $\begin{array}{c}\text { Grouse } \\
\text { Creek } \\
\text { untreated } \\
\text { post-treat- } \\
\text { ment zone }\end{array}$ & $\begin{array}{c}\text { Grouse } \\
\text { Creek } \\
\text { treated } \\
\text { pre-treat- } \\
\text { ment zone }\end{array}$ & $\begin{array}{c}\text { Grouse } \\
\text { Creek } \\
\text { treated } \\
\text { post-treat- } \\
\text { ment zone }\end{array}$ & $\begin{array}{c}\text { lbapah } \\
\text { untreated } \\
\text { zone }\end{array}$ & $\begin{array}{l}\text { Ibapah } \\
\text { treated } \\
\text { zone }\end{array}$ & $\begin{array}{c}\text { Vernon } \\
\text { untreated } \\
\text { zone }\end{array}$ & $\begin{array}{c}\text { Vernon } \\
\text { treated } \\
\text { zone }\end{array}$ \\
\hline Aphaenogaster & G & $\mathrm{X}$ & $\mathrm{X}$ & $\mathrm{X}$ & $\mathrm{X}$ & & $\mathrm{X}$ & $\mathrm{X}$ & $\mathrm{X}$ \\
\hline Camponotus & G & $\mathrm{X}$ & $\mathrm{X}$ & $\mathrm{X}$ & $\mathrm{X}$ & $\mathrm{X}$ & $\mathrm{X}$ & $\mathrm{X}$ & $\mathrm{X}$ \\
\hline Cardiocondyla & $\mathrm{P}$ & & & $\mathrm{X}$ & & & $\mathrm{X}$ & & \\
\hline Crematogaster & G & & & $\mathrm{X}$ & $\mathrm{X}$ & & $\mathrm{X}$ & & \\
\hline Forelius & HT & $\mathrm{X}$ & $\mathrm{X}$ & $\mathrm{X}$ & $\mathrm{X}$ & $\mathrm{X}$ & $X$ & $\mathrm{X}$ & $X$ \\
\hline Formica & HT & $\mathrm{X}$ & $\mathrm{X}$ & $\mathrm{X}$ & $\mathrm{X}$ & $\mathrm{X}$ & $\mathrm{X}$ & $\mathrm{X}$ & $\mathrm{X}$ \\
\hline Lasius & HT & $X$ & $\mathrm{X}$ & $X$ & $\mathrm{X}$ & $\mathrm{X}$ & & $\mathrm{X}$ & \\
\hline Leptothorax & G & $\mathrm{X}$ & $\mathrm{X}$ & $X$ & $\mathrm{X}$ & $\mathrm{X}$ & $\mathrm{X}$ & $\mathrm{X}$ & $\mathrm{X}$ \\
\hline Messor & SH & $\mathrm{X}$ & & & $\mathrm{X}$ & & & & \\
\hline Monomorium & $\mathrm{SH}$ & & & & & & & $\mathrm{X}$ & $\mathrm{X}$ \\
\hline Myrmecocystus & LF & $\mathrm{X}$ & $\mathrm{X}$ & $X$ & $\mathrm{X}$ & $\mathrm{X}$ & & $\mathrm{X}$ & \\
\hline Myrmica & $\mathrm{P}$ & $\mathrm{X}$ & $\mathrm{X}$ & $\mathrm{X}$ & $\mathrm{X}$ & $\mathrm{X}$ & $X$ & $\mathrm{X}$ & $\mathrm{X}$ \\
\hline Pheidole & SH & $\mathrm{X}$ & $\mathrm{X}$ & $\mathrm{X}$ & $\mathrm{X}$ & $\mathrm{X}$ & $X$ & $\mathrm{X}$ & $\mathrm{X}$ \\
\hline Pogonomyrmex & SH & $\mathrm{X}$ & $X$ & $\mathrm{X}$ & $\mathrm{X}$ & $\mathrm{X}$ & $X$ & $\mathrm{X}$ & $X$ \\
\hline Polyergus & SM & & $\mathrm{X}$ & $\mathrm{X}$ & $\mathrm{X}$ & & $\mathrm{X}$ & & \\
\hline Prionopelta & $\mathrm{P}$ & & $\mathrm{X}$ & & & & & & \\
\hline Solenopsis & G & $\mathrm{X}$ & $\mathrm{X}$ & $\mathrm{X}$ & $\mathrm{X}$ & $X$ & X & $\mathrm{X}$ & $\mathrm{X}$ \\
\hline Tapinoma & G & $X$ & $X$ & $\mathrm{X}$ & $X$ & $X$ & $X$ & $X$ & \\
\hline
\end{tabular}

\section{Ibapah}

Ants at Ibapah differed from site to site, but there were some patterns correlated with whether or not the sites had been treated with diflubenzuron in 2004. Untreated sites showed a large proportion of the community composed of ants in the genera Formica, Leptothorax, and Tapinoma, while Forelius, Pheidole, and Pogonomyrmex dominated collections from treated sites (fig. 19). IB U09 was unusual for an untreated site because of the high numbers of Forelius found there. It is not clear what features of IB U09 were more similar to the treated sites than to the other untreated sites, except that IB U09 was closer to the treatment zone than the others. Numbers of Tapinoma and Leptothorax at IB U09 were comparable to the other untreated sites but Formica was rare.

\section{Vernon}

Community composition of ants at Vernon also was different at each site, but structure again appeared to be correlated with treatment history (fig. 20). Tapinoma was found at three of the four untreated sites but not at any treated sites.
Forelius was present at all four treated sites; one ant found at VE U20 was the only Forelius found at any untreated site. Pogonomyrmex was rare at Vernon, occurring at only two sites (one treated and one untreated). Pheidole, an important seed harvester, also was relatively uncommon at Vernon sites. Monomorium, another seed-harvesting ant, was found only at Vernon, occurring at all eight sites. On average, Formica was more abundant at untreated sites, although numbers varied considerably; it occurred at only two treated sites and ranged from common to uncommon at those sites.

\section{Comparisons Among Study Sites}

Most Grouse Creek ant communities were dominated by Formica or Pogonomyrmex (fig. 18). Ibapah ant communities were characterized by Tapinoma and Formica at untreated sites and Forelius at treated sites (fig. 19). The ant communities at Vernon were distinguished by the presence of Monomorium at all eight sites (fig. 20). There were some similarities between Vernon and Ibapah communities that were consistent with treated and untreated zones at both study areas. Formica and Tapinoma were common to abundant at untreated sites at 
Vernon and Ibapah, and ants of the genus Forelius were very common at most of the treated sites at both study areas.

\section{Ant Community Structure}

Ordination (NMS) resulted in a three-dimensional solution providing the best fit and lowest stress (final stress $=10.762$ ) and explaining approximately 87 percent of the variation within the dataset. For the sake of graphic simplicity, we present the two-dimensional depiction of axes two and three, which explain about 67 percent of the variation (fig. 21). Axis one was defined primarily by the inverse relationship between Pogonomyrmex and Monomorium, with some influence from Solenopsis. Monomorium was found only at the eight sites of the Vernon study area, while Pogonomyrmex was common at Grouse Creek and Ibapah but was present at Vernon in small numbers at only two sites. The second axis was structured by the abundance of Formica, with Tapinoma and Leptothorax influencing structure as well. The presence of Crematogaster, which occurred at only three sites (GC T03 before and after treatment, IB T19, and IB T22), also influenced scores for NMS axis two and helped separate the latter sites to the left side of the ordination space. Abundance of Forelius defined the third axis, with the Vernon and Ibapah
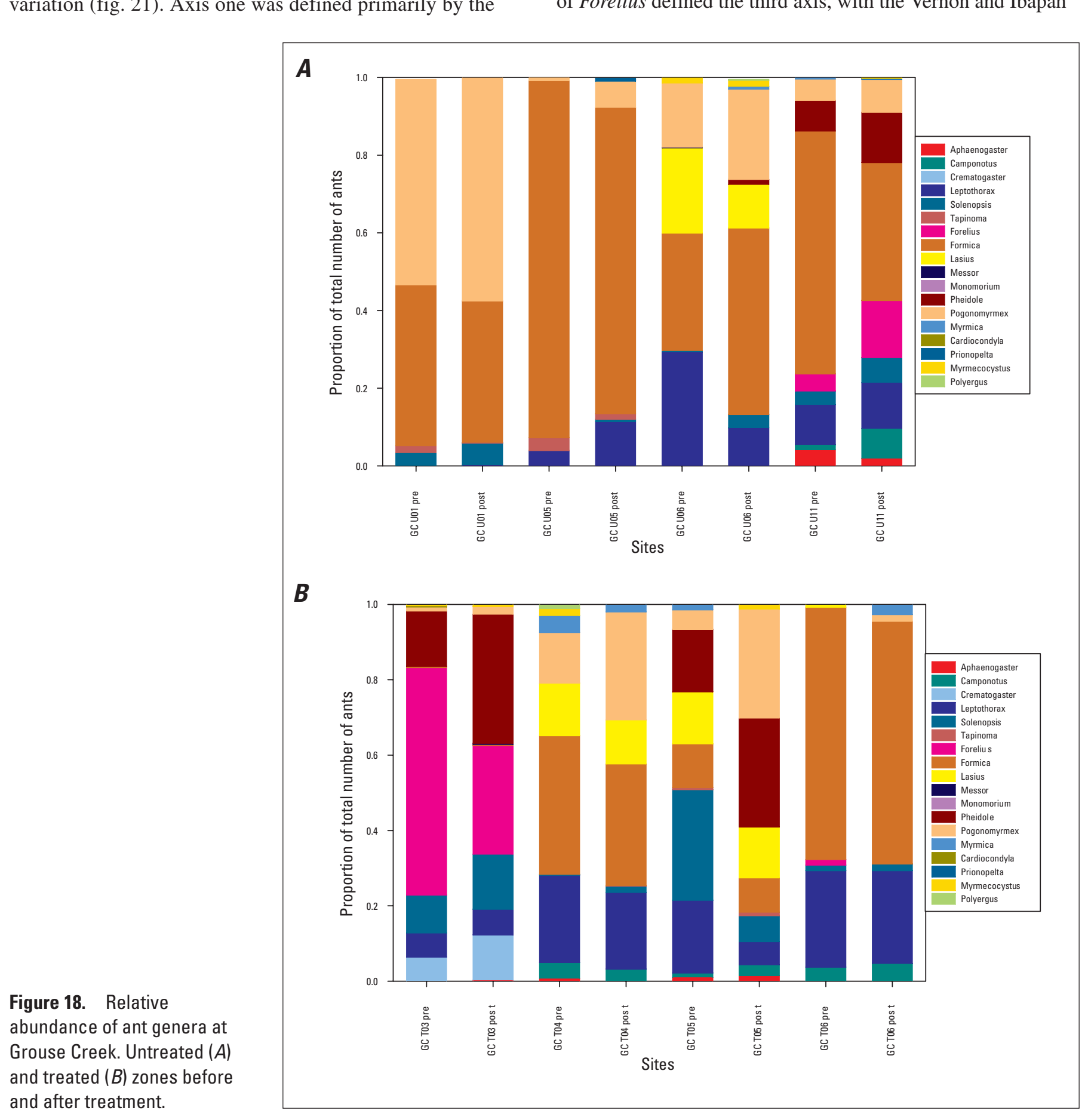

Figure 18. Relative abundance of ant genera at Grouse Creek. Untreated $(A)$ and treated $(B)$ zones before and after treatment. 

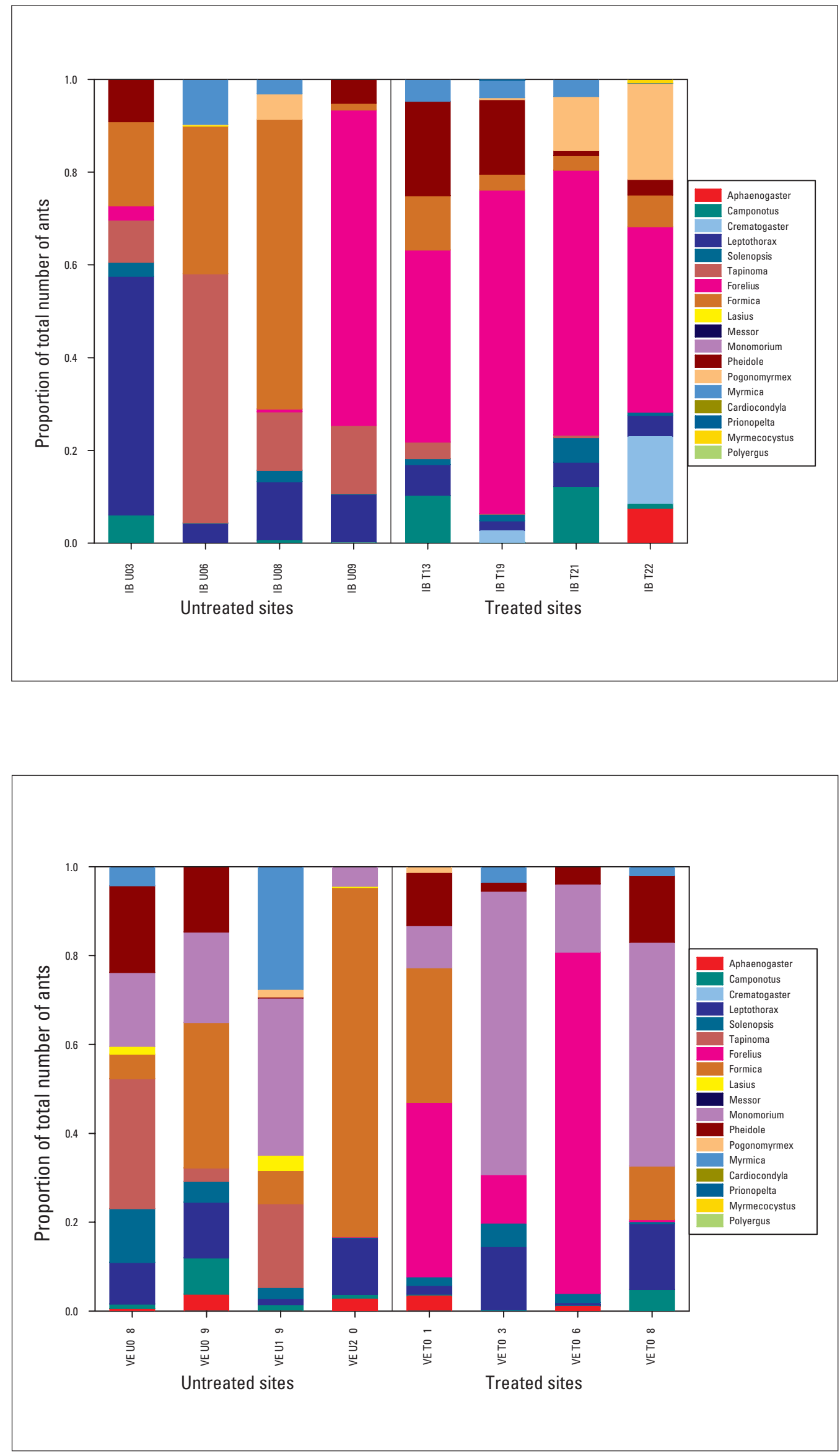

Figure 19. Relative abundance of ant genera at lbapah untreated and treated zones.
Figure 20. Relative abundance of ant genera at Vernon untreated and treated zones. 
treated sites stretched along the third axis primarily according to abundance of Forelius. This genus was largely absent from Grouse Creek, being found at only three sites (and rare at two of the three sites) (appendix A2). Forelius was abundant only at GC T03, and this Grouse Creek site was the only site with positive axis-three scores. Most Grouse Creek unsprayed-zone ant communities were defined by relatively high numbers of Formica, Pogonomyrmex, and Leptothorax and the absence of Tapinoma, Monomorium, and Forelius. Temporal shifts for the Grouse Creek sites did not show any pattern relative to diflubenzuron application, or any other factor that was examined.

Ibapah ant communities separated into sprayed and unsprayed communities primarily on the abundance of Forelius at the sprayed sites. IB U09 was near the sprayed-zone sites because it also had a high abundance of Forelius (appendix A2). The unsprayed sites at Ibapah were scattered throughout the ordination space; each of the four sites had a different ant genus as the most abundant taxon.

The sprayed Vernon sites showed almost no variation along the second axis; their locations were almost entirely based on abundance of Forelius. The unsprayed sites had essentially no Forelius (one individual at VE U20) and were separated from the sprayed sites on this basis. Abundance of Formica, Tapinoma, and Leptothorax influenced the location of the unsprayed sites at Vernon. All the unsprayed Vernon sites were in the upper right quadrat due to the presence of Monomorium, which was found only at Vernon.

The ordination was strongly influenced by the presence of Forelius; the location of IB U9 and GC T03 in the same region of ordination space as Ibapah and Vernon sprayed sites strengthens this conclusion. Other than dominance by Forelius, there was considerable variation among sites; however, some other genera appear to exhibit trends.

Total numbers of ants differed somewhat between sprayed and unsprayed sites at all three study areas, but the average number of ants in each treatment zone at a study area were not significantly different. However, the abundance of the various genera that made up the "ant" category in the statistical analyses was sometimes quite different among sites and between sprayed and unsprayed zones (table 3 ).

\section{Hemiptera}

Immature Hemiptera are difficult to identify, even to family, especially by nonexperts. Because most individuals were nymphs, we had large numbers of unidentified Hemiptera in some samples. To address this problem, we estimated total numbers of Hemiptera in each family. The total number of Hemiptera identified in each family and the total of all Hemiptera excluding unknowns were calculated, and the total for each family was divided by the grand total to generate the proportion of identified Hemiptera in each family. The proportion of Hemiptera in each family was multiplied by the total number of unknown Hemiptera caught to estimate the number of nymphs in each family. This value was added to the number of adults to estimate the total number in each family. We recognize that this approach has inherent problems, especially based on the phenology of the different taxa, and that some
Figure 21. Nonmetric multidimensional scaling joint plot of ant genera as number of ants per day at Grouse Creek, Ibapah, and Vernon. Includes data from before and after treatment at Grouse Creek and the treated and untreated sites of all three areas. Lines indicate genera strongly influencing separation of sites along one or both axes.

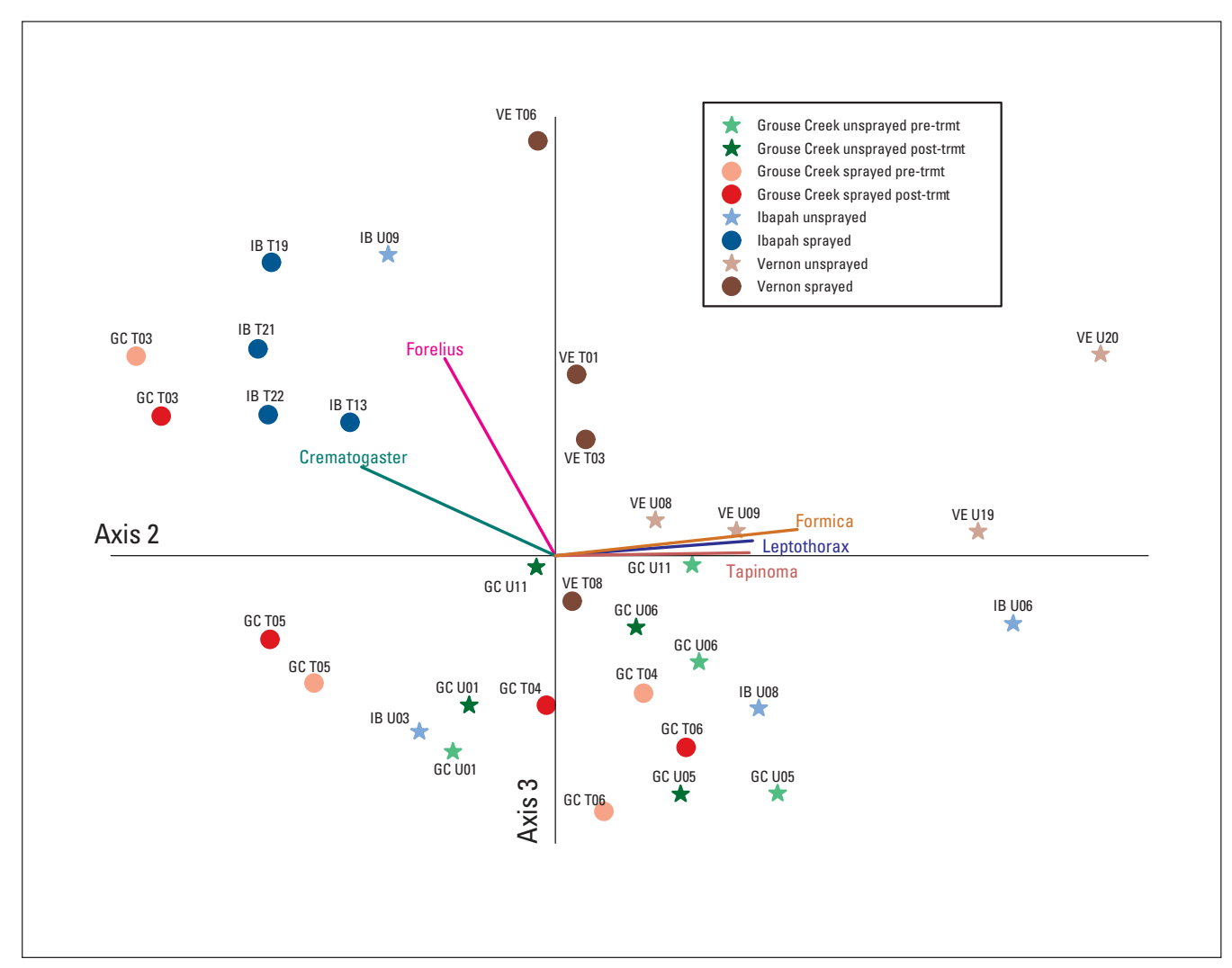


Table 3. Total number of ants of the nine most common genera collected in treated and untreated zones at Grouse Creek, Ibapah, and Vernon study sites after treatment with diflubenzuron.

[*IB U9 accounted for 541 of the Forelius in untreated traps].

\begin{tabular}{lccccrr}
\hline \multicolumn{1}{c}{ Genus } & \multicolumn{2}{c}{ Grouse Creek after treatment } & \multicolumn{2}{c}{ lbapah after treatment } & \multicolumn{2}{c}{ Vernon after treatment } \\
& Untreated & Treated & Untreated & Treated & Untreated & Treated \\
\hline Forelius & 127 & 442 & 544 & 1,396 & 1 & 2,239 \\
Formica & 963 & 101 & 536 & 158 & 2,700 & 396 \\
Leptothorax & 197 & 251 & 273 & 101 & 581 & 181 \\
Monomorium & 0 & 0 & 0 & 0 & 1,055 & 1,043 \\
Myrmica & 7 & 24 & 92 & 103 & 497 & 29 \\
Pheidole & 122 & 238 & 57 & 257 & 314 & 297 \\
Pogonomyrmex & 535 & 300 & 19 & 256 & 29 & 14 \\
Solenopsis & 109 & 95 & 44 & 42 & 198 & 102 \\
Tapinoma & 3 & 5 & 647 & 24 & 597 & 0 \\
Totals & 2,063 & 1,456 & 2,212 & 2,337 & 5,972 & 4,301 \\
\hline
\end{tabular}

families might have been represented only by adults, or only by nymphs, at the time of collections. Because the samples at each study area were collected at the same time, we believe any inaccuracies will be consistent across that sampling period.

\section{Grouse Creek}

\section{Pre- versus Post-Treatment Changes in Untreated Zone}

Community composition of Hemiptera varied from site to site and over time at Grouse Creek (figs. 22A and B). Cicadellidae were the most abundant Hemiptera at most sites, but GC U01 and GC U05 sites were dominated by the Alydidae in late June (post-treatment period), representing a dramatic increase in this family from the early June sampling event. Most other families were relatively rare at Grouse Creek sites; Miridae were uncommon to abundant at some untreated sites and increased from pre- to post-treatment collections. The only other family that occurred with any frequency was the Aphididae. The GC U11 Hemipteran community appeared to differ from communities at the other untreated sites.

\section{Pre- versus Post-Treatment Changes in the Treated Zone}

The treated sites at Grouse Creek also were dominated by the Cicadellidae, even more strongly than in the untreated zone, during both sampling periods (fig. 22B). The Alydidae were absent from all treated sites prior to treatment; they were captured in post-treatment samples but in much lower numbers than at post-treatment unsprayed sites. Aphids were again present in all collections and increased across the two collection periods. The Miridae were less frequent in the treated zone and showed only a slight increase from pre- to post- treatment collections, while the increase in Miridae abundance in the untreated zone was large.

The Lygaeidae were absent from both untreated and treated zones prior to treatment at Grouse Creek. No Lygaeids were detected in the treated zone 3 weeks after treatment, but low numbers (averaging 1.9 individuals per day) were detected at each untreated site in the post-treatment collection period. Although there was no difference in numbers of Lygaeidae in the treated zone before and after treatment (no individuals were detected), the comparison between post-treatment untreated and treated zones was significantly different $\left(T_{d . f .6}=26 ; P=0.029\right)$. The phenology of the Lygaeidae may account for the lack of any individuals being detected in pre-treatment samples from either treatment zone; they may emerge later in the season and were not active during the early sampling period.

\section{Ibapah}

\section{Zones Treated in 2004 versus Untreated Zones}

Cicadellidae dominated six of eight Ibapah sites, with the Alydidae most numerous at IB U08 and IB T13 (fig. 23). The Alydidae were present at all eight Ibapah sites, but each treatment zone had one site where the Alydidae dominated the collection of Hemiptera. IB U08 and IB T13 appeared to have finer soils; greasewood, saltbush, and other shrubby Chenopodeaceae made up a significant portion of the shrub component of the vegetation at these two sites. Sagebrush was relatively scarce at IB U08 but common at IB T13. The Lygaeidae had significantly more individuals in untreated sites than treated sites $\left(T_{d . f .6}=26 ; P=0.029\right)$. 
Vernon

\section{Sites Treated in 2004 versus Untreated Sites}

Vernon hemipteran communities differed among sites and were more diverse than Ibapah or Grouse Creek communities (fig. 24), with Cicadellidae dominating some sites; other families, such as the Lygaeidae, Miridae, Nabidae, and Psyllidae, were common. As at Ibapah and Grouse Creek, no pattern in the community structure appeared to be associated with the treatment history at Vernon. The Lygaeidae, which showed indications of sensitivity to diflubenzuron at Grouse Creek and Ibapah, were highly variable at Vernon, but total numbers hinted at sensitivity to diflubenzuron (63 caught in the untreated zone, 32 caught in the treated zone).

\section{Community Structure of Hemiptera}

Ordination of numbers per day for hemipteran families did not provide a good solution because the Cicadellidae (at most sites) and the Alydidae (at a few sites) overwhelmed the variation among other families. Data were adjusted by adding 0.01 to each value to eliminate zeros and then log transformed in PC-ORD (McCune and Mefford, 2005) to compress high values (as suggested by McCune and Grace, 2002) of the Cicadellidae and Alydidae; the Euclidean distance measure

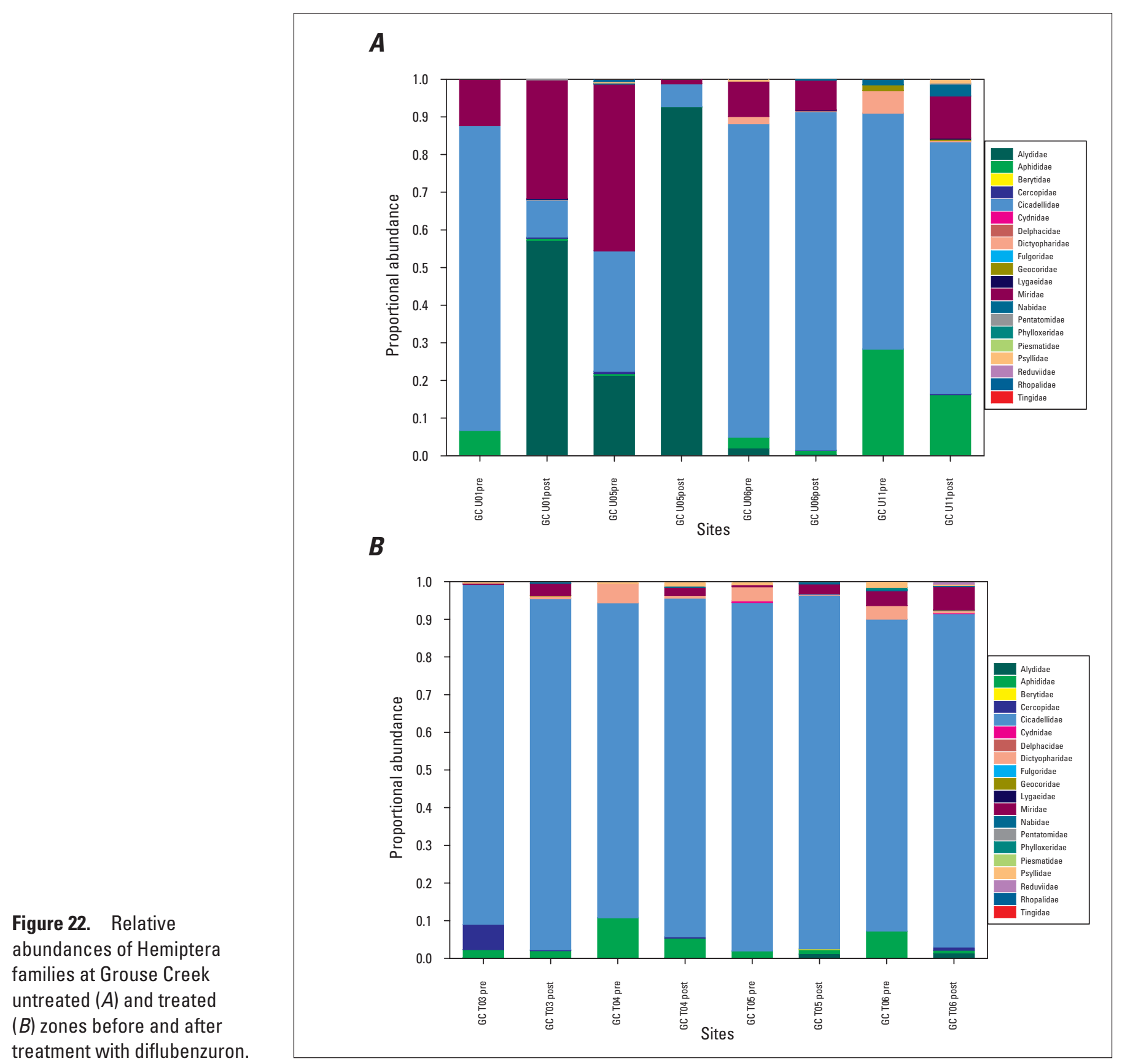


was used. Ordination of transformed data resulted in a threeaxis solution that explained 89.2 percent of the dataset variation; we present the first two axes, which explain 69.9 percent of the variation, for graphic simplicity (fig. 25). The Alydidade, Cercopidae, Miridae, and Nabidae influenced the first axis structure; the second axis was structured by the Aphididae and Psyllidae (negative values) and the Alydidae (positive values). Grouse Creek sites were spread across ordination space with no differences correlated with insecticide application. Seven of the eight Grouse Creek sites showed similar shifts in pre- to post-treatment community structure that were correlated with large increases in Miridae and Cicadellidae. GC U11 had only modest increases in these families (appendix A3), and it moved in ordination space differently than the other seven sites (fig. 25). The Ibapah sites were relatively isolated from most Vernon and Grouse Creek sites by the abundance of the Cicadellidae. Within the Ibapah cluster, three treated sites and two untreated sites formed a tight group. IB T13 and IB U08 were somewhat isolated on the basis of abundant Alydidae. The Vernon sites were scattered throughout ordination space with no apparent pattern (fig. 25).
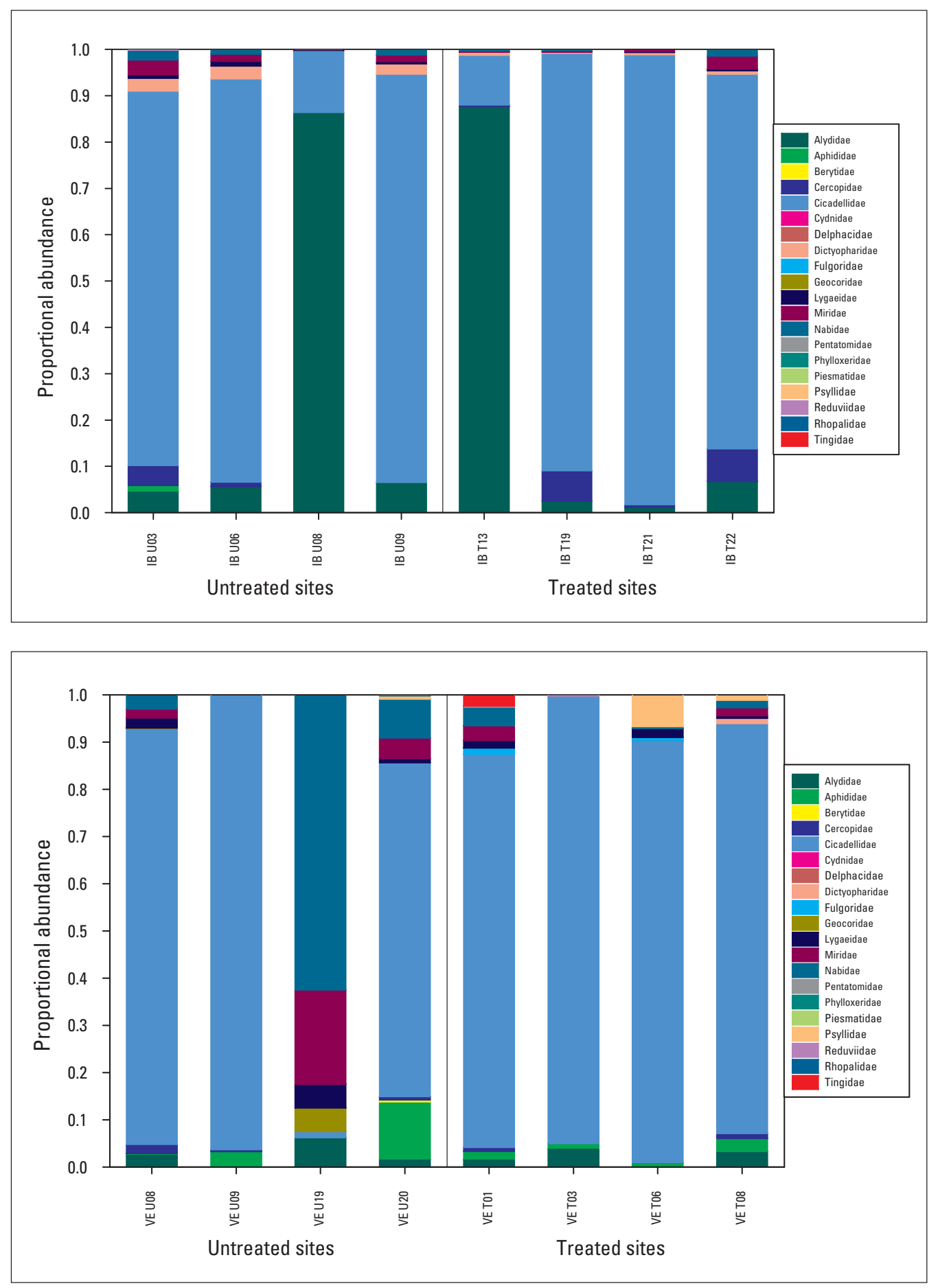

Figure 23. Relative abundances of Hemiptera families at Ibapah treated and untreated sites.
Figure 24. Relative abundances of Hemiptera families at Vernon untreated and treated sites. 
The abundant Hemiptera in this study are phloem-feeding herbivores, such as Alydidae, Cicadellidae, and Aphididae. Many species of Cicadellidae and Aphididae are tended by ants (Buckley, 1987; Fischer and Shingleton, 2001; Offenberg, 2001) in commensal to symbiotic relationships. The Geocoridae and Nabidae consist mostly of generalist predators, but some species may specialize on particular taxa or a particular habitat, spider webs, for example (Readio and Sweet, 1982; Schuh and Slater, 1995). The abundance of Nabidae at some Vernon sites is surprising since predators are usually less abundant than potential prey. Total numbers of arthropods captured at Vernon sites were not particularly high (appendix A1d).

\section{Solifugae and Scorpiones}

Solifugae were rare at Grouse Creek ( 1 individual in 960 traps) and Vernon (7 individuals in 480 traps) but were common at Ibapah (74 individuals in 480 traps) and occurred at all 8 sites. Four species of Solifugae (wind scorpions) were recorded in this study. The single specimen at Grouse Creek was Eremobates ascopulatus; Vernon's seven specimens included two species, Hemerotrecha handfordana and Eremobates actenidia. Fifty-five of the wind scorpions from Ibapah were sent for identification, and three species were identified: H. handfordana (41), E. ascopulatus (10), and E. corpink (1), with three immature specimens that could not be identified. The remaining 19 specimens have been sent to Jack Brookhart (Denver Museum of Natural Sciences) for identification.

Scorpions, another large, cursorial predator, were common at both Grouse Creek and Ibapah (66 individuals found in 960 traps at Grouse Creek and 30 individuals found in 480 traps at Ibapah) but rare at Vernon (1 individual found in 480 traps). Captures at Ibapah indicated that the association between scorpions and solifugids differed in treated and untreated zones. Regression of the average number of solifugids caught per day compared to the mean number of scorpions caught per day showed a highly significant negative relationship at the untreated sites and a strong positive relationship, though not significant, among the sites treated in 2004 (fig. 26).

\section{Aquatic Sampling}

\section{Study Sites}

We collected aquatic invertebrates at 27 sites (table 4). Sites ranged in elevation from $1,597 \mathrm{~m}$ to $2,113 \mathrm{~m}$, with the most variation in elevation at Vernon, and included nine vegetation classification zones. There were eight sampling sites at Grouse Creek (fig. 27), ten at Ibapah (fig. 28), and nine at Vernon (fig. 29). Sampling sites within these three areas were located first by an indication of water on the map. We would then travel to the site and determine whether it was suitable. To the extent possible, we attempted to find similar water bodies in and outside of the treatment zone in each of the study areas. Water was rare in the study areas, and we sampled as many aquatic sites as we could locate within the three study areas.
Figure 25. Nonmetric multidimensional scaling ordination of Hemiptera families at the three study areas.

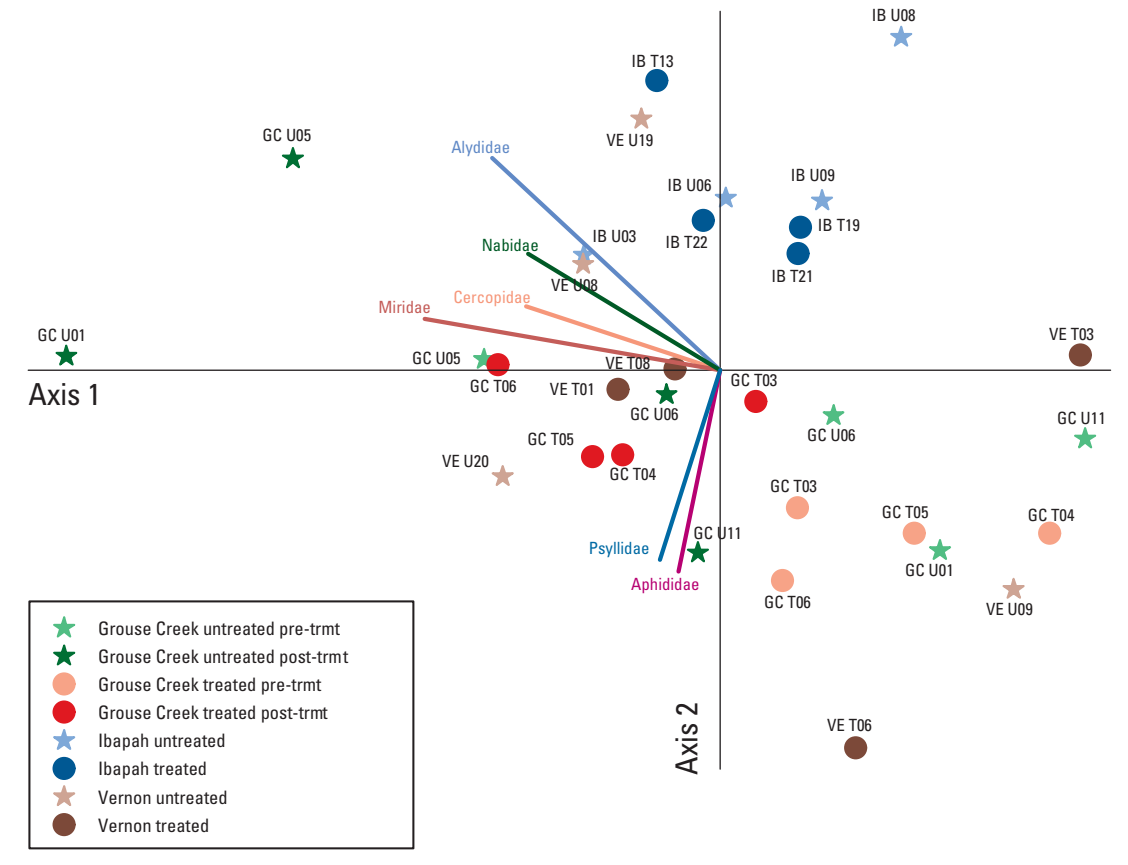



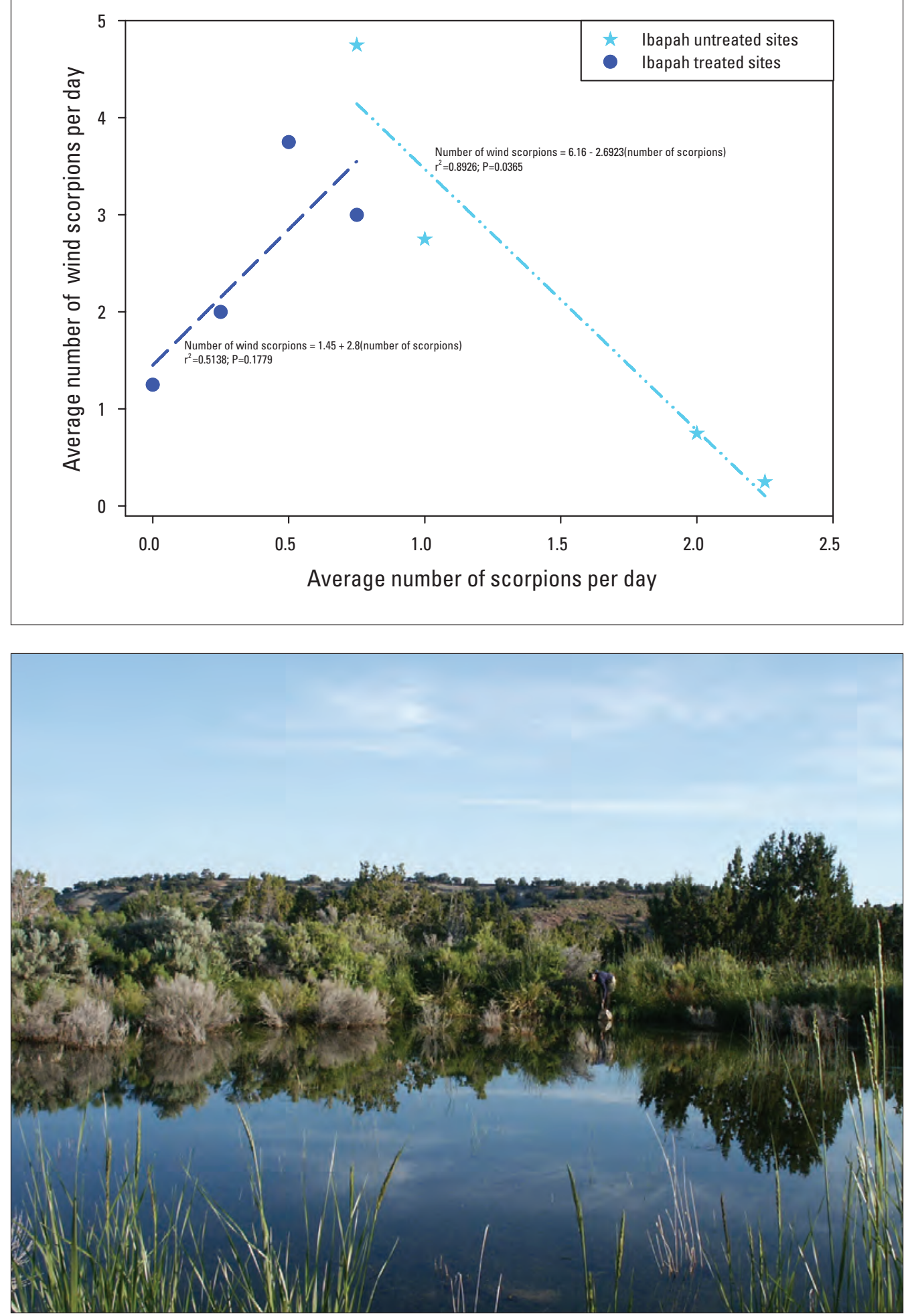

Figure 26. Number of wind scorpions per day versus number of scorpions per day at lbapah study site.

Figure 27. Aquatic site at Grouse Creek (U.S. Geological Survey photograph by Anne Brasher). 
Table 4. Aquatic site information, west desert study area, Utah.

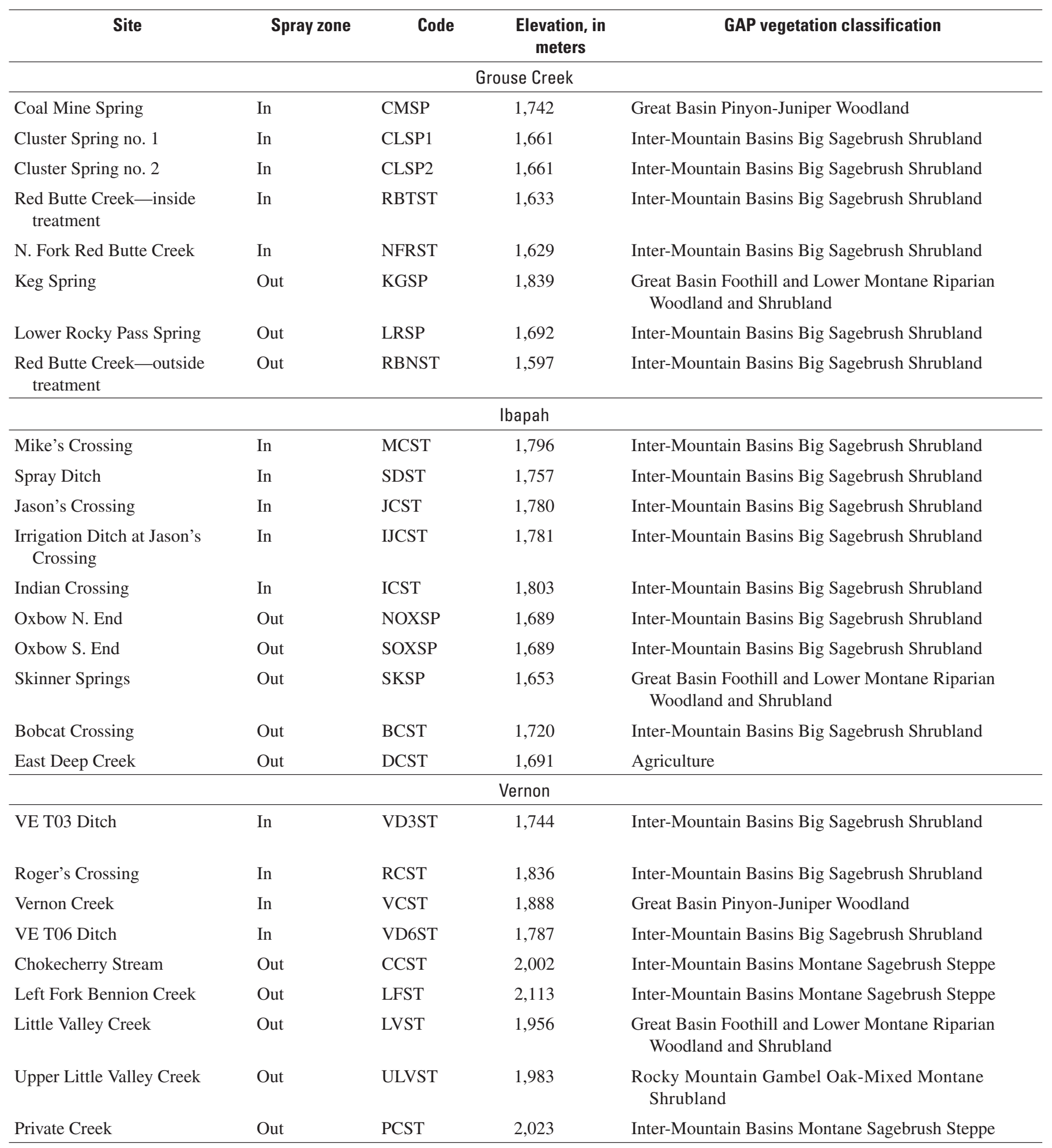



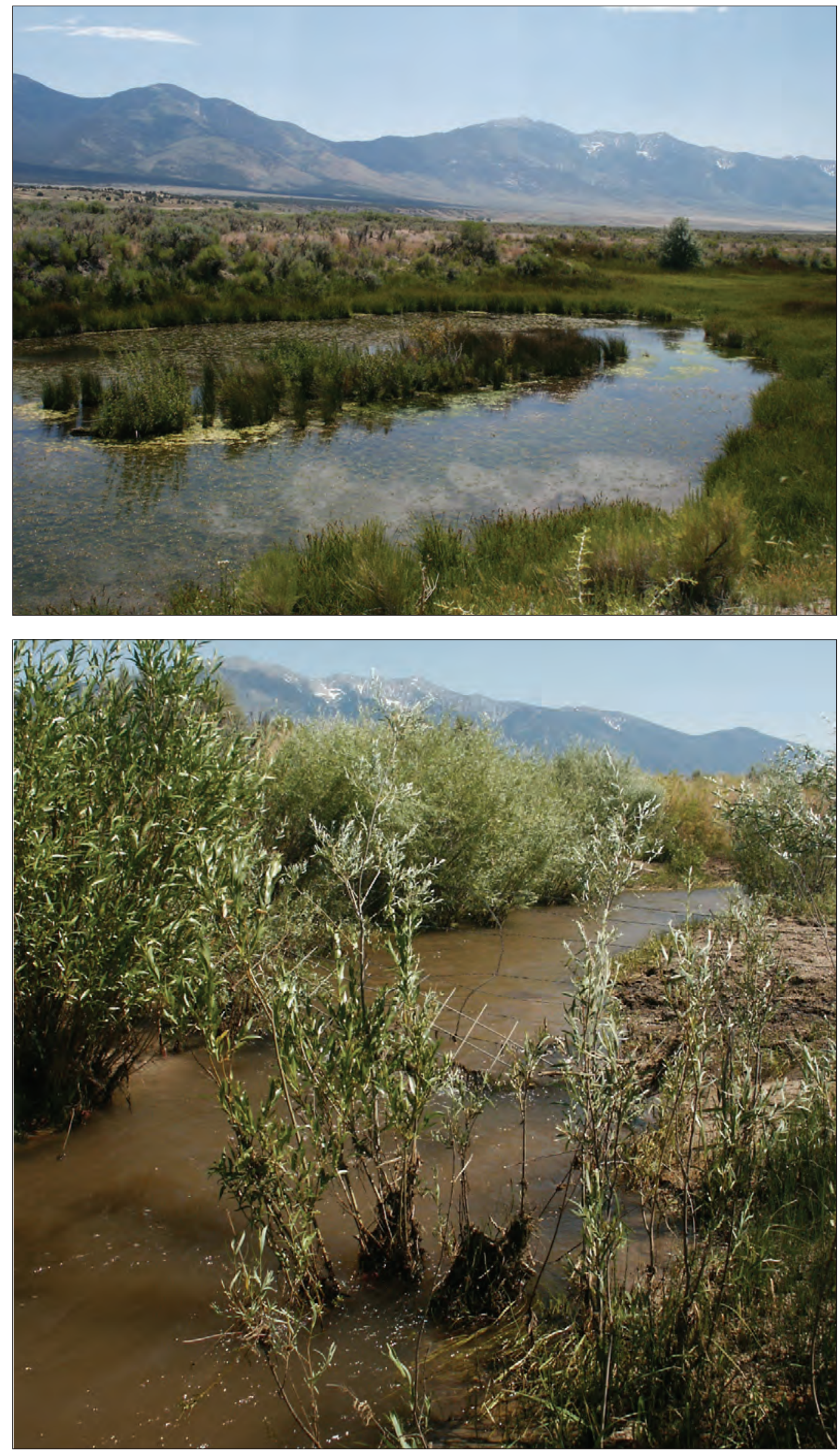

Figure 28. Aquatic site at Ibapah (U.S. Geological Survey photograph by Anne Brasher).
Figure 29. Aquatic site at Vernon (U.S. Geological Survey photograph by Becky Close). 
Table 5. Aquatic site characteristics and sampling information, west desert study areas, Utah.

[m, mud; sl, silt; sa, sand; smr, small rocks; g, gravel; c, cobble; r, rocks; b, boulder]

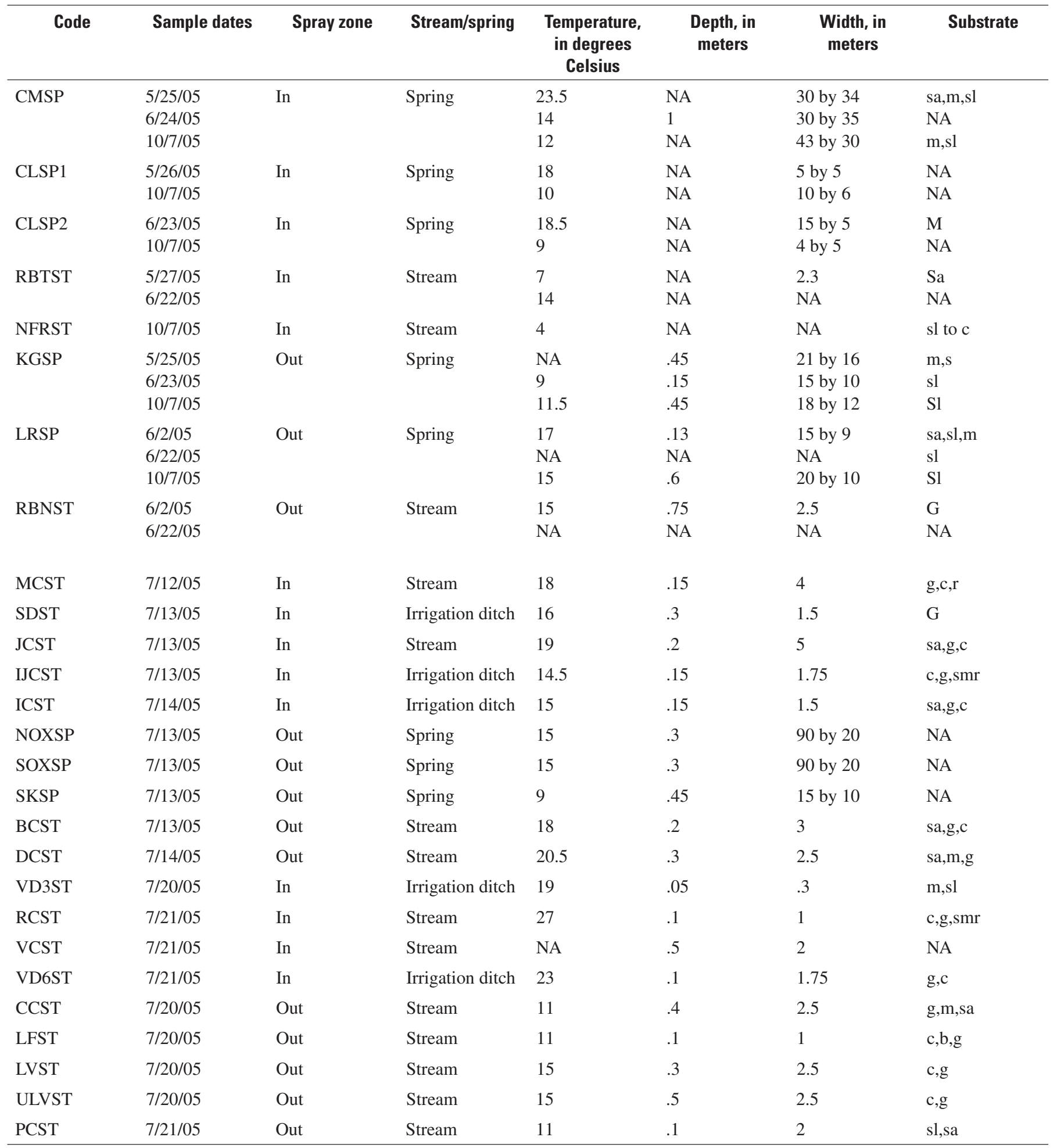


Aquatic sites consisted of both streams (including actual streams and irrigation ditches) and springs (table 5). There were five sites in the treatment zone at Grouse Creek and three sites outside of the treatment zone. At one of the sites in the treatment zone, Cluster Springs, there were two different springs (CLSP1 and CLSP2). CLSP1 was sampled during the first sampling event. During the second sampling event, CLSP1 was inadvertently overlooked, and CLSP2 was sampled. During the third sampling event, both CLSP1 and CLSP2 were sampled. At Ibapah, there were five sites inside and five sites outside of the treatment zone. At Vernon, there were four sites inside and five sites outside of the treatment zone. The sites in pesticide treatment zones were surrounded by a buffer zone extending $150 \mathrm{~m}$ from both sides of the water body. Some sites at Ibapah (ICST, IJCST, SDST) and Vernon (VD6ST, RCST) were not buffered because they are irrigation ditches and, therefore, were directly in the spray zone. The sites at Grouse Creek and Ibapah consisted of both springs and streams. All the sites at Vernon were classified as streams. Because the lower elevation sites at Vernon were areas that are ranched or farmed, these lower elevation areas also were the sites that were sprayed. Upper elevation sites at Vernon were not sprayed, potentially confounding the effects of spraying versus elevation on aquatic communities. Basic habitat characteristics were recorded at most sites. Water temperatures ranged from $4^{\circ} \mathrm{C}$ to $27^{\circ} \mathrm{C}$. Spring pools ranged in size from small $\left(20 \mathrm{~m}^{2}\right)$ to relatively large $\left(1,800 \mathrm{~m}^{2}\right)$. Streams were generally similar in size to each other, with wetted widths of 0.3 to $2.5 \mathrm{~m}$.

\section{Sampling Design}

We collected samples in three timeframes at Grouse Creek-before treatment, 2 weeks after treatment, and 4 months after treatment. Grouse Creek was the only area treated with diflubenzuron in 2005. Samples were collected only once, 1 year after treatment, at both Ibapah and Vernon.

\section{Sample Collection and Processing}

We collected macroinvertebrate samples by using a D-frame net (fig. 30). We targeted as many different habitat types as possible within each water body. These samples are semiquantitative, based on sampling effort. We recorded the amount of time spent sampling at each location and tailored the time to the size of the water body (that is, at the larger springs, such as Coal Mine Springs, we sampled for 10 minutes; but at Cluster Springs no. 1, which is much smaller, we sampled for 3 minutes). The samples were presorted in the field and preserved in ethanol.

\section{Sample Sorting and Identification}

All samples were sent to Rhithron Associates for identification and enumeration. Subsamples of a minimum of 300 organisms were obtained by using Caton subsampling devices, divided into 30 grids (each approximately 5 by $6 \mathrm{~cm}$ ). The organisms were identified to the lowest practical level con-

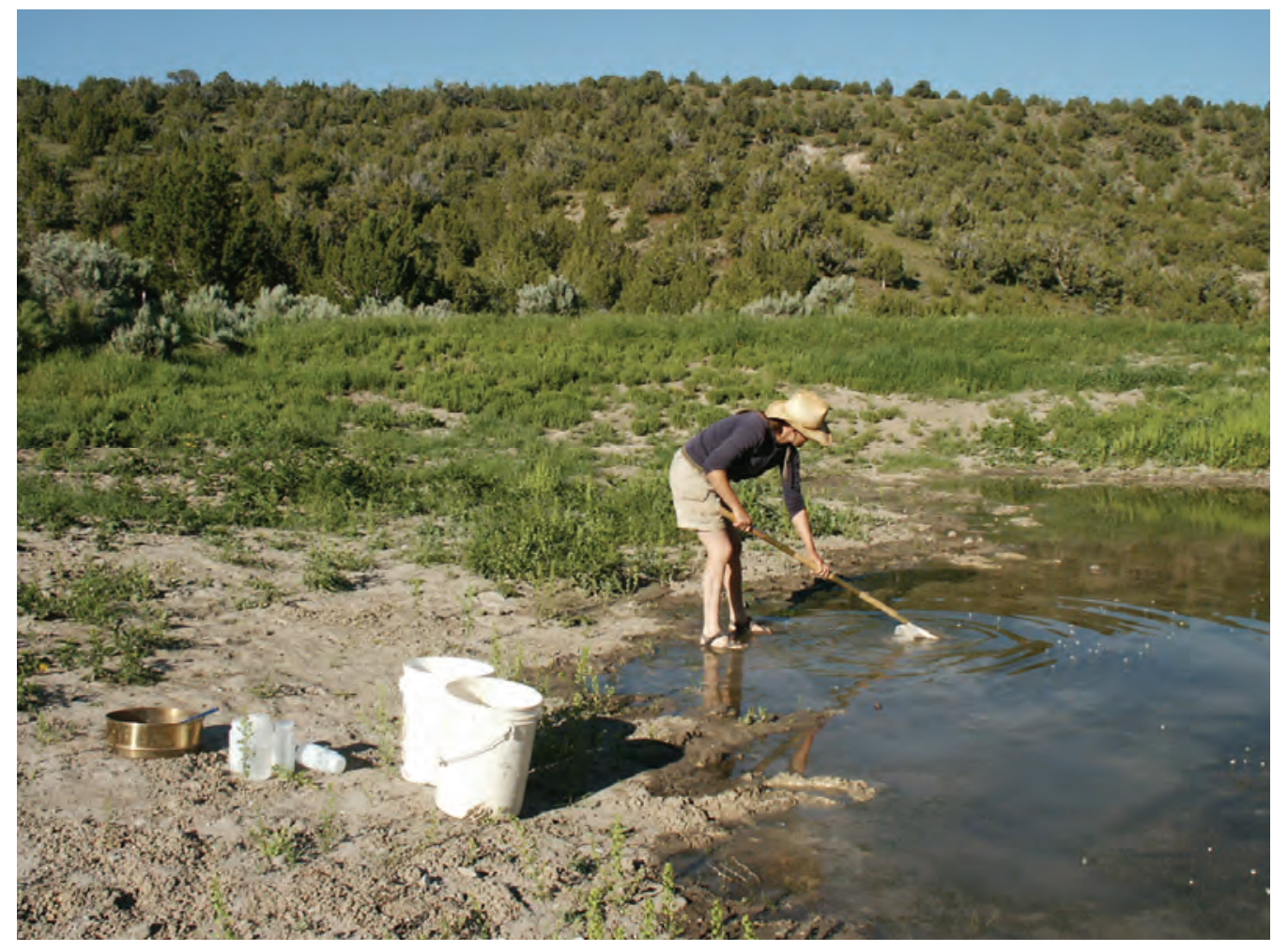

Figure 30. Collecting an aquatic macroinvertebrate sample using a D-frame net (U.S. Geological Survey photograph by Anne Brasher). 
sistent with Montana Department of Environmental Quality (DEQ) data requirements by using appropriate published taxonomic references. Quality-control procedures for taxonomy involved checking taxonomic accuracy and precision and enumeration accuracy.

\section{Data Analysis}

We used the Invertebrate Data Analysis System (Cuffney, 2003) for data management. Macroinvertebrate data were resolved for taxonomic ambiguities (by site) at the genus level, lifestages were combined, and coarser taxonomic levels were distributed to finer taxonomic levels. Rare taxa were retained. Standard metrics, including abundance, richness, and Shannon diversity were computed, and this dataset was used for subsequent analyses. This dataset was used for subsequent analyses. Multivariate procedures were conducted by using the statistical package PC-ORD (McCune and Mefford, 2005) to evaluate associations among species composition and sampling sites. Relative abundance data were used for NMS, which is a conglomerative technique that groups sites based on species composition (McCune and Grace, 2002). Results are presented as a bi-plot. In NMS, sites that are grouped more closely together have more species in common than sites that are distant from each other. Key species influencing the spread of sites along the axes are indicated on the bi-plot as vectors. The nonparametric Kruskall Wallis test was used with relative abundance and richness data to compare taxa from treated and untreated zones at each study area by using the statistical package S-PLUS (2000).

\section{Aquatic Results}

\section{Aquatic Macrofauna by Study Area}

We collected 169 different taxa at the three study areas (table 6), including 17 orders and 59 families. Appendix B provides a comprehensive taxa list (including abundances) at each sampling site. Grouse Creek was dominated by Tubificidae (tubificid worms), Cladocera (water fleas), Ostracoda (seed shrimp), Callibaetis mayflies, Enallagma damselflies, Pseudochironomus sp., Apedilum sp., and Micropsectra sp. midges, as well as Simulium sp. (blackfly larvae). Ibapah also was dominated by Tubificidae, Ostracoda, Callibaetis sp., Enallagma sp., and Simulium sp. In addition, Physa sp. snails, copepods (Maxillopoda/ Copepoda), amphipods, the mayflies Baetis tricaudatus and Epeorus longimanus, and midges Tvetenia bavarica gr. and Micropsectra sp. were abundant at Ibapah. One sampling site at Ibapah had more than 2,000 Fluminicola sp. snails. At Vernon, Ostracoda, Fluminicola sp., Pisidiidae (pea clams), the stonefly Zapada cinctipes, Baetis tricaudatus, Optioservus sp. (a beetle), Simulium sp., and the

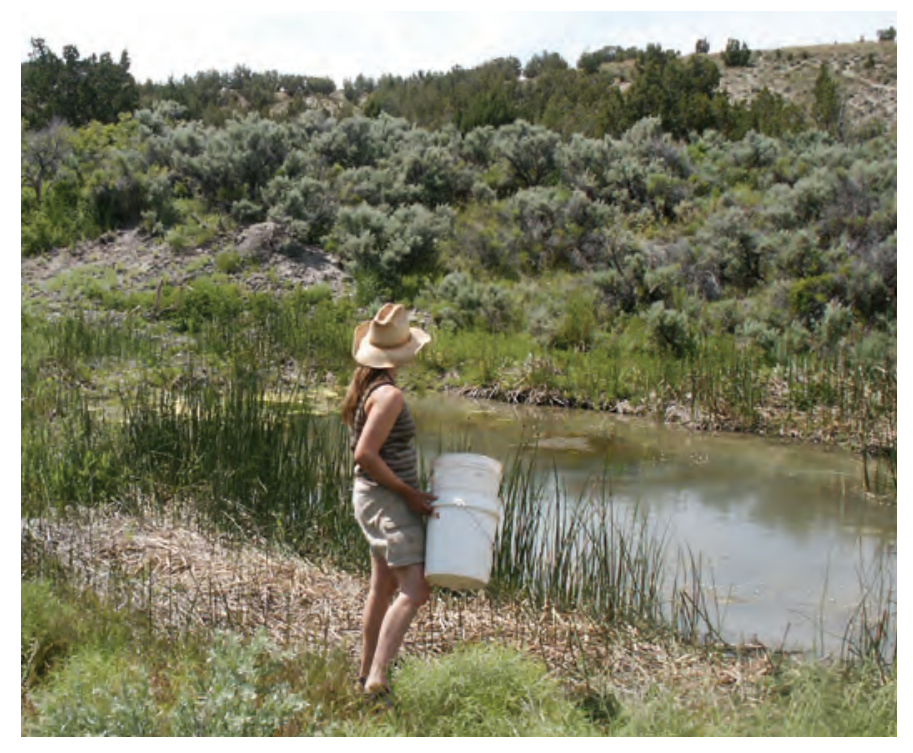

Figure 31. Cluster Spring 2 (CLSP2) at Grouse Creek, within the treated zone (U.S. Geological Survey photograph by Anne Brasher).

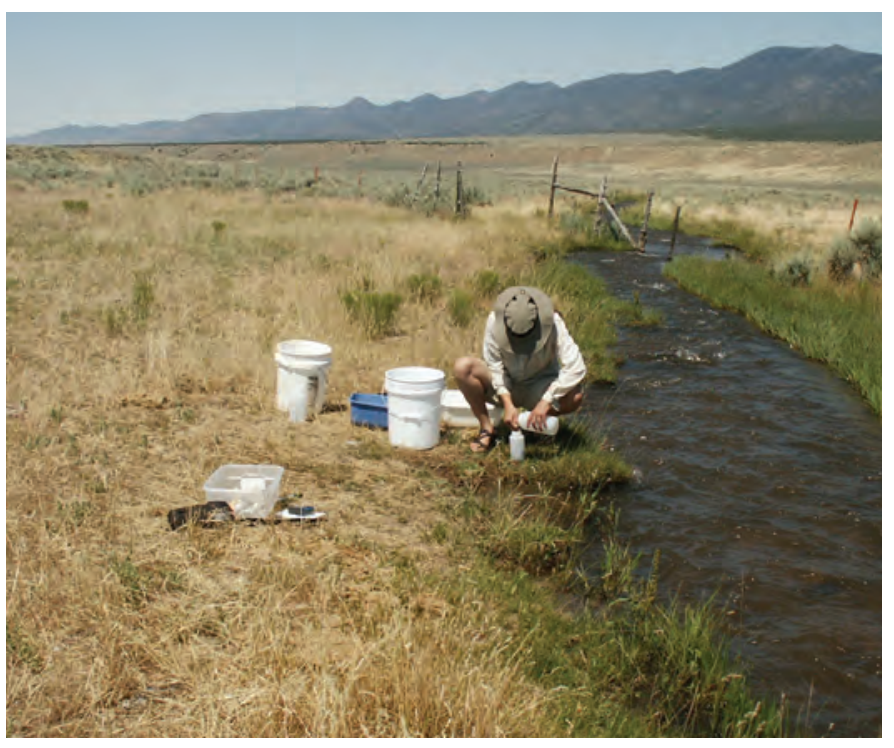

Figure 32. Aquatic macroinvertebrate sampling at one of the study streams (U.S. Geological Survey photograph by Anne Brasher).

midges Micropsectra sp., Tvetenia bavarica gr., Orthocladius sp., and Eukiefferiella claripennis gr. were the dominant taxa.

Water bodies at Grouse Creek and Ibapah consisted of both springs (fig. 31) and streams (fig. 32); only streams were sampled at Vernon. Overall, the macroinvertebrate fauna at springs was different than at streams. Crustaceans (Cladocera, Amphipoda, Maxillopoda, and Ostracoda) dominated springs, and mayflies (Ephemeroptera) and true flies (Diptera) dominated streams.

Approximately two-thirds of the taxa in springs at Grouse Creek (fig. 33A) and Ibapah (fig. 34B) consisted of crusta- 
Table 6. Aquatic taxa collected at the three west desert study areas, Utah.

\begin{tabular}{|c|c|c|c|c|c|c|c|c|c|c|}
\hline Phylum & Class & Order & Suborder & Family & Subfamily/Tribe & Genus/Species & Code & $\begin{array}{c}\text { Grouse } \\
\text { Creek }\end{array}$ & Ibapah & Vernon \\
\hline \multirow[t]{6}{*}{ Annelida } & Clitellata & Arhynchobdellida & Erpobdelliformes & Erpobdellidae & & Mooreobdella sp. & MOORE & & $X$ & $X$ \\
\hline & & & & & Erpobdellinae & Erpobdella sp. & ERPOB & & $\mathrm{X}$ & \\
\hline & & Haplotaxida & & Enchytraeidae & & & ENCHY & $\mathrm{X}$ & $\mathrm{X}$ & $\mathrm{X}$ \\
\hline & & & & Naididae & & & NAIDI & $\mathrm{X}$ & & $\mathrm{X}$ \\
\hline & & & & Tubificidae & & & TUBIF & $\mathrm{X}$ & $\mathrm{X}$ & $\mathrm{X}$ \\
\hline & & Rhynchobdellida & & Glossiphoniidae & Haementeriinae & Helobdella stagnalis & HELOB & & $\mathrm{X}$ & \\
\hline \multirow[t]{7}{*}{ Mollusca } & Bivalvia & Veneroida & & Pisidiidae & & & PISID & $X$ & $X$ & $X$ \\
\hline & Gastropoda & Basommatophora & & Lymnaeidae & & & LYMNA & $\mathrm{X}$ & & \\
\hline & & & & & & Fossaria sp. & FOSSA & $X$ & & $X$ \\
\hline & & & & & & Stagnicola sp. & STAGN & $X$ & $X$ & $\mathrm{X}$ \\
\hline & & & & Physidae & & Physa sp. & PHYSA & $X$ & $X$ & \\
\hline & & & & Planorbidae & & Gyraulus sp. & GYRAU & & $X$ & $X$ \\
\hline & & Neotaenioglossa & & Hydrobiidae & & Fluminicola sp. & FLUMI & $X$ & $X$ & $X$ \\
\hline Nematoda & & & & & & & NEMAT & $X$ & $X$ & $X$ \\
\hline \multirow[t]{2}{*}{ Platyhelminthes } & Turbellaria & & & & & & TURBE & $X$ & & $X$ \\
\hline & & Tricladida & & Planariidae & & Polycelis coronata & POLYC & & & $X$ \\
\hline \multirow[t]{5}{*}{ Arthropoda } & Arachnida & Trombidiformes & & & & & TROMB & $X$ & $X$ & $X$ \\
\hline & $\begin{array}{l}\text { Branchio- } \\
\text { poda }\end{array}$ & Diplostraca & Cladocera & & & & CLADOC & $X$ & $\mathrm{X}$ & \\
\hline & Malacostraca & Amphipoda & & Gammaridae & & Gammarus sp. & GAMMA & & $\mathrm{X}$ & $\mathrm{X}$ \\
\hline & & & & Hyalellidae & & Hyalella sp. & HYALE & $X$ & $X$ & $X$ \\
\hline & $\begin{array}{c}\text { Maxillopoda/ } \\
\text { Copepoda }\end{array}$ & & & & & & COPEP & $X$ & $X$ & $\mathrm{X}$ \\
\hline \multirow[t]{6}{*}{ Copepoda } & Ostracoda & & & & & & OSTRA & $\mathrm{X}$ & $\mathrm{X}$ & $\mathrm{X}$ \\
\hline & Insecta & Ephemeroptera & Furcatergalia & Caenidae & & Caenis sp. & CAENI & $X$ & & \\
\hline & & & & Ephemerellidae & & Drunella sp. & DRUNE & $\mathrm{X}$ & & \\
\hline & & & & & & Drunella grandis & DRUGR & $X$ & $X$ & \\
\hline & & & & & & Ephemerella inermis & INERM & $X$ & & $\mathrm{X}$ \\
\hline & & & & & Ephemerellinae & Serratella tibialis & SERRAT & $X$ & & \\
\hline
\end{tabular}


Table 6. Aquatic taxa collected at the three west desert study areas, Utah-Continued.

\begin{tabular}{|c|c|c|c|c|c|c|c|c|c|c|}
\hline \multirow[t]{22}{*}{ Phylum } & Class & Order & Suborder & Family & Subfamily/Tribe & Genus/Species & Code & $\begin{array}{l}\text { Grouse } \\
\text { Creek }\end{array}$ & Ibapah & Vernon \\
\hline & & & & Siphlonuridae & & & SIPHLO & $\mathrm{X}$ & & \\
\hline & & & & Baetidae & & Acentrella sp. & ACENT & $\mathrm{X}$ & & \\
\hline & & & & & & Baetis tricaudatus & BAETI & $\mathrm{X}$ & $\mathrm{X}$ & $\mathrm{X}$ \\
\hline & & & & & & Callibaetis sp. & CALLI & $\mathrm{X}$ & $\mathrm{X}$ & $\mathrm{X}$ \\
\hline & & & & & & Diphetor hageni & DIPHE & & $\mathrm{X}$ & $\mathrm{X}$ \\
\hline & & & Setisura & Heptageniidae & & Cinygmula sp. & CINYG & $\mathrm{X}$ & & \\
\hline & & & & & & Epeorus grandis & EGRAND & & $\mathrm{X}$ & \\
\hline & & & & & & Epeorus deceptivus & EDECEPT & & $\mathrm{X}$ & \\
\hline & & & & & & Epeorus longimanus & ELONGIM & $\mathrm{X}$ & $\mathrm{X}$ & \\
\hline & & Odonata & Anisoptera & Aeshnidae & & & AESHN & $\mathrm{X}$ & & \\
\hline & & & & & & Erythemis sp. & ERYTHEM & $\mathrm{X}$ & & \\
\hline & & & & & & Libellula sp. & LIBELSP & $\mathrm{X}$ & & \\
\hline & & & & & & Sympetrum sp. & SYMPE & $\mathrm{X}$ & $\mathrm{X}$ & \\
\hline & & & Zygoptera & Calopterygidae & & Hetaerina sp. & HETAER & & $\mathrm{X}$ & \\
\hline & & & & Coenagrionidae & & & COENAGR & $\mathrm{X}$ & & \\
\hline & & & & & & Amphiagrion sp. & AMPHIAG & $\mathrm{X}$ & & \\
\hline & & & & & & Enallagma sp. & ENALLAG & $\mathrm{X}$ & $\mathrm{X}$ & \\
\hline & & & & Lestidae & & Lestes sp. & LESTES & & $\mathrm{X}$ & \\
\hline & & Plecoptera & Euholognatha & Capniidae & & & CAPNII & $\mathrm{X}$ & & \\
\hline & & & & Nemouridae & & & NEMOU & $\mathrm{X}$ & & \\
\hline & & & & & Amphinemurinae & Malenka sp. & MALENKA & & $\mathrm{X}$ & \\
\hline
\end{tabular}


Table 6. Aquatic taxa collected at the three west desert study areas, Utah-Continued.

\begin{tabular}{|c|c|c|c|c|c|c|c|c|c|c|}
\hline Phylum & Class & Order & Suborder & Family & Subfamily/Tribe & Genus/Species & Code & $\begin{array}{c}\text { Grouse } \\
\text { Creek }\end{array}$ & Ibapah & Vernon \\
\hline & & & & & & Ochrotrichia sp. & OCHROT & $\mathrm{X}$ & $\mathrm{X}$ & $\mathrm{X}$ \\
\hline & & & & Rhyacophilidae & & Rhyacophila sp. & RHYACO & & & $\mathrm{X}$ \\
\hline & & Coleoptera & Adephaga & Dytiscidae & & & DYTISCI & $\mathrm{X}$ & $\mathrm{X}$ & $\mathrm{X}$ \\
\hline & & & & & & Agabus sp. & AGABU & $\mathrm{X}$ & $\mathrm{X}$ & \\
\hline & & & & & & Colymbetes sp. & COLYMB & $\mathrm{X}$ & & \\
\hline & & & & & & Rhantus sp. & RHANTU & $X$ & & \\
\hline & & & & & & Liodessus sp. & LIODESS & & $X$ & \\
\hline & & & & & & Hygrotus sp. & HYGROTU & & $X$ & \\
\hline & & & & & & Stictotarsus sp. & STICTOT & $X$ & $\mathrm{X}$ & $\mathrm{X}$ \\
\hline & & & & & & Laccophilus sp. & LACCOPH & $\mathrm{X}$ & & \\
\hline & & & & Haliplidae & & Peltodytes sp. & PELTODY & $\mathrm{X}$ & & \\
\hline & & & Polyphaga & Elmidae & & Cleptelmis sp. & CLEPTEL & & & $\mathrm{X}$ \\
\hline & & & & & & Optioservus sp. & OPTIOSE & $\mathrm{X}$ & $\mathrm{X}$ & $\mathrm{X}$ \\
\hline & & & & Hydraenidae & & Ochthebius sp. & OCHTHEB & $\mathrm{X}$ & & \\
\hline & & & & Hydrophilidae & & & HPHILID & $\mathrm{X}$ & $\mathrm{X}$ & \\
\hline & & & & & & Hydrobius sp. & HYBIUS & $\mathrm{X}$ & & \\
\hline & & & & & & Laccobius sp. & LACCOB & $\mathrm{X}$ & & \\
\hline & & & & & & Tropisternus sp. & TROPIST & $\mathrm{X}$ & & \\
\hline & & Diptera & Nematocera & Blephariceridae & Blepharicerinae & Agathon sp. & AGATH & $\mathrm{X}$ & & \\
\hline & & & & Ceratopogonidae & Ceratopogoninae & & CERATOP & $\mathrm{X}$ & $\mathrm{X}$ & $\mathrm{X}$ \\
\hline & & & & Chironomidae & Chironomini & Apedilum sp. & APEDILU & $X$ & $\mathrm{X}$ & \\
\hline & & & & & & Chironomus sp. & CHIRONO & $\mathrm{X}$ & & \\
\hline & & & & & & Chironomus sp. & CHIRONO & $X$ & & \\
\hline & & & & & & Parachironomus sp. & PARACHI & & & $\mathrm{X}$ \\
\hline & & & & & & Paracladopelma sp. & PARACLA & & & $\mathrm{X}$ \\
\hline & & & & & & Paratendipes sp. & PARATEN & $\mathrm{X}$ & $\mathrm{X}$ & \\
\hline & & & & & & Phaenopsectra sp. & PHAENOP & $\mathrm{X}$ & $\mathrm{X}$ & $\mathrm{X}$ \\
\hline & & & & & & Polypedilum sp. & POLYPED & $\mathrm{X}$ & $\mathrm{X}$ & $\mathrm{X}$ \\
\hline
\end{tabular}


Table 6. Aquatic taxa collected at the three west desert study areas, Utah-Continued.

\begin{tabular}{|c|c|c|c|c|c|c|c|c|c|c|}
\hline Phylum & Class & Order & Suborder & Family & Subfamily/Tribe & Genus/Species & Code & $\begin{array}{l}\text { Grouse } \\
\text { Creek }\end{array}$ & Ibapah & Vernon \\
\hline & & & & & $\begin{array}{l}\text { Pseudochirono- } \\
\text { mini }\end{array}$ & $\begin{array}{l}\text { Pseudochironomus } \\
\text { sp. }\end{array}$ & PSEUDOC & $\mathrm{X}$ & $\mathrm{X}$ & \\
\hline & & & & & Tanytarsini & & TARSINI & $\mathrm{x}$ & & \\
\hline & & & & & & Cladotanytarsus sp. & CLADOT & & $\mathrm{X}$ & \\
\hline & & & & & & Micropsectra sp. & MICROPS & $\mathrm{X}$ & $\mathrm{X}$ & $\mathrm{X}$ \\
\hline & & & & & & Rheotanytarsus sp. & RHEOTAN & $\mathrm{X}$ & & \\
\hline & & & & & & Stempellinella sp. & STEMPEL & $\mathrm{X}$ & & \\
\hline & & & & & & Tanytarsus sp. & TANYTAR & $\mathrm{X}$ & & $\mathrm{X}$ \\
\hline & & & & & Diamesinae & Pagastia sp. & PAGAS & $\mathrm{X}$ & $\mathrm{X}$ & $\mathrm{X}$ \\
\hline & & & & & & Pseudodiamesa sp. & IAMESA & & & $\mathrm{X}$ \\
\hline & & & & & & Diamesa sp. & DIAMES & $\mathrm{X}$ & & \\
\hline & & & & & Orthocladiinae & Acricotopus sp. & ACRICOT & $\mathrm{X}$ & & \\
\hline & & & & & & Brillia sp. & BRILLIA & $\mathrm{X}$ & & $\mathrm{X}$ \\
\hline & & & & & & Chaetocladius sp. & СHAETOC & $\mathrm{X}$ & & $\mathrm{X}$ \\
\hline & & & & & & Corynoneura sp. & CORYNON & $\mathrm{x}$ & $\mathrm{X}$ & $\mathrm{X}$ \\
\hline & & & & & & $\begin{array}{l}\text { Cricotopus } \\
\quad \text { (Cricotopus) }\end{array}$ & CRICOTO & $\mathrm{x}$ & $\mathrm{X}$ & $\mathrm{X}$ \\
\hline & & & & & & $\begin{array}{l}\text { Cricotopus } \\
\quad \text { (Isocladius) }\end{array}$ & ISOCLAD & $\mathrm{X}$ & & \\
\hline & & & & & & $\begin{array}{l}\text { Eukiefferiella brehmi } \\
\mathrm{gr} .\end{array}$ & EUKBREH & $\mathrm{X}$ & $\mathrm{X}$ & $\mathrm{X}$ \\
\hline & & & & & & $\begin{array}{l}\text { Eukiefferiella } \\
\text { devonica gr. }\end{array}$ & EUKDEVO & & $\mathrm{X}$ & $\mathrm{X}$ \\
\hline & & & & & & $\begin{array}{l}\text { Eukiefferiella gracei } \\
\text { gr. }\end{array}$ & EUKGRAC & & $\mathrm{X}$ & $\mathrm{X}$ \\
\hline & & & & & & $\begin{array}{l}\text { Eukiefferiella clarip- } \\
\text { ennis gr. }\end{array}$ & EUKCLAR & & $\mathrm{X}$ & $\mathrm{X}$ \\
\hline & & & & & & Limnophyes sp. & LIMNOP & $\mathrm{X}$ & $\mathrm{x}$ & $\mathrm{X}$ \\
\hline & & & & & & Orthocladius sp. & ORTHOC & $\mathrm{X}$ & $\mathrm{X}$ & $\mathrm{X}$ \\
\hline & & & & & & Parakiefferiella sp. & PARAKI & & & $\mathrm{X}$ \\
\hline & & & & & & $\begin{array}{l}\text { Parametriocnemus } \\
\text { sp. }\end{array}$ & PARAME & $\mathrm{X}$ & & $\mathrm{x}$ \\
\hline
\end{tabular}


Table 6. Aquatic taxa collected at the three west desert study areas, Utah-Continued.

\begin{tabular}{|c|c|c|c|c|c|c|c|c|c|c|}
\hline Phylum & Class & Order & Suborder & Family & Subfamily/Tribe & Genus/Species & Code & $\begin{array}{c}\text { Grouse } \\
\text { Creek }\end{array}$ & Ibapah & Vernon \\
\hline & & & & & & $\begin{array}{l}\text { Paraphaenocladius } \\
\text { sp. }\end{array}$ & PARAPH & $\mathrm{X}$ & & \\
\hline & & & & & & Psectrocladius sp. & PSECTRC & $\mathrm{X}$ & $X$ & \\
\hline & & & & & & Pseudosmittia sp. & PSEUDOS & $X$ & & \\
\hline & & & & & & Rheocricotopus sp. & RHEOCRI & & & $X$ \\
\hline & & & & & & Thienemanniella sp. & THIENEM & & $X$ & \\
\hline & & & & & & $\begin{array}{l}\text { Tvetenia bavarica } \\
\quad g r .\end{array}$ & TVETE & $X$ & $\mathrm{X}$ & $X$ \\
\hline & & & & & & Metriocnemus sp. & METRIOC & $\mathrm{X}$ & $\mathrm{X}$ & $\mathrm{X}$ \\
\hline & & & & & Podonominae & Parochlus sp. & PAROC & & & $\mathrm{X}$ \\
\hline & & & & & Prodiamesinae & Odontomesa sp. & ODONTO & & $X$ & $\mathrm{X}$ \\
\hline & & & & & & Prodiamesa sp. & PRODIA & & & $X$ \\
\hline & & & & & Tanypodinae & & TANYPOD & $X$ & & \\
\hline & & & & & & Apsectrotanypus sp. & APSECTR & & $\mathrm{X}$ & $\mathrm{X}$ \\
\hline & & & & & & Psectrotanypus sp. & PSECTRT & & $X$ & \\
\hline & & & & & & Radotanypus sp. & RADOTA & & $X$ & $\mathrm{X}$ \\
\hline & & & & & & Pentaneura sp. & PENTA & $X$ & $X$ & \\
\hline & & & & & & $\begin{array}{l}\text { Thienemannimyia } \\
\quad g r .\end{array}$ & NIMYIA & $\mathrm{X}$ & $X$ & $X$ \\
\hline & & & & & & Zavrelimyia sp. & ZAVRELI & $X$ & $X$ & \\
\hline & & & & & & Tanypus sp. & TANYPUS & & $\mathrm{X}$ & \\
\hline & & & & Culicidae & & & CULICI & $\mathrm{X}$ & $\mathrm{X}$ & $\mathrm{X}$ \\
\hline & & & & Dixidae & & & DIXID & & $\mathrm{X}$ & \\
\hline & & & & & & Dixa sp. & DIXASP & & & $\mathrm{X}$ \\
\hline & & & & & & Meringodixa sp. & MERINGO & $\mathrm{X}$ & & \\
\hline & & & & Psychodidae & & & PSYCHOD & $X$ & & $X$ \\
\hline & & & & Simuliidae & & Prosimulium sp. & PROSIMU & $\mathrm{X}$ & $\mathrm{X}$ & \\
\hline & & & & & & Simulium sp. & SIMULIU & $\mathrm{X}$ & $\mathrm{X}$ & $\mathrm{X}$ \\
\hline & & & & Tipulidae & Limoniinae & Molophilus sp. & MOLOPH & & $X$ & \\
\hline & & & & & & Pedicia sp. & PEDICI & & & $\mathrm{X}$ \\
\hline & & & & & & Dicranota sp. & DICRAN & & & $\mathrm{X}$ \\
\hline
\end{tabular}


Table 6. Aquatic taxa collected at the three west desert study areas, Utah—Continued.

\begin{tabular}{|c|c|c|c|c|c|c|c|c|c|c|}
\hline Phylum & Class & Order & Suborder & Family & Subfamily/Tribe & Genus/Species & Code & $\begin{array}{c}\text { Grouse } \\
\text { Creek }\end{array}$ & Ibapah & Vernon \\
\hline & & & Brachycera & Dolichopodidae & & & DOLICHO & $\mathrm{x}$ & & \\
\hline & & & & & & Neoplasta sp. & NEOPLAS & & & $\mathrm{X}$ \\
\hline & & & & & & Clinocera sp. & CLINOCE & $\mathrm{X}$ & $\mathrm{X}$ & $\mathrm{X}$ \\
\hline & & & & Ephydridae & & & EPHYDR & $\mathrm{x}$ & & \\
\hline & & & & Sciomyzidae & & & SCIOMYZ & $\mathrm{X}$ & $\mathrm{X}$ & \\
\hline
\end{tabular}


ceans. Diptera and noninsect taxa (mites, nematodes, and oligochaetes) made up about one quarter of the noncrustacean taxa in springs at Grouse Creek. Insects (Ephemeroptera, Diptera, and other insects) made up a little more than one-fifth of the taxa in springs at Ibapah, with molluscs accounting for an additional tenth. Diptera in springs at Grouse Creek and Ibapah were almost entirely Chironomidae.

Streams at Grouse Creek (fig. 33B), Ibapah (fig. 34B), and Vernon (35) had fairly similar relative abundances of different taxa at the order level. Diptera was the most abundant, followed by Ephemeroptera. Together, these two orders accounted for 95 percent, 82 percent, and 80 percent of the taxa in streams at Grouse Creek, Ibapah, and Vernon, respectively. More than three-quarters of the Diptera in streams at Grouse Creek were Simulidae; most of the remaining Diptera were Chironomidae. The opposite pattern was observed at Ibapah and Vernon, with approximately three-quarters of the Diptera consisting of Chironomidae. Crustaceans and molluses contributed little to the overall abundance at Grouse Creek and Ibapah streams (less than 5 percent), while 12 percent of the abundance in Vernon streams consisted of crustaceans and molluscs. Vernon streams had half as many mayflies as streams in Grouse Creek and Ibapah.

\section{Richness, Abundance, and Diversity at Sampling Sites in the Three Study Areas}

\section{Grouse Creek}

Grouse Creek was the only study area sprayed in 2005. There was no significant difference in abundance (Kruskall Wallis chi-square $=0.4176 ; P=0.5181$ ) or richness (Kruskall Wallis chi-square $=1.5578 ; P=0.212$ ) between sites inside and outside the treatment zones after treatment. Because water bodies were buffered (no pesticide was sprayed closer than about $150 \mathrm{~m}$ from a water body), the lack of difference between sprayed and unsprayed sites was not unexpected. At Grouse Creek, abundance (number of individuals) was highly variable among sites, with no clear pattern between the treated and untreated zones (fig. 36). Richness (number of taxa) was less variable among sites. The diversity index mirrors the richness values. Since there was no statistically significant difference in macroinvertebrate abundance or richness between the treated and untreated zones after treatment, all sampling dates (before and after treatment) were plotted for further commu-

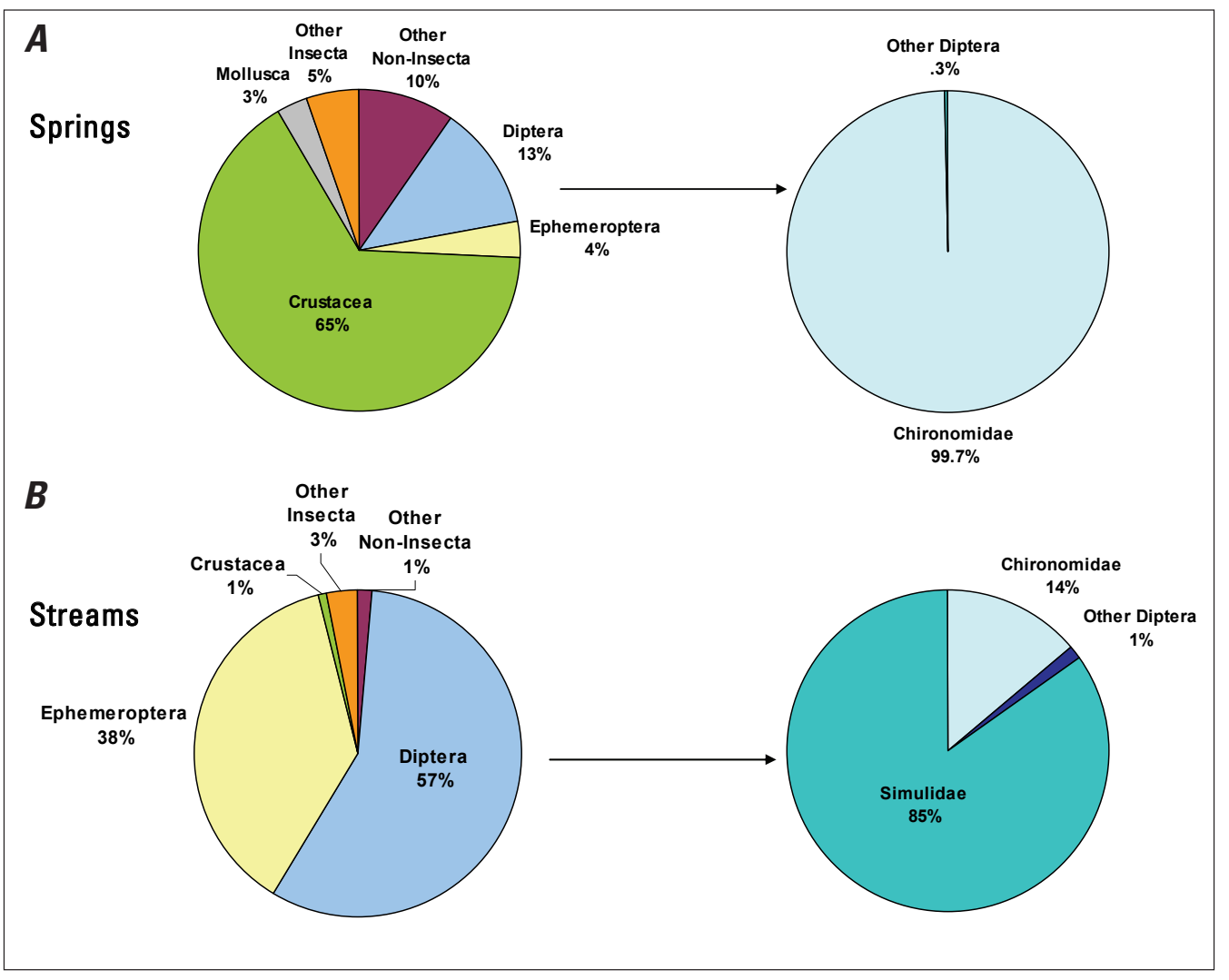

Figure 33. Relative abundances of aquatic taxa in springs $(A)$ and streams $(B)$ at the Grouse Creek study area. 
Figure 34. Relative abundances of aquatic taxa in springs $(A)$ and streams $(B)$ at the Ibapah study area.
Figure 35. Relative abundances of aquatic taxa in streams at the Vernon study area.
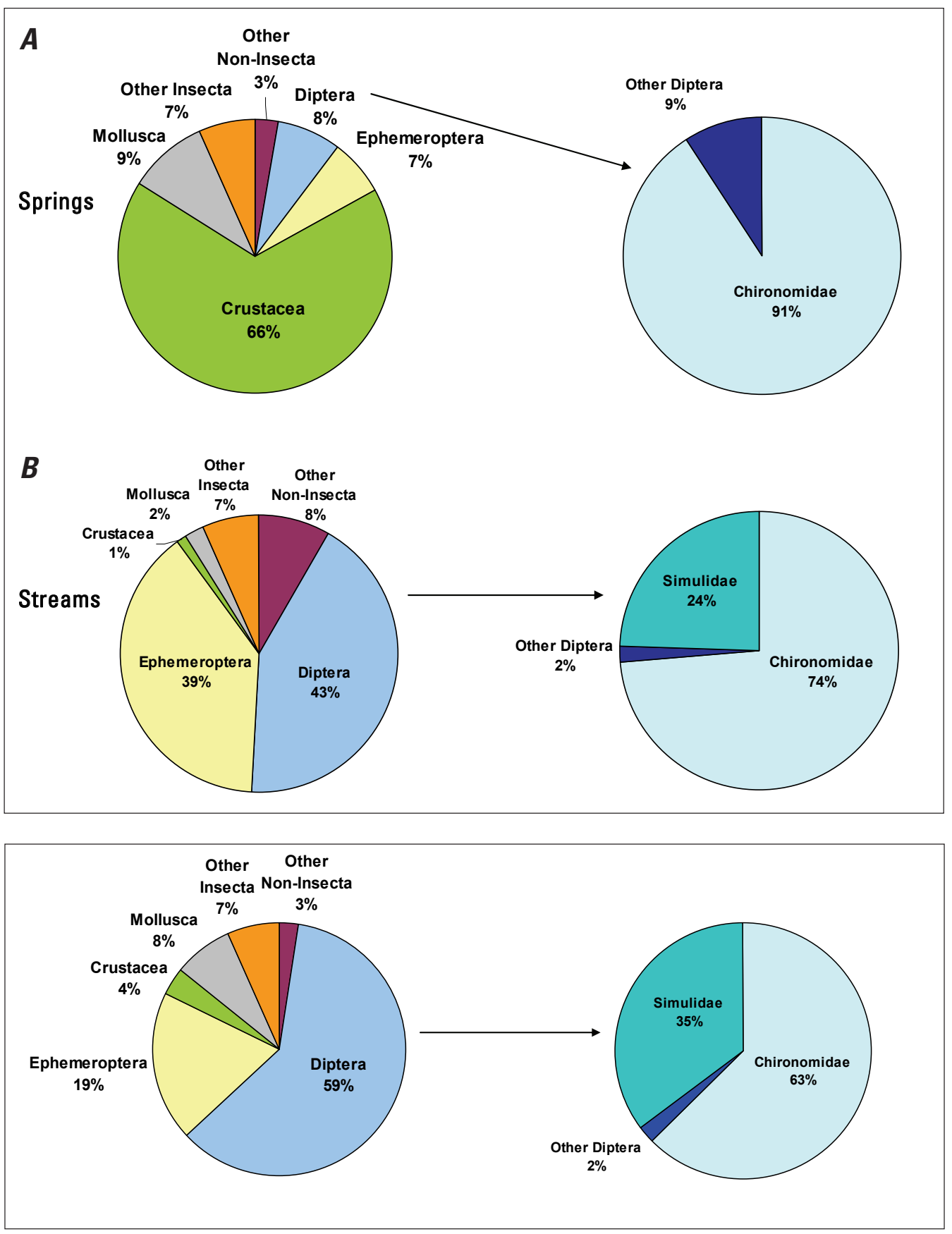

nity analysis (fig. 37). The lowest abundance in the untreated zone was at Keg Springs, which was sampled in May 2005; and the highest abundance in the untreated zone was at this same sampling site in October 2005. This high abundance was in large part due to the presence of 7,306 individual Cladocera in the sample. Seasonal changes in species composition and abundance are further addressed in the section discussing preand post-treatment aquatic communities.

\section{Ibapah}

Ibapah was sprayed in 2004 but not 2005 (the year we sampled). There was no significant difference in abundance
(Kruskall Wallis chi-square $=0.5345 ; P=0.4647$ ) or richness (Kruskall Wallis chi-square $=1.866 ; P=0.1719$ ) between sites inside and outside of the treatment zone. Richness was fairly consistent across all sites (fig. 38). Sites outside the treatment zone at Ibapah included two streams and three springs; inside the treatment zone, we were able to locate and sample streams but no springs. The difference in habitat type may confound the analysis of pesticide effect on abundance because the three springs (all outside of the treatment zone) had substantially higher abundance than any of the streams. One spring site (SKSP) had more than 27,000 individuals (of these, 21,086 were Ostracoda), a second spring site (SOXSP) had almost 10,000 individuals (with no taxa particularly dominant), and 
a third spring site (NOXSP) had more than 5,000 individuals (with no taxa particularly dominant). The next most abundant sample was 2,550 individuals at a stream site within the treatment zone. The remaining stream sites had less than 1,700 individuals.

\section{Vernon}

Vernon also was sprayed in 2004 but not in 2005. All sampling sites at Vernon were classified as streams for this study. However, some sites were streams (and, thus, were buffered from spraying) and some were ditches (and were not buffered from spraying). There was no significant difference in abundance (Kruskall Wallis chi-square $=1.5 ; P=0.2207$ ) between sites inside and outside of the treatment zone, even considering ditches versus streams. Again, abundance was highly variable among sites in both the treated and untreated zones (fig. 39). Two sites outside the treatment zone each had approximately 20,000 individuals. More than half of the individuals at LFST $(11,743)$ were Micropsectra sp. midges. Abundance was fairly evenly distributed among taxa at PCST, with the two most dominant taxa being Simulium sp. and Micropsectra sp. The next largest abundances were approximately 10,000 individuals each at one treated site and one untreated site.

Richness was significantly higher (Kruskall Wallis chisquare $=6.0504 ; P=0.0139)$ in the untreated zone than in the treated zone, and higher in the actual streams than in the ditches. This may indicate an effect of pesticide spraying, but the difference in elevation again confounds this interpretation. Sites in untreated zones at Vernon had elevations ranging from 597 to $644 \mathrm{~m}$, and sites in treatment zones ranged in elevation from 532 to $576 \mathrm{~m}$. This elevation gradient also represents a gradient in habitat quality that would influence community composition.

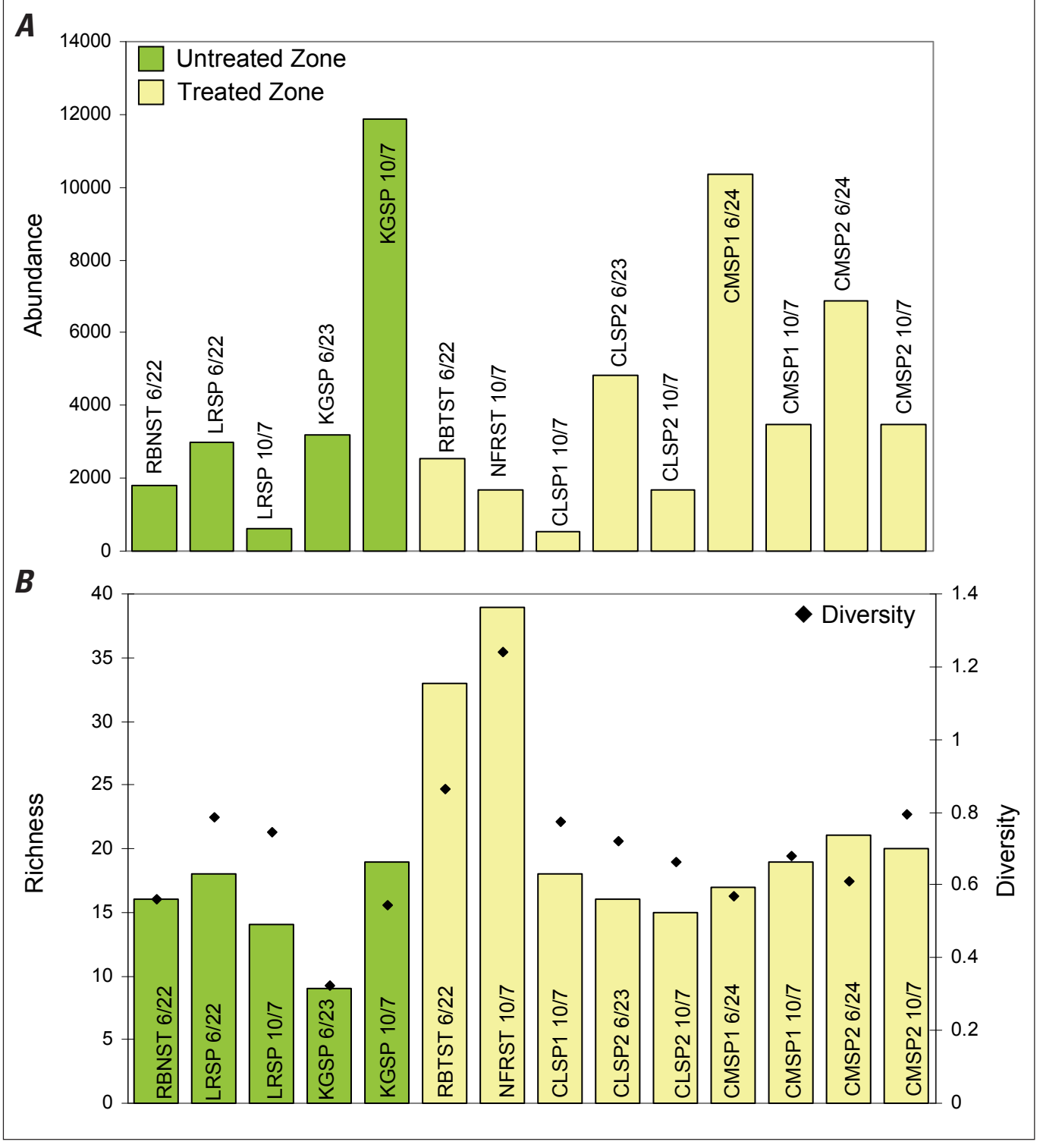

Figure 36. Taxa abundance $(A)$ and richness and diversity $(B)$ inside and outside diflubenzuron treatment zones at Grouse Creek, only after treatment. 


\section{Macroinvertebrates in the Grouse Creek Treatment Zone}

Grouse Creek, the only study area treated in 2005, was sampled three times during this study. We sampled before treatment, 2 weeks after treatment, and 4 months after treatment. Sampling site RBTST was dried up 3 months after treatment, so we were unable to sample there. We also did not sample at CLSP1 2 weeks after treatment. Generally, abundance and richness increased from pre-treatment samples to 2-week post-treatment samples, and decreased from 2-week post-treatment samples to 3-month post-treatment samples (fig. 40). This pattern of changing abundance and richness is most likely due to natural temporal variation, whereby aquatic invertebrate populations peak in the month of June and their populations decrease again with colder weather in October. Consequently, evaluation of any effects of diflubenzuron application is confounded by temporal phenology (change during the season) in aquatic communities.

\section{Aquatic Community Structure}

We used NMS to evaluate community structure at the three study areas. The NMS was run on relative abundance data using the Sorensen distance measure, allowing a maximum number of 6 axes (dimensions). A two-dimensional solution was selected as the best-fit model.

In an NMS plot, sites with similar taxa plot close to each other. Results of the NMS analysis generated two major groupings, stream communities and spring communities (fig. 41). Cladocera, Callibaetis sp., Enallagma sp., Sympetrum sp., Notonecta sp., Erythemis sp., and Ostracoda are characteristic of springs. Baetis tricaudatus, Pagastia sp., Ameletus sp., Micropsectra sp., and Simulium sp. are characteristic of streams. Ostracoda grouped the Grouse Creek spring samples taken in May and June with one Ibapah spring (SKSP), while the other spring-driven species listed above grouped the Grouse Creek springs collected in October with the other two Ibapah springs, NOXSP and SOXSP. Ibapah streams grouped separately from Grouse Creek and Vernon streams.
Figure 37. Taxa abundance $(A)$ and richness and diversity $(B)$ inside and outside diflubenzuron treatment zones at Grouse Creek, all sampling dates included.

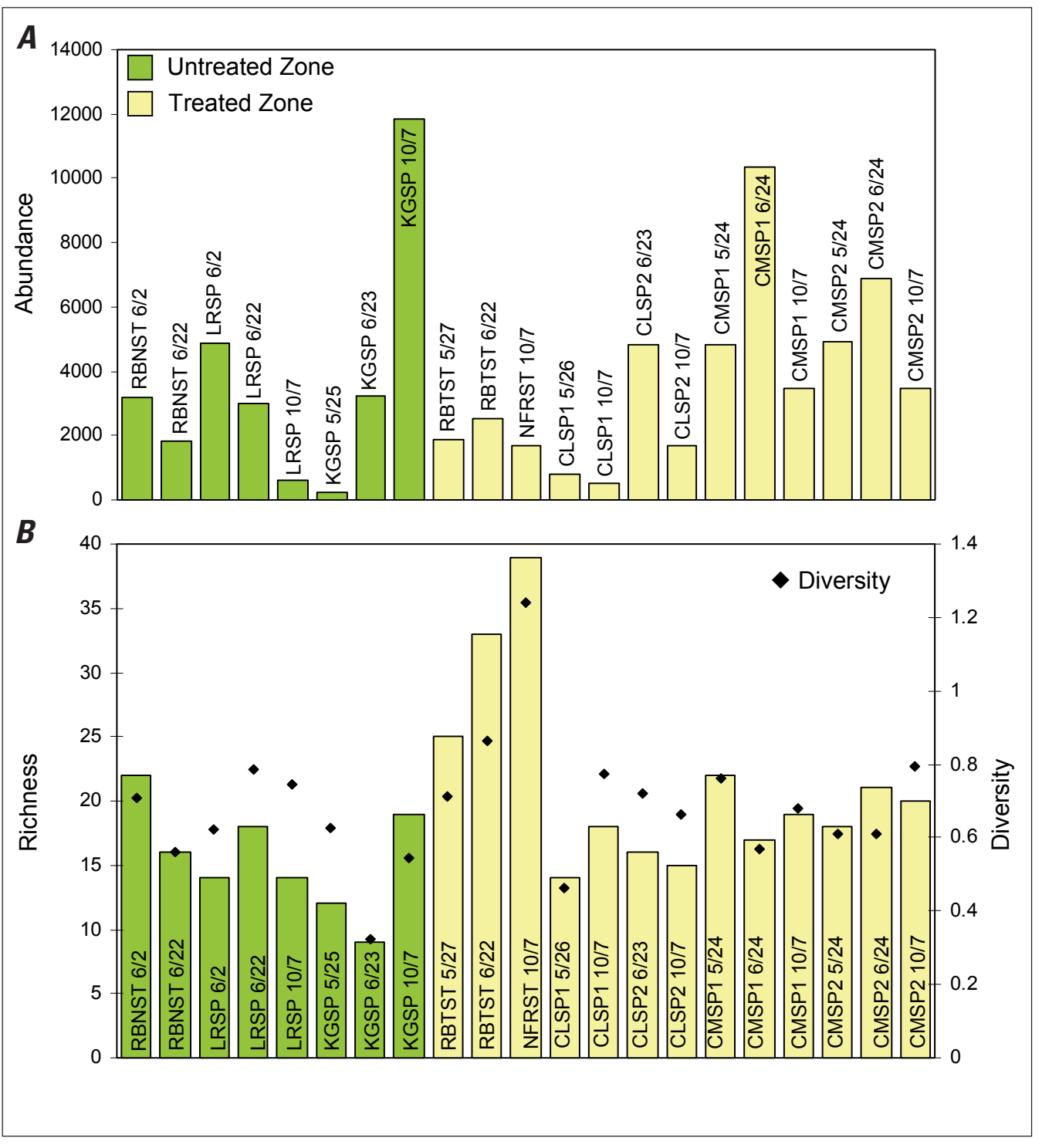




\section{Discussion}

\section{Terrestrial Study}

Our results indicate that nontarget arthropods vary considerably in susceptibility to diflubenzuron when used to control Mormon cricket populations in the Great Basin. Sensitivity to diflubenzuron is not necessarily predictable on a taxonomic basis or on an assessment of life history traits. Our data indicate that some taxa assumed not to be susceptible did have population differences that correlated with treatment zones. The importance of identifying specimens to the lowest possible taxonomic level in analyzing results should be emphasized, as conclusions may be very different depending on how the arthropods are classified (for example, counts at family versus genus level). A total of 42 comparisons of untreated abundance versus treated abundance were possible for the three study areas. Nine of these comparisons showed significant differences between treatment zones; another nine comparisons indicated large, but not statistically significant, differences. In all 18 instances, more individuals were collected in the untreated zone.

At the order level, no consistent patterns of difference in proportional representation between treated and untreated sites at any of the three study areas indicate that treatment with diflubenzuron affects nontarget arthropods. Our results are not conclusive, however, because there is tremendous variation between individual sites within each treatment type, and because order-level resolution may mask changes in communities at lower taxonomic levels. For example, shifts between genera or from one family to another may not be detected if one taxon replaces another with a similar number of individuals. In addition, there may have been confounding effects from

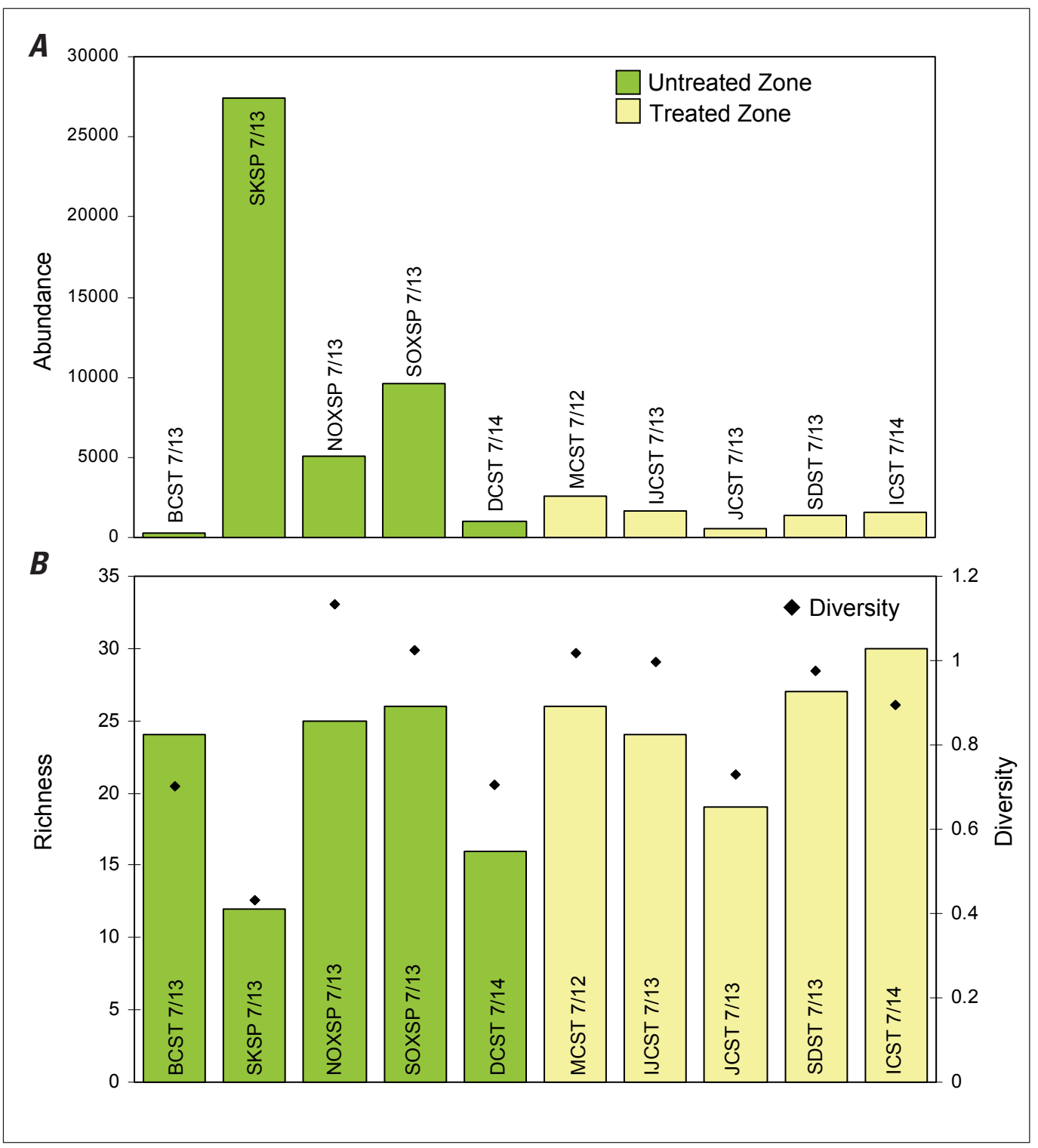

Figure 38. Taxa abundance $(A)$ and richness and diversity $(B)$ inside and outside diflubenzuron treatment zones at Ibapah. 
topography and other issues with the spatial distribution of treated and untreated sites due to the nature of Mormon cricket treatment applications in general.

Studies conducted in South Dakota and Wyoming found diflubenzuron had minimal impacts on nontarget arthropods and their vertebrate predators (Wilcox and Coffey, 1978; McEwen and others, 1996), indicating that use of diflubenzuron in a reduced agent-area treatment design (by using less pesticide in alternating swaths) would have less environmental impact than carbaryl or malathion. However, some taxon-specific effects have been recorded. Catangui and others (2000) reported temporary declines in ants, "flying predators," and "parasites." Weiland and others (2002) reported that Diptera increased significantly and spider numbers were reduced in treated plots in a Wyoming study. Smith and others (2006) found that for some applications, numbers decreased at low pesticide-application rates, but abundance was greater at higher pesticide-application rates. Studies indicating diflubenzuron had limited impacts on nontarget arthropods and was effective at low-application rates were conducted in the Great
Plains, but additional information that is directly applicable to the environment of Utah's west desert is needed.

Catangui and others (2000) found that ants in pitfall traps declined by 43 percent 49 to 55 days after treatment, but subsequent sampling periods showed a rebound to pre-treatment numbers. Smith and others (2006) reported that Formicidae as a family showed mixed responses in a Wyoming study of nontarget arthropod responses to treatments of carbaryl and diflubenzuron at different dose rates and carrier oils. Ants were reduced in diflubenzuron treatments relative to carbaryl treatments using the same carrier oil in 2001, but no significant differences between the two treatments were found in 2002. Weilund and others (2002) reported no response at the order level by Hymenoptera to diflubenzuron applications in Wyoming.

Grouped at the family level, ants did not show declines in treated zones at any of our study areas. In fact, more ants were collected at Ibapah sprayed sites than at unsprayed sites, and at Grouse Creek more ants were collected in the sprayed zone 3 weeks after diflubenzuron application than were col-
Figure 39. Taxa abundance $(A)$ and richness and diversity $(B)$ inside and outside diflubenzuron treatment zones at Vernon.

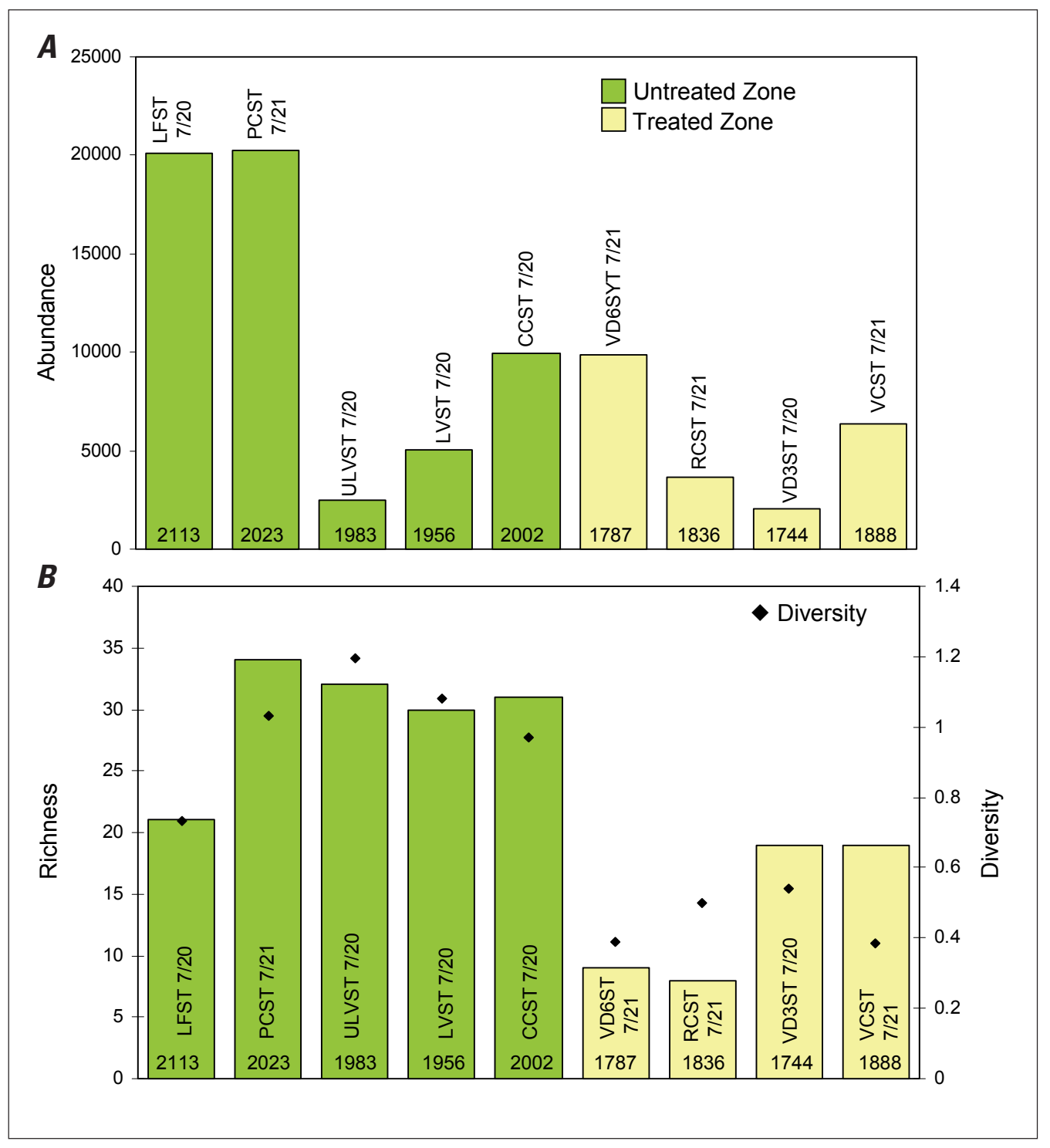


lected prior to treatment. However, when examined at the genus level, differences in abundance were correlated with diflubenzuron treatment. Some genera (for example, Forelius) had higher numbers in sprayed zones, while the abundance of other genera (for example, Tapinoma) was lower in sprayed zones. Potential indicators in the ant communities we sampled include genera that appear to decrease in response to diflubenzuron treatment and those that increase. Formica and Tapinoma tended to have lower numbers in treated zones, while Forelius and perhaps Pheidole tended to increase in treated zones.

Ants perform a number of important ecological functions, especially in arid and semiarid ecosystems (Greenslade, 1976; Risch and Carroll, 1982; Lobry de Bruyn and Conacher, 1990; Lobry de Bruyn and Conacher, 1994; Nash and others, 1998; Whitford and others, 1999). Predictions of the sensitivity of ants to environmental perturbations and restorations and, thus, their value as bioindicators have not been consistently supported (Bestelmeyer and Wiens, 1996; Whitford and others, 1999; Read and Andersen, 2000; Nash and others, 2001; Andersen and others, 2002; Andersen and Majer, 2004; Nash and others, 2004). Because ants perform significant functions in ecosystems, it is important to understand how individual species and collective units at functional group and community levels respond to disturbance, and how they recover from perturbation in the short and long term.

Diflubenzuron may be a factor in developing ant community structure at Ibapah and Vernon. However, pesticide treatments could be correlated with other environmental factors we did not measure that made these sites favorable for Forelius and, perhaps, less favorable for Formica and Tapinoma. There are potential confounding effects of topography based on where and how diflubenzuron was applied. Ibapah treated sites were all south of untreated sites, and most were a little higher in elevation. These conditions were reversed at Vernon, however, where untreated sites were higher and south of the treated area; elevation differences were greater at Vernon than at Ibapah. Similarities among ant communities from treated zones at Ibapah and Vernon, despite environmental differences between them, suggest a role for diflubenzuron in structuring ant communities in the treated zones. Untreatedzone communities at Ibapah and Vernon study areas differed; each untreated site within the Ibapah and Vernon study areas had different ant communities (fig. 21). Convergence of

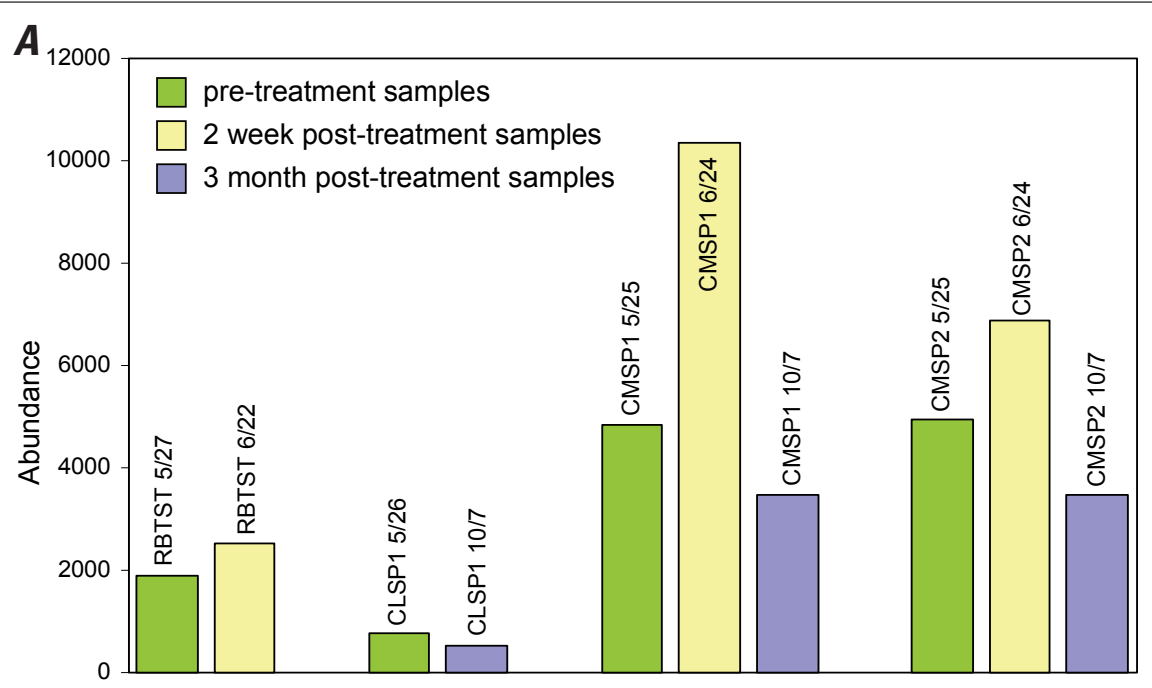

B

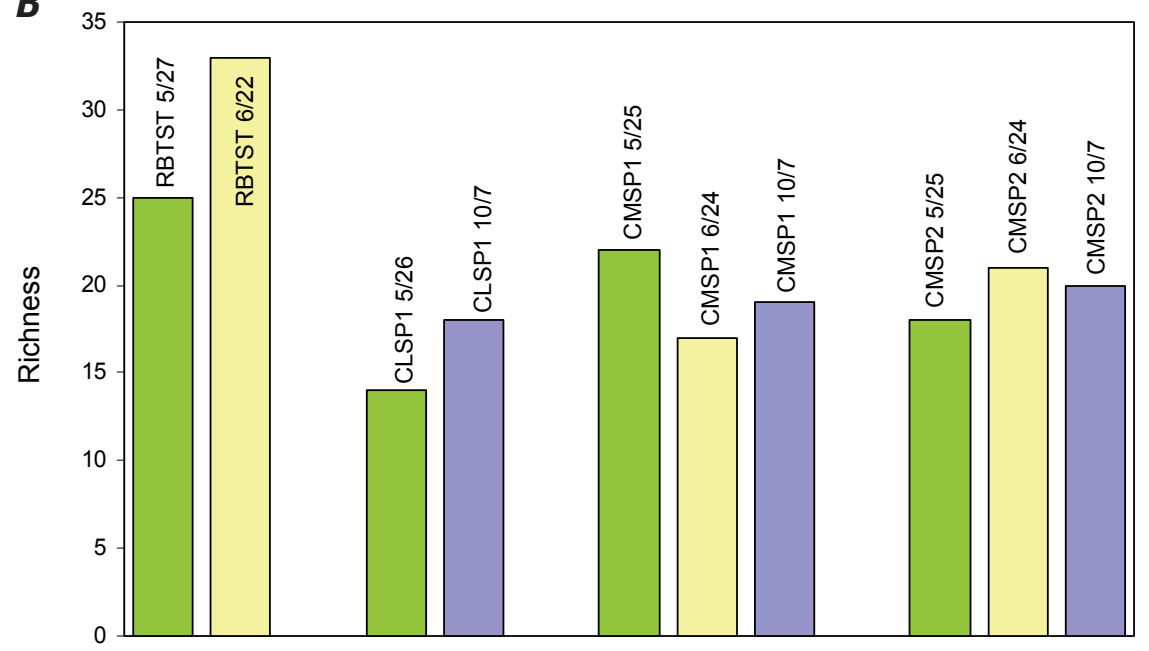

Figure 40. Taxa abundance $(A)$ and richness $(B)$ before diflubenzuron treatment, 2 weeks after treatment, and 4 months after treatment, at the Grouse Creek study area. 
communities in the treated zones indicates a possible link to diflubenzuron treatment. Additional research is needed, especially a study designed to address the possibility of lag effects of diflubenzuron on the ant communities, and ants should be identified to species level to elucidate ecological functions that might be affected by changes in ant community structure in response to diflubenzuron application.

Non-ant Hymenoptera (including bees and predatory and parasitic wasps) were significantly lower in treated zones at Grouse Creek and Vernon. Coleoptera demonstrated the same pattern as non-ant Hymenoptera, with significantly fewer beetles at treated sites at Vernon and a trend toward more beetles at untreated sites in the Ibapah study area. Flies also were significantly reduced at Vernon and showed a trend toward declining numbers at treated sites at Ibapah. Catangui and others (2000) reported that diflubenzuron reduced the number of flying predators by 59 percent 15 to 20 days after treatment, however, numbers rebounded in subsequent samples. Parasite numbers also were reduced (by about 18 percent) 35 to 41 days after treatment, but abundance returned to near-control levels after 41 days (Catangui and others, 2000). Flying insects classified as parasites included both Hymenoptera and Diptera; flying insects classified as predators included Hymenoptera, Diptera, and Coleoptera (Catangui and others, 2000).
Hemiptera showed large differences in abundance among sites, and large changes over time were observed at Grouse Creek. Some differences were correlated with treatment zone; more Hemiptera and more of particular families were found in the untreated zones in all three study areas. Smith and others (2006) found the Hemiptera had mixed responses to various treatments, but some diflubenzuron treatments did reduce Hemiptera numbers.

Within the Hemiptera, there was some indication that the Lygaeidae (seed bugs), in particular, were sensitive to diflubenzuron treatments. Lygaeidae were absent at Grouse Creek from all late May and early June samples, probably because of phenology. No seed bugs were found in any traps from treated sites during the late June collection period, but they were caught consistently, albeit at low numbers, in the untreated zone during this sampling period. The seed bugs at Grouse Creek and Ibapah showed a trend toward reduced numbers in the treated zones; differences in numbers of seed bugs between zones were significant at both study areas. There were large differences in total numbers of seed bugs at Vernon (63 in the untreated zone, 32 in the treated zone), but the differences were not significant because of high variability among sites. Seed bugs represented a relatively small component of the arthropod community at all three study areas. The
Figure 41. Nonmetric multidimensional scaling joint plot with aquatic macroinvertebrate relative taxa abundances. Dark green, Grouse Creek springs; light green, Ibapah springs; dark blue, Grouse Creek streams; light blue, Ibapah streams; purple, Vernon streams.

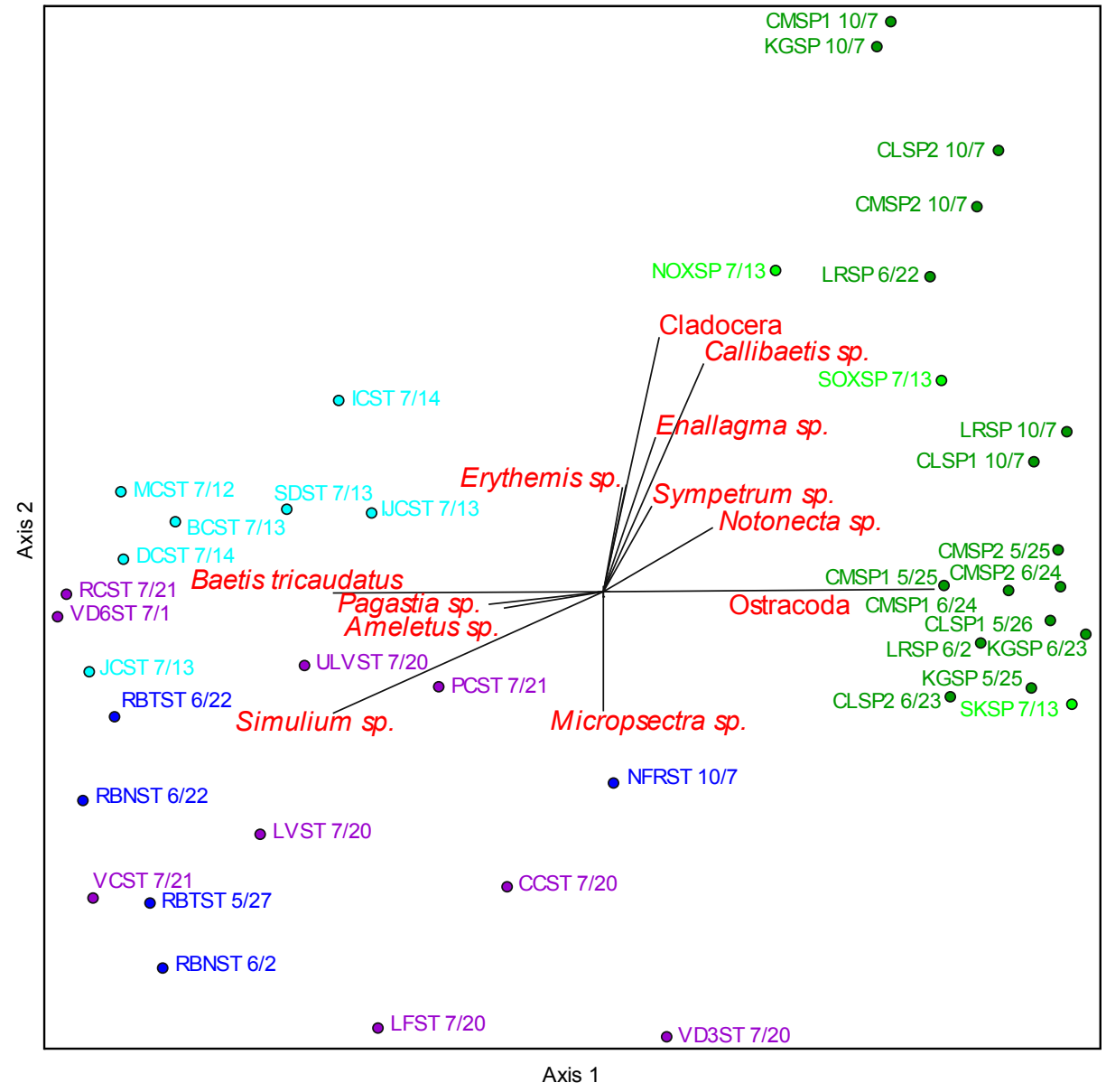

Axis 1 
ecological impact of changes in Lygaeidae numbers, if they are affected by diflubenzuron, is probably relatively minor given the small population of bugs that will be affected.

Scorpions and solifugids are large, nocturnal predators that forage on the ground. Scorpions and solifugids compete for food (Polis and McCormick; 1986a, Polis and others, 1989). Polis and McCormick (1986a) found that scorpions and solifugids also prey on each other. Thus, it is not surprising to find an inverse correlation between scorpion and solifugid abundance. This correlation was seen among the untreated sites at Ibapah. The association is reversed among plots treated with diflubenzuron in 2004. The data indicate that, rather than some interaction between scorpions and solifugids in the presence of diflubenzuron, scorpions may simply be more sensitive to diflubenzuron than solifugids. There was a dramatic decline in scorpion numbers in treated sites compared to untreated sites, while solifugid abundance remained unchanged. In the 4 untreated areas, 34 solifugids were found in traps, and 40 solifugids were caught in the traps in the treated zone. Only 6 scorpions were caught within the treated zone, while 24 scorpions were trapped in the untreated zone.

Scorpion life histories may make them more susceptible to exposure to diflubenzuron. Young scorpions molt more frequently than older individuals (Polis and McCormick, 1986b); if more young individuals are present during treatment periods, the numbers could be affected. Another possibility is that scorpions' prey may have been affected more than the solifugids' prey. Thus, scorpion numbers declined, but solifugid numbers remained relatively unchanged in the treatment zone. At least one group of large, potential prey showed concomitant declines at the treated sites at Ibapah; Orthoptera were roughly one-third as abundant at treated sites as at untreated sites ( 62 total at the 4 treated sites compared to 172 total at the 4 untreated sites, fig. $16 H$ ). The relative importance of Orthoptera in scorpion and solifugid diets should be explored to test this hypothesis.

Scorpions eat solifugids and solifugids eat scorpions. In the Coachella Valley of California, Polis and McCormick (1986a) found the diet of the scorpion Paruroctonus mesaensis consisted of up to 14.4 percent solifugids and up to 65.4 percent intraguild prey (spiders, scorpions, and solifugids). However, in an experiment in which scorpions were removed from experimental plots and the numbers of solifugids and spiders were sampled spring and fall for 2 years, no significant increases in numbers or size of solifugids were observed in the removal plots compared to the control plots where scorpions were not removed (Polis and McCormick, 1986b). In our study, solifugid numbers did not differ in treated and untreated zones despite a fourfold difference in scorpion numbers, which is consistent with the findings of Polis and McCormick (1986b) that indicate solifugids do not show a numerical response to reduction or removal of a potential competitor/ predator.

The importance of scorpions in Great Basin sagebrush communities has not been well studied, but they can be extremely abundant in some systems (Polis and McCormick, 1986a) and may play a significant role in population regulation of other arthropods in arid and semiarid ecosystems. Research is needed to clarify the impact of scorpions on the arthropod community, especially experiments in which scorpions are removed from large plots and other arthropods are monitored.

Numbers of beetles in the families Carabidae and Tenebrionidae were reduced shortly after diflubenzuron treatment (Catangui and others, 2000). Smith and others (2006) reported that tenebrionid beetles (collected in pitfall traps) and Coleoptera (collected with sweep nets) showed some differences in response to a variety of carbaryl and diflubenzuron treatments. Coleoptera collected in sweep nets had the most consistent response to diflubenzuron and carbaryl, with fewer beetles caught in all insecticide applications compared to the control plots. We found significant reductions in beetles at Vernon and markedly fewer beetles at Ibapah, indicating there may be long-term effects on beetles from diflubenzuron application in the Great Basin.

Ants and beetles are major components of sage grouse chick diets, as are many Orthoptera (Klebenow and Gray, 1968; Peterson, 1970; Pyle and Crawford, 1996; Drut and others, 1994). Few food-habit studies of sage grouse chicks have been done, and many lump invertebrates found in bird stomachs into very basic categories (for example, "beetles" or "worms"); thus, it is difficult to assess from these studies the potential effect of changes in arthropod communities from diflubenzuron application on sage grouse population dynamics. Because chicks concentrate on insects and other arthropods during the first month after hatching, even a temporary decline in numbers, such as those reported by Catangui and others (2000), could have a significant impact on sage grouse chick survival. Sample and others (1993) found that five species of songbirds in diflubenzuron-treated sites had significantly different and potentially less nutritious diets compared to songbirds in untreated sites, and two species in treated sites had significantly less invertebrate biomass in their stomachs. Whitmore and others (1993) found seven of nine bird species tested on diflubenzuron-treated plots had lower fat levels than those on untreated plots due to reductions in invertebrate prey populations, increased foraging costs, reduction in food quality, or some combination of the three. Bell and Whitmore (1997) reported lower numbers of birds of most species in plots that had been treated with diflubenzuron, and they attributed this to a reduction in habitat quality related to prey availability in treated forest plots.

Our temporal comparisons, while covering the critical insectivore phase of sage grouse chick life history (Drut and others, 1994), did not yield definitive results because of the extreme variability in sites and taxa response to diflubenzuron and the uncertainty of sage grouse chick food preferences. However, diflubenzuron application to control Orthoptera has the potential to affect sage grouse chick foraging by altering prey-species composition and/or abundance. Survival of chicks has been shown to be critical for sustainable sage grouse populations (Johnson and Boyce, 1990). Additional work is needed to clarify whether diflubenzuron affects sage grouse chick 
survival and, thus, sage grouse population dynamics in areas where Mormon cricket or grasshopper control occurs.

\section{Aquatic Study}

This study provides one of the first quantitative, comprehensive assessments of aquatic invertebrates in these areas of Utah's west desert and, consequently, will provide valuable baseline data for future studies. Within the three study areas, 169 different aquatic taxa were collected, including 17 orders and 59 families. Taxa varied among study areas and between streams and springs. Crustaceans dominated springs, while mayflies (Ephemeroptera) and true flies (Diptera) dominated streams.

Although the pesticide-spraying program was specifically designed with buffers to avoid direct spraying of aquatic habitats, we included sampling of aquatic habitats and identification of aquatic macroinvertebrates as part of this study to confirm that there was no impact on the aquatic systems. In general, our results showed no significant differences in community composition, richness, or abundance between the treated and untreated zones. In some instances, it is possible that differences caused by pesticide spraying were masked by large environmental differences; and in the one case where there was a statistically significant difference between the treated and untreated zone, the results were confounded by elevational differences between the two zones.

Grouse Creek was the only study area treated in 2005. There was no significant difference in abundance or richness between sites inside and outside the treatment zones after treatment, and because water bodies were buffered (no pesticide was sprayed within about $150 \mathrm{~m}$ of a water body), this result is not unexpected. The initial study design called for collection of water samples to be tested for diflubenzuron but this was not possible given the timing of the first, and only, spraying at Grouse Creek. Future studies should collect and analyze water samples to confirm that the buffer zones are indeed areas that are not being sprayed.

Ibapah was sprayed in 2004 but not in 2005 (the year we sampled). Again, there was no significant difference in species abundance or richness between sites inside and outside the treatment zone. Sites outside the treatment zone at Ibapah included three springs and two streams. We were able to locate and sample only streams inside of the treatment zone. This difference in habitat type may mask a pesticide effect on abundance because the three springs (all located outside of the treatment zone) had substantially higher abundance than any of the streams.

All sampling sites at Vernon were classified as streams for this study. However, some sites were actual streams (which were buffered from spraying) and some were ditches (which were not buffered). There was no significant difference in abundance between sites inside and outside the treatment zone, even considering ditches versus streams. However, taxa richness was significantly higher in the untreated zone than the treated zone and higher in the actual streams than in the ditches. This finding may indicate an impact of pesticide spraying, but the difference in elevation confounds this interpretation. Sites at the lower elevations (treated zone) tended to be irrigation ditches, and sites at the higher elevations (untreated zone) were relatively pristine streams. This elevation gradient also represents a gradient in habitat quality, which would have an influence on community composition. The significant differences observed between treated and untreated sites at Vernon may be due to the inherent variation among the sites rather than from diflubenzuron. Nevertheless, it is possible that pesticide treatment contributed to the observed significant differences. Future studies designed to separate environmental differences between sites and treatment effects could provide a clearer assessment of the effects of diflubenzuron on aquatic communities in these areas.

Temporal phenology (change during the season) in aquatic communities also confounded our ability to detect the effects of diflubenzuron. Grouse Creek, the only study area treated in 2005, was sampled three times during this study. We sampled before treatment, 2 weeks after treatment, and 4 months after treatment. Generally, abundance and richness increased from pre-treatment samples to 2-week posttreatment samples, and decreased from 2-week post-treatment samples to 3-month post-treatment samples. Changes in abundance and richness are most likely due to natural temporal variation, whereby aquatic-invertebrate populations peak in June, and their populations decrease again with colder weather in October. Consequently, evaluation of any effects of diflubenzuron application is confounded by temporal phenology in aquatic communities. Future studies will be able to use baseline data collected during this study to separate changes in community composition associated with temporal phenology from those associated with diflubenzuron.

\section{Conclusions}

Our study design included several treated and untreated zones to facilitate statistical comparisons. Because a limited outbreak of Orthoptera occurred in 2005, only one area was treated with diflubenzuron, thus, severely limiting our ability to detect the effects of the pesticide spraying.

The effects of diflubenzuron on aquatic and terrestrial arthropod communities are not apparent in our data from Grouse Creek, the only area treated in 2005. The treatment was designed to avoid spraying pesticide on water bodies, and no measurable impacts on aquatic community composition, richness, or abundance on either springs or streams were observed, with the exception of reduced taxa richness at Vernon (a result confounded by elevational differences in the treatment and nontreatment zones). Our study did indicate that treatment with diflubenzuron was correlated with changes in abundance for some terrestrial taxa, notably some ant genera, the Lygaeidae (Hemiptera), non-ant Hymenoptera, beetles (Coleoptera), and scorpions (Scorpiones). 
Important ecosystem functions (for example, seed predation and pollination) are performed by the arthropods showing reduced abundance during this study, and, thus, ecological function could be adversely affected by declines caused by diflubenzuron application. Many of these taxa are used by sage grouse chicks at a critical stage in their development; sustainability of sage grouse populations could be indirectly affected by use of diflubenzuron in sage grouse brood habitat. Differences between sprayed and unsprayed zones were greater at Ibapah and Vernon when sampled a year after diflubenzuron application, suggesting that the effect may lag behind application. Although direct effects may still occur, the potential for indirect effects increases greatly. Differences in abundance may not be observed at higher taxonomic levels (for example, order or family) for some taxa; thus, work to evaluate the effects of diflubenzuron on nontarget arthropods should include identification of arthropods to at least family, and for ecologically or taxonomically diverse groups (for example, ants), identification should be to genus and species when possible.

Although few apparent short-term effects of diflubenzuron on terrestrial arthropods at Grouse Creek were observed that were statistically significant, mean abundances of some taxa at Ibapah and Vernon were significantly different at untreated sites than at sites treated with diflubenzuron the previous year, and nearly significant differences were observed at all three study areas. The same taxa differed over several study areas. Sometimes the differences were statistically significant and sometimes they were not. These taxa, which included Coleoptera, Diptera, Hemiptera, non-ant Hymenoptera, Lepidoptera, Orthoptera, and Scorpiones, may be more susceptible to diflubenzuron. Additional research targeting these taxa would be informative. Funding should be sought to identify specimens of the taxa collected in this study to the lowest taxonomic level possible (at least to genus, preferably to species). This finer resolution may show which taxa are actually affected by pesticide spraying. For example, the mean number of ants (as a group) did not differ for any comparison of the treated and untreated zones, but there were significant differences for some genera. The same could be true for Coleoptera, Diptera, or other taxa.

In the aquatic community analyses, species composition, richness, and abundance were highly variable among sites. This high variability, combined with the fact that only one pesticide treatment had occurred in only one area, made it difficult to assess treatment effects. Replicate sampling within sites or an increase in the number of sampled sites could reduce this variability. Because it may be difficult to add more sites (we sampled at all of the water bodies we could find), additional habitat characterization could allow for better comparisons among similar groups of sites.

To determine whether diflubenzuron application caused the observed differences in either terrestrial or aquatic arthropod communities, a study should be designed to control for environmental differences. Ideally, an area where Mormon cricket-control is judged to be needed should be divided into randomly assigned treatment and nontreatment blocks and sampled extensively the year prior to treatment to provide quantitative baseline data. Sampling should also occur just before treatment and at several intervals after treatment from about 3 weeks to at least 18 months.

Control efforts will continue to affect nontarget arthropods as long as diflubenzuron is the insecticide of choice; the current application methods are likely the most effective for Orthoptera control and do not lend themselves to avoiding particular patches in the treated areas. Although additional research is needed to clarify the suspected relationships identified in this study, we recognize that efforts to control Orthoptera on rangelands in the Intermountain West will continue. We suggest that the potential impacts of diflubenzuron treatment discussed here be considered in future decisions regarding control efforts. The value of Orthopteran population control must be weighed against the potential direct and indirect effects on ecosystem structure and functioning that may result from changes in arthropod community structure through shifts in sensitive taxa.

\section{Acknowledgments}

We would like to thank Mike Freeman, Annie Caires, Patrick Milliman, Tyler Cuff, James Hereford, Lisa Bryant, and Lovina Abbott for their help in digging pitfall traps, collecting trap contents, and collecting aquatic samples. Evelyn Cheng, Julius Schoen, Jessie Doherty, Kristen Shelburg, Rebecca Allmond, April Johnson, John Barry, and Steve Deakins sorted and identified terrestrial arthropod samples. Sandy Brantley identified some spiders to start a reference collection; Jack Brookhart identified the Solifugae. Aquatic samples were identified and enumerated by Rhithron in Missoula, Montana. Gery Wakefield and Karen Hansen provided GIS support, including generating random points and making many maps. Paul Lukacs generated the pitfall trap layout in WebSim. Project design benefited from discussions with Greg Abbott, Lisa Bryant, Clint Burfitt, and comments from two reviewers of the proposal. Funding for fieldwork was provided by the Bureau of Land Management. Funding to process samples, identify specimens, and analyze data was provided by the Utah Department of Agriculture and Food, and the U.S. Geological Survey Southwest Biological and Utah Water Science Centers.

\section{References}

Andersen, A.N., Hoffmann, B.D., Mueller, W.J., and Griffiths, A.D., 2002, Using ants as bioindicators in land management-Simplifying assessment of ant community responses: Journal of Applied Ecology, v. 39, no. 1, p. 8-17. 
Andersen, A.N., and Majer, J.D., 2004, Ants show the way down under-Invertebrates as bioindicators in land management: Frontiers in Ecology and Environment, v. 2, no. 6, p. 291-298

Bell, J.L., and Whitmore, R.C., 1997, Bird populations and habitat in Bacillus thuringiensis and dimilin-treated and untreated areas of hardwood forest: American Midland Naturalist, no. 137, p. 239-250.

Bestelmeyer, B.T., and Wiens, J.A., 1996, The effects of land use on the structure of ground-foraging ant communities in the Argentine Chaco: Ecological Applications, v. 6, no. 4, p. $1225-1240$.

Buckland, S.T., Anderson, D.R., Burnham, K.P., Laake, J.L., Borchers, D.L., and Thomas, L., eds., 2001, Introduction to distance sampling-Estimating abundance of biological populations: Oxford, United Kingdom, Oxford University Press, 423 p.

Buckley, R., 1987, Ant-plant-homopteran interactions: Advances in Ecological Research, v. 16, p. 53-85.

Catangui, M.A., Fuller, B.W., and Walz, A.W., 2000, VII.3 Impact of Dimilin ${ }^{\circledR}$ on nontarget arthropods and its efficacy against rangeland grasshoppers, in Cunningham, G.L., and Sampson, M.W., eds., Grasshopper Integrated Pest Management User Handbook: Washington, D.C., U.S. Department of Agriculture, Animal and Plant Health Inspection Service, p. 1-5.

Cuffney, T.F., 2003, User's manual for the national water-quality assessment program invertebrate data analysis system (IDAS) software-Version 3: U.S. Geological Survey OpenFile Report 03-172, 103 p.

Drut, M.S., Pyle, W.H., and Crawford, J.A., 1994, Diets and food selection of sage grouse chicks in Oregon: Journal of Range Management, v. 47, p. 90-93.

Fischer, M.K., and Shingleton, A.W., 2001, Host plant and ants influence the honeydew sugar composition of aphids: Functional Ecology, v. 15, no. 4, p. 544-550.

Greenslade, P.J.M., 1976, The meat ant Iridomyrmex purpureus (Hymenoptera: Formicidae) as a dominant member of ant communities: Australian Journal of Entomology, v. 15, no. 2, p. 237-240.

Johnson, G.D., and Boyce, M.S., 1990, Feeding trials with insects in the diet of sage grouse chicks: Journal of Wildlife Management, v. 54, p. 89-91.

Klebenow, D.A., and Gray, D.M., 1968, Food habits of juvenile sage grouse: Journal of Range Management, v. 21, p. 80-83.
Lobry de Bruyn, L.A., and Conacher, A.J., 1990, The role of termites and ants in soil modification-a review: Australian Journal of Soil Research, v. 28, p. 55-93.

Lobry de Bruyn, L.A., and Conacher, A.J., 1994, The bioturbation activity of ants in agricultural and naturally vegetated habitats in semi-arid environments: Australian Journal of Soil Research, v. 32, p. 555-570.

Lukacs, P.M., 2001, Estimating density of animal populations using trapping webs-Evaluation of web design and data analysis: Fort Collins, Colo., Colorado State University, 90 p.

Lukacs, P.M., 2002, WebSim-Simulation software to assist in trapping web design: Wildlife Society Bulletin, v. 30, p. 1259-1261.

Lukacs, P.M., Franklin, A.B., and Anderson, D.R., 2004, Passive approaches to detection in distance sampling, in Buckland, S.T., and others, eds., Advanced distance samplingEstimating abundance of biological populations: Oxford, United Kingdon, Oxford University Press, p. 260-280.

McCune, B., and Grace, J.B., 2002, Analysis of ecological communities: Gleneden Beach, Oreg., MjM Software, 304 p.

McCune, B., and Mefford, M.J., 2005, PC-ORD, Multivariate analysis of ecological data, Version 5.0 (5th ed.): Gleneden Beach, Oreg., MjM Software Design, p. 237.

McEwen, L.C., Althouse, C.M., and Peterson, B.E., 1996, Direct and indirect effects of grasshopper integrated pest management (GHIPM) chemicals and biologicals on nontarget animal life: U.S. Department of Agriculture, Animal and Plant Health Inspection Service Technical Bulletin 1809, Section III.2.

Nash, M.S., Bradford, D.F., Franson, S.E., Neale, A.C., Whitford, W.G., and Heggem, D.T., 2004, Livestock grazing effects on ant communities in the eastern Mojave Desert, USA: Ecological Indicators, v. 4, no. 3, p. 199-213.

Nash, M.S., Whitford, W.G., Bradford, D.F., Franson, S.E., Neale, A.C., and Heggem, D.T., 2001, Ant communities and livestock grazing in the Great Basin, U.S.A: Journal of Arid Environments, v. 49, no. 4, p. 695-710.

Nash, M.S., Whitford, W.G., Van, Z.J., and Havstad, Kris, 1998, Monitoring changes in stressed ecosystems using spatial patterns of ant communities: Environmental Monitoring and Assessment, v. 51, no. 1-2, p. 201-210.

New, T.R., 1998, Invertebrate surveys for conservation: Oxford, United Kingdom, Oxford University Press, 240 p. 
Offenberg, Joachim, 2001, Balancing between mutualism and exploitation: the symbiotic interaction between Lasius ants and aphids: Behavioral Ecology and Sociobiology, v. 49, no. 4, p. 304-310.

Peterson, J.G., 1970, The food habits and summer distribution of juvenile sage grouse in central Montana: Journal of Wildlife Management, v. 34, p. 147-155.

Polis, G.A., and McCormick, S.J., 1986a, Scorpions, spiders, and solpugids-Predation and competition among distantly related taxa: Oecologia, v. 71, no. 1, p. 111-116.

Polis, G.A., and McCormick, S.J., 1986b, Patterns of resource use and age structure among species of desert scorpion: Journal of Animal Ecology, v. 55, no. 1, p. 59-73.

Polis, G.A., Myers, C.A., and Holt, R., 1989, The ecology and evolution of intraguild predation-Potential competitors that eat each other: Annual Review of Ecology and Systematics, v. 20, p. 297-330.

Prior-Magee, J.S., Boykin, K.G., Bradford, D.F., Kepner, W.G., Lowry, J.H., Schrupp, D.L., Thomas, K.A., and Thompson, B.C., eds., 2007, Southwest Regional Gap Analysis Project final report: Moscow, Idaho, U.S. Geological Survey.

Pyle, W. H. and J. A. Crawford (1996). Availability of foods of sage grouse chicks following prescribed fire in sagebrush-bitterbrush: Journal of Range Management, v.49, p. 320-324.

Read, J.L., and Andersen, A.N., 2000, The value of ants as early warning bioindicators-Responses to pulsed cattle grazing at an Australian arid zone locality: Journal of Arid Environments, v. 45, no. 3, p. 231-251.

Readio, J., and Sweet, M.H., 1982, A review of the Geocorinae of the United States east of the 100th meridian (Hemiptera: Lygaeidae): Miscellaneous Publications of the Entomological Society of America, v. 12, p. 1-91.

Risch, S.J., and Carroll, C.R., 1982, The ecological role of ants in two Mexican agroecosystems: Oecologia, v. 55, p. 114-119.

S-PLUS, 2000: Seattle, MathSoft, Inc.

Sample, B.E., Cooper, R.J., and Whitmore, R.C., 1993, Dietary shifts among songbirds from a diflubenzurontreated forest: The Condor, v. 95, p. 616-624.

Schuh, R.T., and Slater, J.A., 1995, True bugs of the world (Hemiptera: Heteroptera)_Classification and natural history: New York, Cornell University Press, 336 p.
Smith, D.I., Lockwood, J.A., Latchininsky, A.V., and Legg, D.E., 2006, Changes in non-target arthropod populations following application of liquid bait formulations of insecticides for control of rangeland grasshoppers: International Journal of Pest Management, v. 52, p. 125-139.

Systat, 2004, SigmaStat: Richmond, Calif., Systat Software, Inc.

Triplehorn, C.A., and Johnson, N.F., 2005, Borror and DeLong's introduction to the study of insects, 7th ed.: Belmont, Calif., Thomson Brooks/Cole, 864 p.

U.S. Department of Agriculture, 2002, Rangeland grasshopper and Mormon cricket suppression program: Animal and Plant Health Inspection Service, U.S. Dept. of Agriculture, $88 \mathrm{p}$.

Weiland, R.T., Judge, F.D., Pels, Teun, and Grosscurt, A.C., 2002, A literature review and new observations on the use of diflubenzuron for control of locusts and grasshoppers throughout the world: Journal of Orthoptera Research, v. 11, no. 1 , p. 43-54.

Whitford, W.G., Van Zee, J., Nash, M.S., Smith, W.E., and Herrick, J.E., 1999, Ants as indicators of exposure to environmental stressors in North American desert grasslands: Environmental Monitoring and Assessment, v. 54, no. 2, p. $143-171$.

Whitmore, R.C., Cooper, R.J., and Sample, B.E., 1993, Bird fat reductions in forests treated with dimilin: Environmental Toxicology and Chemistry, v. 12, p. 2059-2064.

Wilcox, H., III, and Coffey, T., Jr., 1978, Environmental impacts of diflubenzuron (Dimilin) insecticide: U.S. Department of Agriculture, Forest Service, 18 p. 


\section{Appendix A: Terrestrial Taxa Collected-Total Number of Arthropods Caught During Each Sampling Event at Each Site}

Table A1a. Number of arthropods, by order, captured at each site in the untreated area at Grouse Creek, before and after treatment.

\begin{tabular}{|c|c|c|c|c|c|c|c|c|}
\hline & $\begin{array}{l}\text { GC U01 } \\
\text { pre- } \\
\text { treatment }\end{array}$ & $\begin{array}{l}\text { GC U01 } \\
\text { post- } \\
\text { treatment }\end{array}$ & $\begin{array}{l}\text { GC U05 } \\
\text { pre- } \\
\text { treatment }\end{array}$ & $\begin{array}{l}\text { GC U05 } \\
\text { post- } \\
\text { treatment }\end{array}$ & $\begin{array}{l}\text { GC U06 } \\
\text { pre- } \\
\text { treatment }\end{array}$ & $\begin{array}{l}\text { GC U06 } \\
\text { post- } \\
\text { treatment }\end{array}$ & $\begin{array}{l}\text { GC U11 } \\
\text { pre- } \\
\text { treatment }\end{array}$ & $\begin{array}{l}\text { GC U11 } \\
\text { post- } \\
\text { treatment }\end{array}$ \\
\hline Coleoptera & 162 & 516 & 181 & 355 & 84 & 333 & 29 & 76 \\
\hline Diptera & 400 & 1,220 & 626 & 240 & 352 & 303 & 457 & 549 \\
\hline Hemiptera & 233 & 8,581 & 404 & 34,856 & 262 & 1,420 & 88 & 410 \\
\hline Formicidae & 173 & 453 & 151 & 150 & 602 & 786 & 456 & 869 \\
\hline non-ant Hymenoptera & 115 & 669 & 123 & 240 & 70 & 197 & 44 & 200 \\
\hline Lepidoptera & 64 & 33 & 114 & 37 & 12 & 25 & 23 & 95 \\
\hline \multicolumn{9}{|l|}{ Mantodea } \\
\hline Neuroptera & 13 & & & 1 & & & 1 & 5 \\
\hline Orthoptera & 1 & 18 & 12 & 20 & 34 & 73 & 36 & 381 \\
\hline Microcoryphia & 6 & 3 & & & & 1 & & 19 \\
\hline Trichoptera & 1 & 1 & & & & & & 1 \\
\hline Araneae & 61 & 139 & 85 & 144 & 86 & 205 & 88 & 325 \\
\hline Scorpiones & 2 & 16 & & & 6 & 14 & & 13 \\
\hline \multicolumn{9}{|l|}{ Solifugae } \\
\hline \multicolumn{9}{|l|}{ Pseudoscorpiones } \\
\hline Chilopoda & & 1 & & & & & 2 & 2 \\
\hline \multicolumn{9}{|l|}{ Diplopoda } \\
\hline Total arthropods & 1,231 & 11,650 & 1,696 & 36,043 & 1,508 & 3,357 & 1,224 & 2,945 \\
\hline
\end{tabular}




\section{Mormon Cricket Control in Utah's West Desert—Evaluation of Impacts of the Pesticide Diflubenzuron}

Table A1b. Number of arthropods, by order, captured at each site in the treated area at Grouse Creek, before and after treatment.

\begin{tabular}{|c|c|c|c|c|c|c|c|c|}
\hline & $\begin{array}{c}\text { GC T03 pre- } \\
\text { treatment }\end{array}$ & $\begin{array}{c}\text { GC T03 post- } \\
\text { treatment }\end{array}$ & $\begin{array}{l}\text { GC T04 pre- } \\
\text { treatment }\end{array}$ & $\begin{array}{c}\text { GC T04 post- } \\
\text { treatment }\end{array}$ & $\begin{array}{c}\text { GC T05 pre- } \\
\text { treatment }\end{array}$ & $\begin{array}{c}\text { GC T05 post- } \\
\text { treatment }\end{array}$ & $\begin{array}{c}\text { GC T06 pre- } \\
\text { treatment }\end{array}$ & $\begin{array}{c}\text { GC T06 post- } \\
\text { treatment }\end{array}$ \\
\hline Coleoptera & 25 & 80 & 93 & 114 & 88 & 65 & 34 & 100 \\
\hline Diptera & 230 & 161 & 314 & 747 & 858 & 204 & 83 & 223 \\
\hline Hemiptera & 671 & 1,268 & 295 & 2,264 & 676 & 914 & 407 & 1,401 \\
\hline Formicidae & 276 & 351 & 381 & 597 & 407 & 408 & 134 & 334 \\
\hline non-ant Hymenoptera & 21 & 76 & 42 & 121 & 33 & 52 & 48 & 103 \\
\hline Lepidoptera & 23 & 16 & & 53 & & 7 & 18 & 43 \\
\hline Mantodea & 1 & 1 & & & & & & 1 \\
\hline Neuroptera & 1 & 3 & 1 & 3 & & & 9 & 6 \\
\hline Orthoptera & 48 & 57 & 133 & 22 & 79 & 27 & 42 & 53 \\
\hline Microcoryphia & 1 & & & & & & & 12 \\
\hline Trichoptera & 1 & & & 1 & & & 2 & \\
\hline Araneae & 56 & 73 & 36 & 120 & 118 & 91 & 76 & 206 \\
\hline Scorpiones & 2 & 2 & & 4 & 2 & 6 & & 1 \\
\hline Solifugae & & & & & & 1 & & \\
\hline Pseudoscorpiones & & & & & & & & 1 \\
\hline Chilopoda & 1 & & & 2 & & 1 & & 1 \\
\hline \multicolumn{9}{|l|}{ Diplopoda } \\
\hline Total arthropods & 1,357 & 2,088 & 1,295 & 4,048 & 2,261 & 1,776 & 853 & 2,485 \\
\hline
\end{tabular}

Table A1c. Number of arthropods, by order, captured at each site in Ibapah.

\begin{tabular}{|c|c|c|c|c|c|c|c|c|}
\hline & $\begin{array}{c}\text { IB U03 } \\
\text { untreated }\end{array}$ & $\begin{array}{c}\text { IB U06 } \\
\text { untreated }\end{array}$ & $\begin{array}{c}\text { IB U08 } \\
\text { untreated }\end{array}$ & $\begin{array}{c}\text { IB U09 } \\
\text { untreated }\end{array}$ & $\begin{array}{l}\text { IB T13 } \\
\text { treated }\end{array}$ & $\begin{array}{l}\text { IB T19 } \\
\text { treated }\end{array}$ & $\begin{array}{l}\text { IB T21 } \\
\text { treated }\end{array}$ & $\begin{array}{l}\text { IB T22 } \\
\text { treated }\end{array}$ \\
\hline Coleoptera & 52 & 62 & 64 & 31 & 33 & 50 & 31 & 26 \\
\hline Diptera & 155 & 246 & 206 & 96 & 130 & 90 & 128 & 125 \\
\hline Hemiptera & 632 & 428 & 10,289 & 429 & 2,287 & 414 & 638 & 298 \\
\hline Formicidae & 525 & 868 & 452 & 825 & 631 & 823 & 841 & 773 \\
\hline non-ant Hymenoptera & 28 & 46 & 27 & 58 & 67 & 54 & 61 & 100 \\
\hline Lepidoptera & 39 & 37 & 13 & 35 & 16 & 17 & 20 & 25 \\
\hline Mantodea & 1 & 1 & & & 1 & & 2 & \\
\hline Neuroptera & 4 & & & & & & 1 & \\
\hline Orthoptera & 40 & 42 & 22 & 68 & 29 & 9 & 7 & 17 \\
\hline Microcoryphia & & & & & & & & 219 \\
\hline \multicolumn{9}{|l|}{ Trichoptera } \\
\hline Araneae & 72 & 177 & 76 & 66 & 148 & 148 & 95 & 143 \\
\hline Scorpiones & 3 & 4 & 9 & 8 & 3 & 1 & 2 & \\
\hline Solifugae & 19 & 11 & 1 & 3 & 12 & 8 & 15 & 5 \\
\hline Pseudoscorpiones & 1 & 2 & & 3 & & 2 & & \\
\hline \multicolumn{9}{|l|}{ Chilopoda } \\
\hline \multicolumn{9}{|l|}{ Diplopoda } \\
\hline Total arthropods & 1,571 & 1,924 & 11,159 & 1,622 & 3,357 & 1,616 & 1,841 & 1,731 \\
\hline
\end{tabular}


Table A1d. Number of arthropods, by order, captured at each site in Vernon.

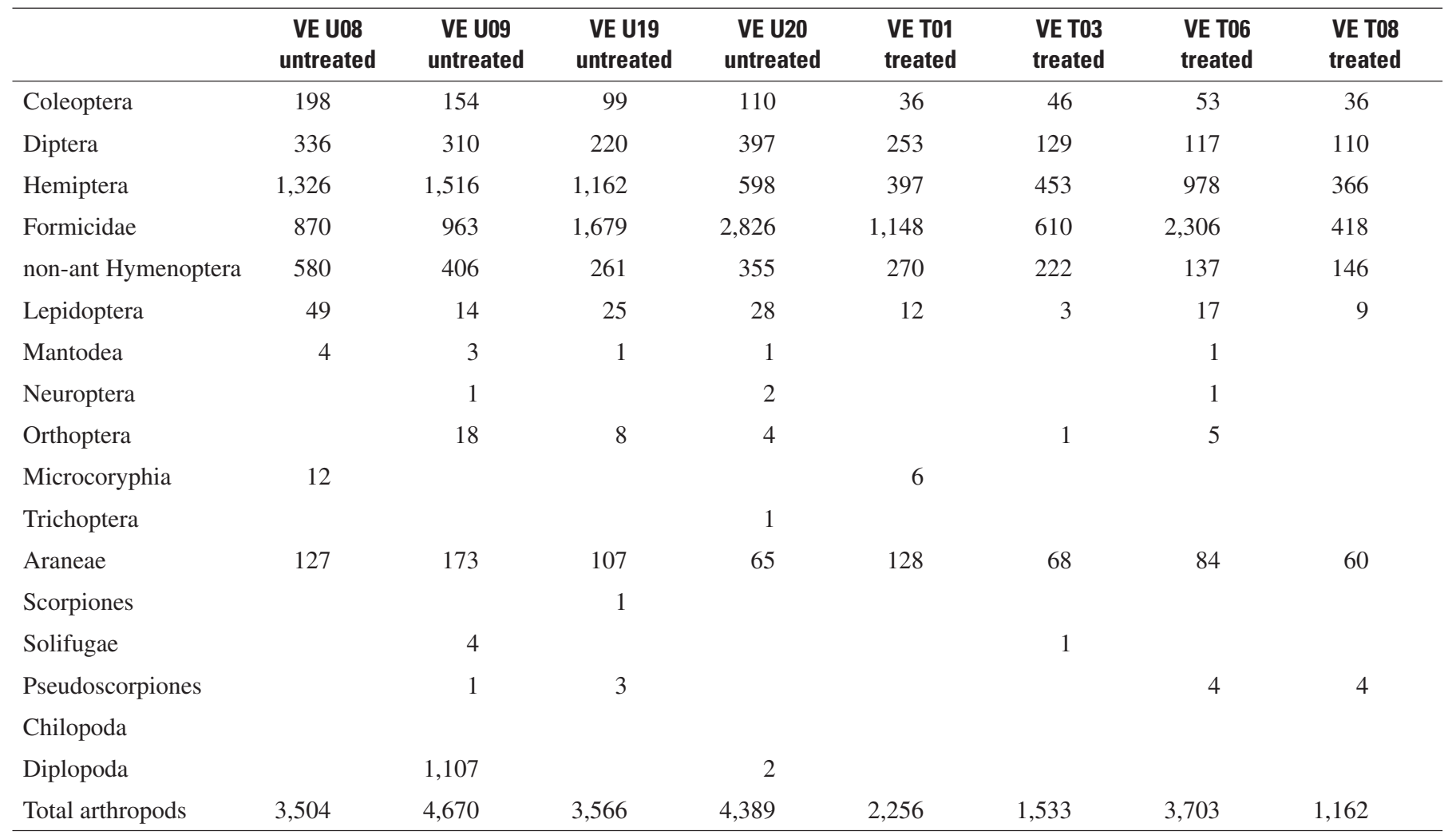


Table A2. Total numbers of ants by genus collected in pitfall traps at each site and sampling event in the three study areas.

\begin{tabular}{|c|c|c|c|c|c|c|c|c|c|c|c|c|c|c|c|c|c|c|c|}
\hline Ants & 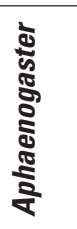 & 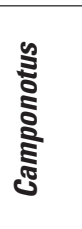 & 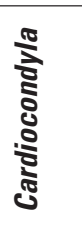 & 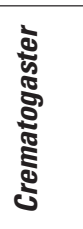 & 离 & : & 胥 & 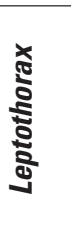 & 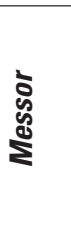 & 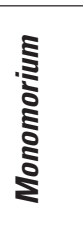 & 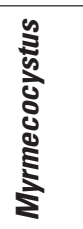 & : & $\frac{\stackrel{0}{\frac{2}{2}}}{\frac{0}{2}}$ & 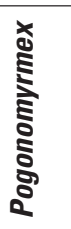 & $\frac{\mathfrak{s}}{\stackrel{5}{0}}$ & 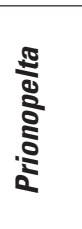 & $\begin{array}{l}\frac{\infty}{\omega} \\
\frac{0}{0} \\
\frac{0}{0} \\
\dot{0}\end{array}$ & 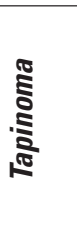 & $\frac{\infty}{\mathbb{\pi}}$ \\
\hline GC U01pre & & & & & & 72 & & & & & & & & 91 & & & 6 & 3 & 172 \\
\hline GC U05pre & & & & & & 138 & & 6 & & & & & & 1 & & & & 5 & 150 \\
\hline GC U06pre & & & & & & 200 & 123 & 165 & 1 & & 8 & & & 93 & & & 2 & & 592 \\
\hline GC U11pre & 19 & 6 & & & 20 & 285 & & 47 & & & & 2 & 36 & 25 & & & 16 & & 456 \\
\hline GC T03pre & & & 1 & 18 & 164 & 1 & & 18 & & & 1 & & 41 & 3 & & & 28 & & 275 \\
\hline GC T04pre & 3 & 16 & & & & 139 & 53 & 88 & & & 7 & 17 & & 51 & 4 & & 1 & & 379 \\
\hline GC T05pre & 4 & 5 & & & & 47 & 56 & 78 & & & 5 & & 67 & 21 & & & 119 & 2 & 404 \\
\hline GC T06pre & & 5 & & & 2 & 88 & 1 & 34 & & & & 1 & & & & & 2 & & 133 \\
\hline GC U01post & & & & & & 155 & & 1 & & & & & & 270 & & & 25 & 1 & 452 \\
\hline GC U05post & & & & & & 118 & & 17 & & & & & & 10 & & 1 & 1 & 2 & 149 \\
\hline GC U06post & & & & & & 380 & 88 & 77 & & & 12 & 6 & 10 & 182 & 2 & & 27 & & 784 \\
\hline GC U11post & 18 & 64 & & & 127 & 310 & & 102 & & & 1 & 1 & 112 & 73 & & 2 & 56 & & 866 \\
\hline GC T03post & 1 & & & 42 & 101 & 1 & & 24 & 1 & & 2 & & 120 & 7 & & & 51 & & 350 \\
\hline GC T04post & & 19 & & & & 189 & 69 & 120 & & & 1 & 11 & & 169 & 1 & & 10 & 1 & 590 \\
\hline GC T05post & 6 & 12 & & & & 37 & 55 & 25 & & & 5 & & 118 & 118 & & & 28 & 4 & 408 \\
\hline GC T06post & & 16 & & & & 215 & & 82 & & & 3 & 13 & & 6 & & & 6 & & 341 \\
\hline IB U03 & & 27 & & & 1 & 34 & & 107 & & & & & 15 & & & & 33 & 44 & 261 \\
\hline IB U06 & & & & & & 279 & 2 & 44 & & & 1 & 81 & & 1 & & & 2 & 448 & 858 \\
\hline IB U08 & & 2 & & & 2 & 212 & & 44 & & & & 11 & & 18 & & & 8 & 43 & 340 \\
\hline IB U09 & & 2 & & & 541 & 11 & & 78 & & & & & 42 & & & & 1 & 112 & 787 \\
\hline IB T13 & & 57 & & & 250 & 71 & & 37 & & & & 50 & 117 & & & & 7 & 20 & 609 \\
\hline IB T19 & & 1 & & 42 & 527 & 24 & & 14 & & & & 25 & 112 & 7 & 1 & & 10 & 1 & 764 \\
\hline IB T21 & & 46 & & & 322 & 12 & 2 & 16 & & & & 28 & 3 & 95 & & & 20 & 3 & 547 \\
\hline IB T22 & 56 & 7 & 5 & 108 & 297 & 51 & & 34 & & & & & 25 & 154 & 1 & & 5 & & 743 \\
\hline VE U08 & 5 & 9 & & & & 48 & 15 & 81 & & 144 & & 37 & 169 & & & & 105 & 253 & 866 \\
\hline VE U09 & 37 & 78 & & & & 315 & & 121 & & 196 & & & 141 & & & & 45 & 29 & 962 \\
\hline VE U19 & & 25 & & & & 125 & 57 & 22 & & 592 & 1 & 460 & 4 & 29 & & & 42 & 315 & 1,672 \\
\hline
\end{tabular}


Table A2. Total numbers of ants by genus collected in pitfall traps at each site and sampling event in the three study areas-Continued.

\begin{tabular}{|c|c|c|c|c|c|c|c|c|c|c|c|c|c|c|c|c|c|c|c|}
\hline Ants & 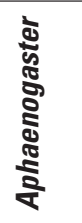 & 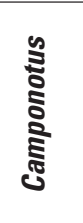 & 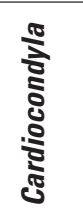 & 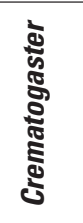 & 㐫 & : & 竎 & 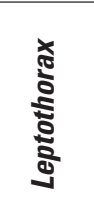 & 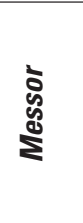 & 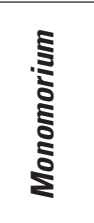 & 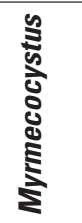 & : & 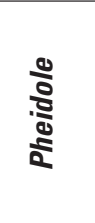 & 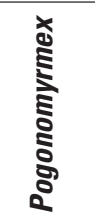 & $\begin{array}{l}\text { ș } \\
\frac{5}{2}\end{array}$ & 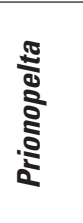 & 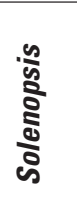 & 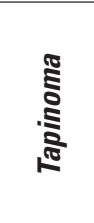 & $\frac{\infty}{\tilde{J}}$ \\
\hline VE U20 & 80 & 26 & & & 1 & 2,212 & 8 & 357 & & 123 & & & & & & & 6 & & 2,813 \\
\hline VE T01 & 39 & 5 & & & 448 & 345 & & 22 & & 108 & & & 137 & 14 & & & 22 & & 1,140 \\
\hline VE T03 & & 2 & & & 66 & & & 86 & & 386 & & 21 & 12 & & & & 32 & & 605 \\
\hline VE T06 & 26 & 5 & & & 1,723 & & & 13 & & 344 & & & 87 & & & & 46 & & 2,244 \\
\hline VE T08 & & 20 & & & 2 & 51 & & 60 & & 205 & & 8 & 61 & & & & 2 & & 409 \\
\hline Totals & 294 & 455 & 6 & 210 & 4,594 & 6,165 & 529 & 2,020 & 2 & 2,098 & 47 & 772 & 1,429 & 1,438 & 9 & 3 & 764 & 1,286 & 22,121 \\
\hline
\end{tabular}


Table A3. Total numbers of Hemiptera by family collected in pitfall traps at each site and sampling event in the three study areas.

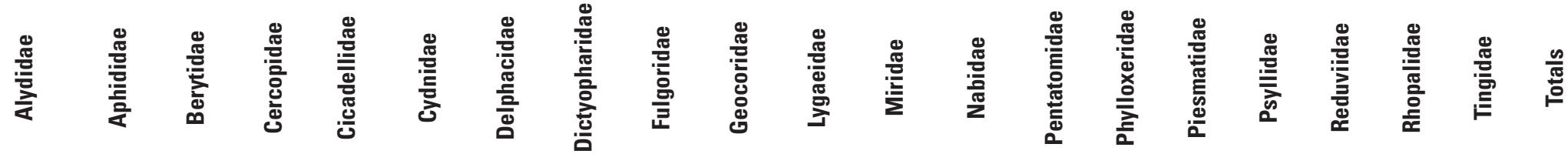

\begin{tabular}{|c|c|c|c|c|c|c|c|c|c|c|c|c|c|c|c|c|c|c|c|}
\hline GC U01pre & & 16 & & & 192 & & & & & & 29 & & & & & & & & 237 \\
\hline GC U05pre & 83 & 2 & & 2 & 126 & & & & & & 174 & 1 & & & & 1 & & 2 & 391 \\
\hline GC U06pre & 4 & 5 & & & 152 & & 4 & & & & 17 & & & & & 1 & & & 183 \\
\hline GC U11pre & & 35 & & & 77 & & 7 & & 2 & & & 2 & & & & & & & 123 \\
\hline GC U01post & 4,485 & 53 & & 28 & 767 & & 3 & 13 & & 19 & 2,470 & 1 & 1 & & & 11 & & 1 & 7,852 \\
\hline GC U05post & 35,852 & 40 & & 3 & 2,349 & & & & & 1 & 450 & 15 & & & 1 & & & & 38,711 \\
\hline GC U06post & 3 & 9 & & 1 & 749 & & 1 & & & 2 & 66 & 1 & 1 & & & 1 & & & 834 \\
\hline GC T04pre & & 59 & & & 462 & & 28 & & & & & & & & & 3 & & & 552 \\
\hline GC T05pre & & 13 & & & 610 & 3 & 25 & & & & 4 & & & & & 5 & & & 660 \\
\hline GC T06pre & & 45 & & & 515 & & 22 & & & & 24 & 2 & & 4 & & 9 & & & 621 \\
\hline GC T03post & & 25 & & 3 & 1,149 & & 9 & & 1 & & 40 & 5 & & & & & & & 1,232 \\
\hline GC T04post & 3 & 65 & & 4 & 1,143 & & 9 & & & & 27 & 4 & & & & 15 & & & 1,270 \\
\hline IB U08 & 3,958 & & & & 612 & & 1 & & & 5 & & 5 & & & & & 1 & & 4,582 \\
\hline IB U09 & 29 & & & & 391 & & 10 & & & 2 & 6 & 5 & & & & & & & 443 \\
\hline IB T13 & 2,006 & & & 8 & 245 & & 16 & & & & 5 & 6 & 1 & & & & & & 2,287 \\
\hline IB T19 & 11 & & & 27 & 372 & & 1 & & & & 1 & 1 & & & & & & & 413 \\
\hline IB T21 & 7 & & & 4 & 614 & & 3 & & & 1 & 2 & 1 & & & & & & & 632 \\
\hline IB T22 & 20 & & & 21 & 240 & & 2 & & & 1 & 8 & 4 & & & & & & & 296 \\
\hline VE U08 & 29 & 3 & & 21 & 971 & & & & 3 & 23 & 21 & 33 & & & & & & & 1,104 \\
\hline VE U09 & & 50 & & 6 & 1,458 & & & & & & & & & & & 2 & & & 1,516 \\
\hline VE U19 & 69 & & & & 14 & & & & 55 & 55 & 221 & 689 & & & & & & & 1,103 \\
\hline
\end{tabular}


Table A3. Total numbers of Hemiptera by family collected in pitfall traps at each site and sampling event in the three study areas-Continued.

\begin{tabular}{|c|c|c|c|c|c|c|c|c|c|c|c|c|c|c|c|c|c|c|c|c|c|c|c|c|}
\hline & $\begin{array}{l}\frac{0}{0} \\
\frac{0}{0} \\
\frac{D}{2}\end{array}$ & $\begin{array}{l}\frac{0}{0} \\
\frac{\pi}{0} \\
\frac{0}{2} \\
\frac{2}{2}\end{array}$ & 总 & & 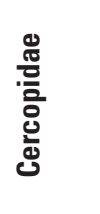 & 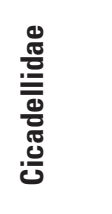 & 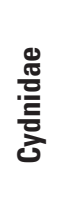 & 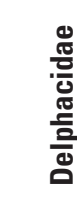 & & 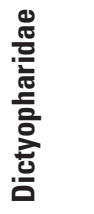 & $\begin{array}{l}\text { 을 } \\
\text { 흘 } \\
\text { 홀 }\end{array}$ & 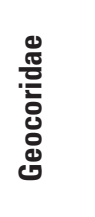 & 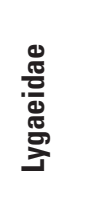 & 苋 & $\begin{array}{l}\frac{0}{\pi} \\
\frac{\pi}{0} \\
\frac{\pi}{2}\end{array}$ & 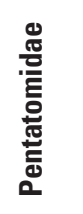 & 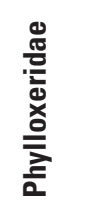 & 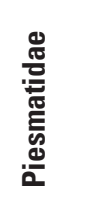 & 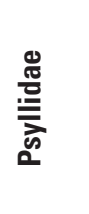 & 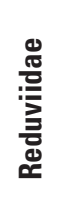 & 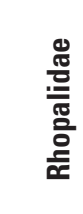 & 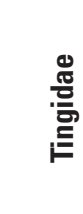 & & $\frac{\infty}{\frac{\infty}{\pi}}$ \\
\hline VE U20 & 10 & 71 & & 2 & 4 & 412 & & & & & & & 5 & 25 & 48 & & & & 4 & & & 1 & & 582 \\
\hline VE T01 & 6 & 7 & & & 3 & 324 & & & & & 5 & & 6 & 12 & 15 & & & & & & 1 & & 3 & 382 \\
\hline VE T03 & 17 & 5 & & & & 422 & & & & & & & & & & & & & & & 1 & & & 445 \\
\hline VE T06 & & 19 & & & & 1,659 & & & 2 & & 11 & & 35 & & 8 & & & & 125 & & & & & 1,859 \\
\hline VE T08 & 12 & 10 & & & 4 & 317 & & & & 4 & & & 2 & 6 & 6 & & & & 4 & & & & & 365 \\
\hline Totals & 46,681 & 619 & & 3 & 251 & 19,992 & & 5 & 2 & 181 & 31 & 63 & 166 & 3,740 & 884 & 4 & 4 & 1 & 191 & & 9 & 3 & 4 & 72,834 \\
\hline
\end{tabular}




\section{Appendix B: Aquatic Taxa Collected}




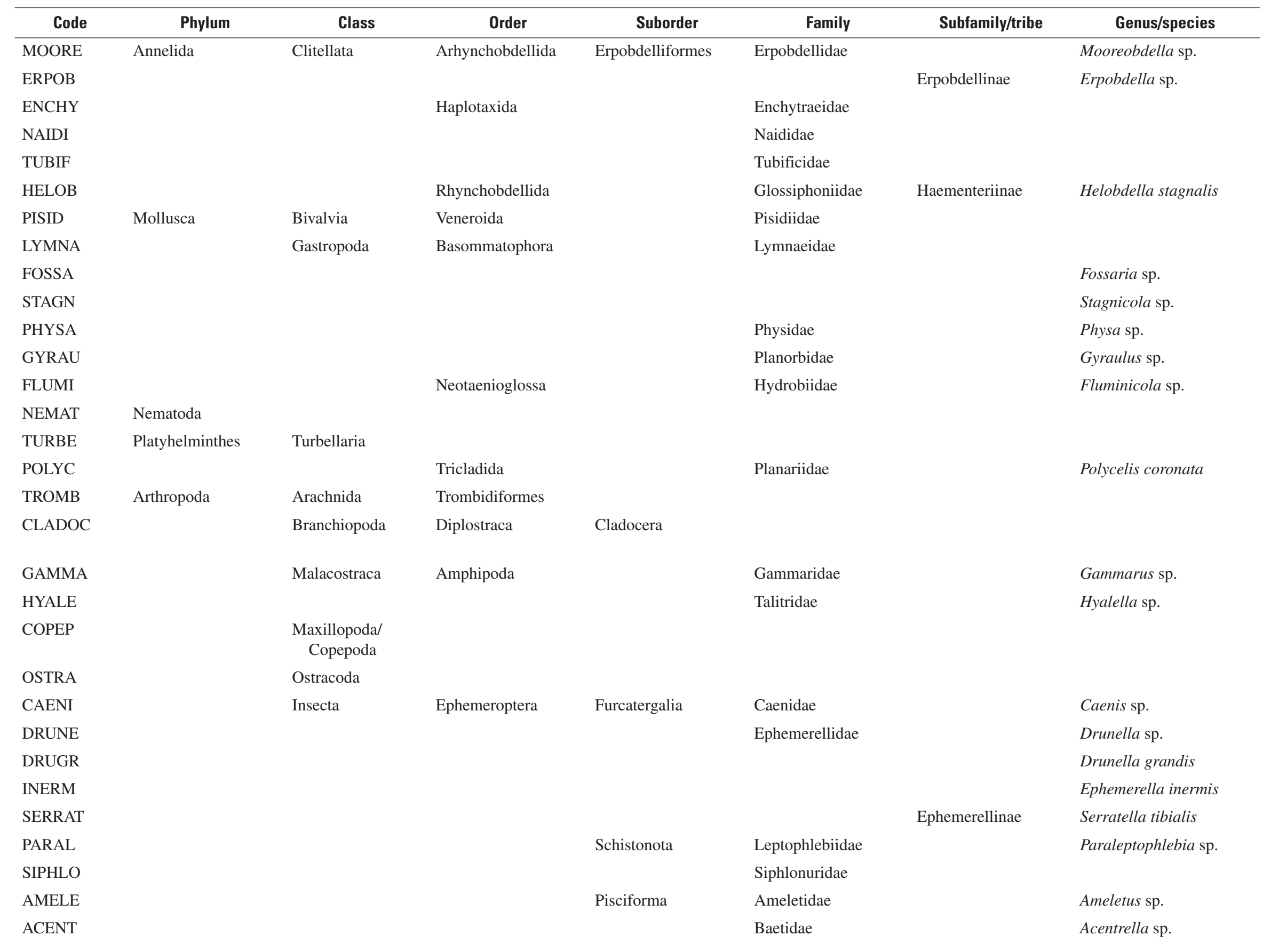




\begin{tabular}{|c|c|c|c|c|c|c|c|}
\hline Code & Phylum & Class & Order & Suborder & Family & Subfamily/tribe & Genus/species \\
\hline BAETI & & & & & & & Baetis tricaudatus \\
\hline CALLI & & & & & & & Callibaetis sp. \\
\hline CENTR & & & & & & & Centroptilum sp. \\
\hline DIPHE & & & & & & & Diphetor hageni \\
\hline CINYG & & & & Setisura & Heptageniidae & & Cinygmula sp. \\
\hline EGRAND & & & & & & & Epeorus grandis \\
\hline EDECEPT & & & & & & & Epeorus deceptivus \\
\hline ELONGIM & & & & & & & Epeorus longimanus \\
\hline AESHN & & & Odonata & Anisoptera & Aeshnidae & & \\
\hline AESHNSP & & & & & & & Aeshna sp. \\
\hline ANAXSP & & & & & & & Anax sp. \\
\hline LIBEL & & & & & Libellulidae & & \\
\hline ERYTHEM & & & & & & & Erythemis sp. \\
\hline LIBELSP & & & & & & & Libellula sp. \\
\hline SYMPE & & & & & & & Sympetrum sp. \\
\hline HETAER & & & & Zygoptera & Calopterygidae & & Hetaerina sp. \\
\hline COENAGR & & & & & Coenagrionidae & & \\
\hline AMPHIAG & & & & & & & Amphiagrion sp. \\
\hline ENALLAG & & & & & & & Enallagma sp. \\
\hline LESTES & & & & & Lestidae & & Lestes sp. \\
\hline CAPNII & & & Plecoptera & Euholognatha & Capniidae & & \\
\hline NEMOU & & & & & Nemouridae & & \\
\hline MALENKA & & & & & & Amphinemurinae & Malenka sp. \\
\hline ZAPAD & & & & & & Nemourinae & Zapada sp. \\
\hline ZAPACI & & & & & & & Zapada cinctipes \\
\hline ZAPACOL & & & & & & & Zapada columbiana \\
\hline ZAPAOR & & & & & & & Zapada oregonensis \\
\hline TAENIOP & & & & & Taeniopterygidae & Taeniopteryginae & Taeniopteryx sp. \\
\hline CHLORO & & & & Systellognatha & Chloroperlidae & & \\
\hline ISOPER & & & & & Perlodidae & Isoperlinae & Isoperla sp. \\
\hline PTERON & & & & & Pteronarcyidae & Pteronarcyinae & Pteronarcella sp. \\
\hline CORIXID & & & Heteroptera & & Corixidae & & \\
\hline CENOCOR & & & & & & & Cenocorixa sp. \\
\hline
\end{tabular}




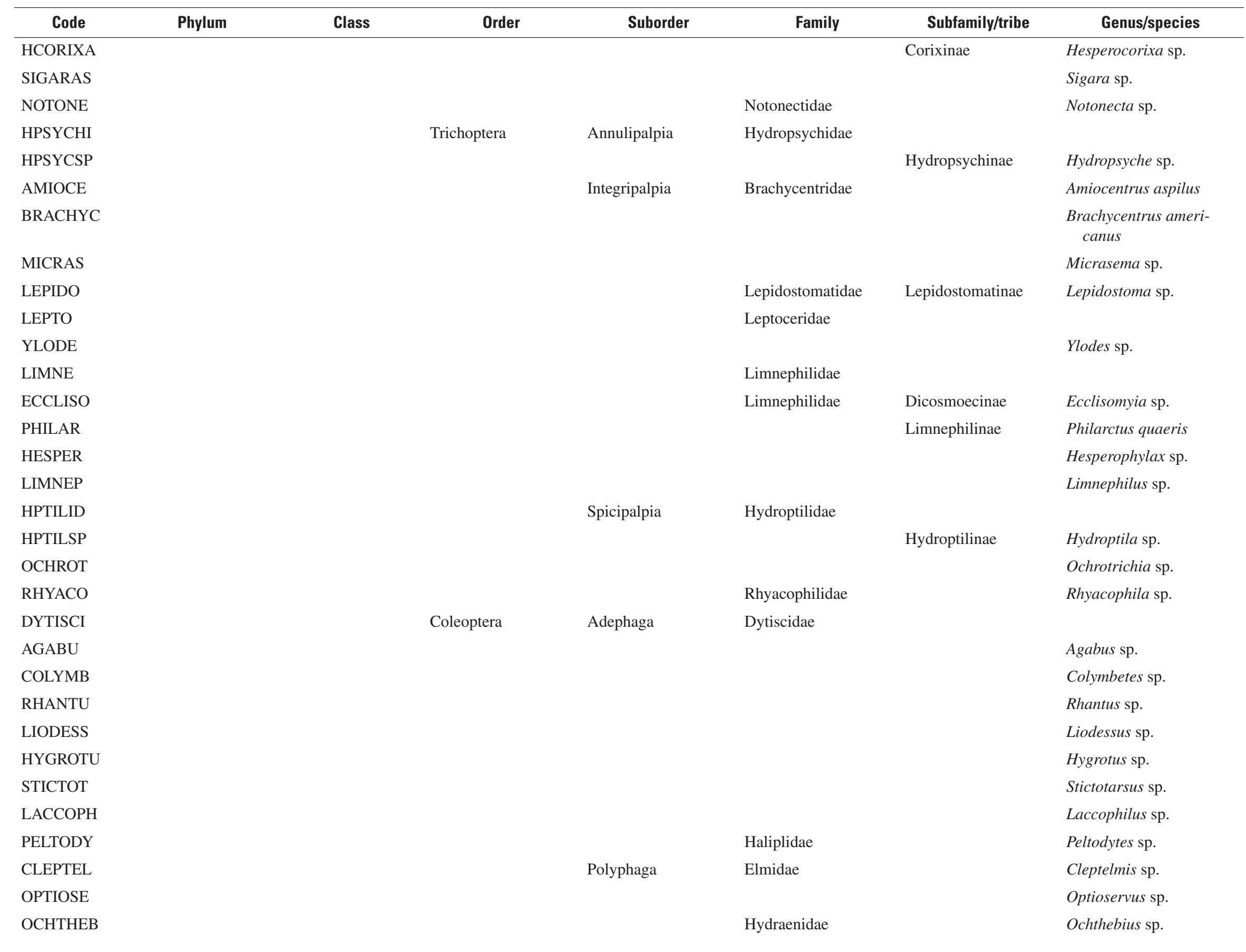




\begin{tabular}{|c|c|c|c|c|c|c|c|}
\hline Code & Phylum & Class & Order & Suborder & Family & Subfamily/tribe & Genus/species \\
\hline HPHILID & & & & & Hydrophilidae & & \\
\hline HYBIUS & & & & & & & Hydrobius sp. \\
\hline LACCOB & & & & & & & Laccobius sp. \\
\hline TROPIST & & & & & & & Tropisternus sp. \\
\hline AGATH & & & Diptera & Nematocera & Blephariceridae & Blepharicerinae & Agathon sp. \\
\hline CERATOP & & & & & Ceratopogonidae & Ceratopogoninae & \\
\hline APEDILU & & & & & Chironomidae & Chironomini & Apedilum sp. \\
\hline CHIRONO & & & & & & & Chironomus sp. \\
\hline PARACHI & & & & & & & Parachironomus sp. \\
\hline PARACLA & & & & & & & Paracladopelma sp. \\
\hline PARATEN & & & & & & & Paratendipes sp. \\
\hline PHAENOP & & & & & & & Phaenopsectra sp. \\
\hline POLYPED & & & & & & & Polypedilum sp. \\
\hline PSEUDOC & & & & & & Pseudochironomini & Pseudochironomus sp. \\
\hline TARSINI & & & & & & Tanytarsini & \\
\hline CLADOT & & & & & & & Cladotanytarsus sp. \\
\hline MICROPS & & & & & & & Micropsectra sp. \\
\hline RHEOTAN & & & & & & & Rheotanytarsus sp. \\
\hline STEMPEL & & & & & & & Stempellinella sp. \\
\hline TANYTAR & & & & & & & Tanytarsus sp. \\
\hline PAGAS & & & & & & Diamesinae & Pagastia sp. \\
\hline IAMESA & & & & & & & Pseudodiamesa sp. \\
\hline DIAMES & & & & & & & Diamesa sp. \\
\hline ACRICOT & & & & & & Orthocladiinae & Acricotopus sp. \\
\hline BRILLIA & & & & & & & Brillia sp. \\
\hline СНAETOC & & & & & & & Chaetocladius sp. \\
\hline CORYNON & & & & & & & Corynoneura sp. \\
\hline CRICOTO & & & & & & & Cricotopus (Cricotopus) \\
\hline ISOCLAD & & & & & & & Cricotopus (Isocladius) \\
\hline EUKBREH & & & & & & & Eukiefferiella brehmi gr. \\
\hline EUKDEVO & & & & & & & $\begin{array}{l}\text { Eukiefferiella devonica } \\
\text { gr. }\end{array}$ \\
\hline EUKGRAC & & & & & & & Eukiefferiella gracei gr. \\
\hline
\end{tabular}




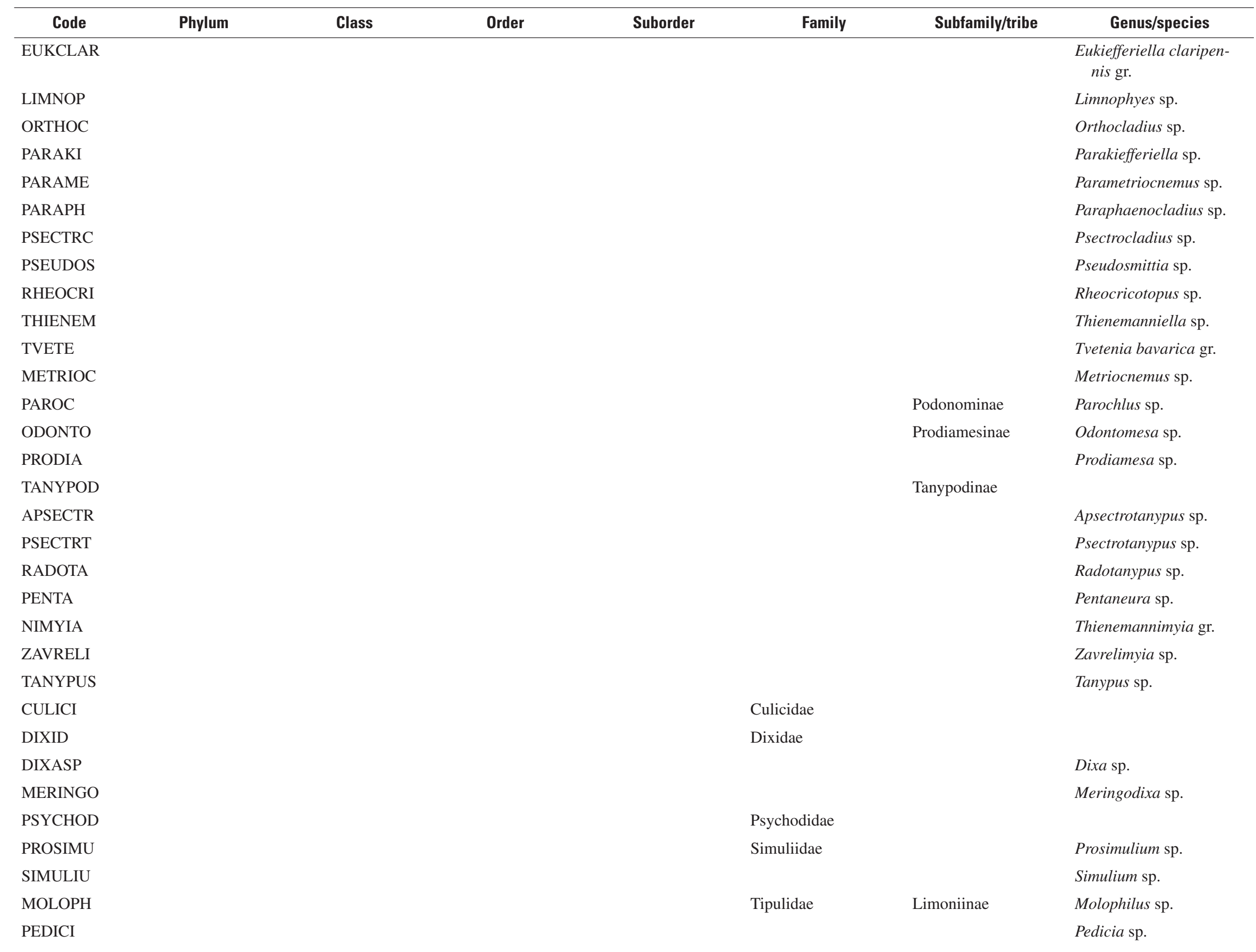




\begin{tabular}{|c|c|c|c|c|c|c|c|}
\hline Code & Phylum & Class & Order & Suborder & Family & Subfamily/tribe & Genus/species \\
\hline DICRAN & & & & & & & Dicranota sp. \\
\hline TIPULA & & & & & & Tipulinae & Tipula sp. \\
\hline DOLICHO & & & & Brachycera & Dolichopodidae & & \\
\hline EMPIDI & & & & & Empididae & & \\
\hline NEOPLAS & & & & & & & Neoplasta sp. \\
\hline CLINOCE & & & & & & & Clinocera sp. \\
\hline EPHYDR & & & & & Ephydridae & & \\
\hline MUSCIDA & & & & & Muscidae & & \\
\hline SCIOMYZ & & & & & Sciomyzidae & & \\
\hline
\end{tabular}




\begin{tabular}{|c|c|c|c|c|c|c|c|c|c|c|c|c|c|c|c|c|c|c|c|c|c|}
\hline \multirow[b]{2}{*}{ Code } & \multicolumn{3}{|c|}{ CMSP1 } & \multicolumn{3}{|c|}{ CMSP2 } & \multicolumn{2}{|c|}{ CLSP1 } & \multicolumn{2}{|c|}{ CLSP2 } & \multicolumn{2}{|c|}{ RBTST } & \multirow{2}{*}{$\begin{array}{c}\text { NFRST } \\
10 / 7 \\
\end{array}$} & \multicolumn{3}{|c|}{ KGSP } & \multicolumn{3}{|c|}{ LRSP } & \multicolumn{2}{|c|}{ RBNST } \\
\hline & $5 / 25$ & $6 / 24$ & $10 / 7$ & $5 / 25$ & $6 / 24$ & $10 / 7$ & $5 / 26$ & $10 / 6$ & $6 / 23$ & $10 / 6$ & $5 / 27$ & $6 / 22$ & & $5 / 25$ & $6 / 23$ & $10 / 7$ & $6 / 2$ & $6 / 22$ & $10 / 7$ & $6 / 2$ & $6 / 22$ \\
\hline \multicolumn{22}{|l|}{ MOORE } \\
\hline \multicolumn{22}{|l|}{ ERPOB } \\
\hline ENCHY & 90 & & & & & & & & 15 & & & 30 & 10 & & & & 30 & 20 & & & \\
\hline NAIDI & & & & & & & & & & & & & 90 & & & & 180 & 390 & & & \\
\hline TUBIF & 1,185 & 1,484 & 70 & 1,395 & 40 & 20 & 7 & & 30 & & & 8 & & 5 & 320 & & 960 & 330 & & & \\
\hline \multicolumn{22}{|l|}{ HELOB } \\
\hline PISID & & & & & 20 & & & & & & 6 & & & & & & & & & & \\
\hline LYMNA & 15 & 32 & & 15 & & & & & 75 & & & & & & & & 30 & & & & \\
\hline FOSSA & & & & & & & 14 & & & & & & & 1 & & & & 10 & & & \\
\hline STAGN & & & 10 & & 80 & & & 48 & & 110 & & & 30 & & & & & & 26 & & \\
\hline \multicolumn{22}{|l|}{ PHYSA } \\
\hline GYRAU & & & & & & & & & & & & & & & & & & & 90 & & \\
\hline FLUMI & 315 & & & 15 & 680 & 80 & & & & & & & & & & & & & & & \\
\hline NEMAT & 60 & & & & & & & & & & 11 & 8 & 10 & 13 & & & 615 & 130 & & & \\
\hline TURBE & & & & & & & 5 & & & 5 & & & & & & & & & & & \\
\hline \multicolumn{22}{|l|}{ POLYC } \\
\hline TROMB & & & & & & & & & & 5 & & 15 & 10 & & & & & & & 10 & \\
\hline CLADOC & 60 & 63 & 1,820 & 90 & 100 & 1,070 & 58 & & 15 & 240 & & 8 & 5 & & & 7,306 & 45 & 1150 & 32 & 10 & \\
\hline \multicolumn{22}{|l|}{ GAMMA } \\
\hline HYALE & 15 & & & & 20 & & & & & & & & 10 & & & & & & & & \\
\hline COPEP & & & 10 & & 40 & & 14 & 72 & 180 & & & 8 & 165 & & & & & & & & \\
\hline OSTRA & 2,235 & 6,821 & 110 & 2,715 & 4,560 & 630 & 595 & 243 & 2,310 & 230 & 6 & & 35 & 150 & 2,620 & 671 & 2,655 & 700 & 276 & 20 & \\
\hline CAENI & & & 10 & & & 10 & & & & & & & & & & & & & & & \\
\hline DRUNE & & & & & & & & & & & & 60 & & & & & & & & & 5 \\
\hline DRUGR & & & & & & & & & & & & & 30 & & & & & & & & \\
\hline INERM & & & & & & & & & & & 11 & 98 & 10 & & & & & & & 50 & 48 \\
\hline SERRAT & & & & & & & & & & & 6 & & & & & & & & & & \\
\hline \multicolumn{22}{|l|}{ PARAL } \\
\hline SIPHLO & & & & & & & & & & & & & & & & & & & & 10 & \\
\hline AMELE & & & & & & & & & & & 29 & 30 & & & & & & & & 10 & \\
\hline
\end{tabular}


Grouse Creek sites-Continued.

\begin{tabular}{|c|c|c|c|c|c|c|c|c|c|c|c|c|c|c|c|c|c|c|c|c|c|}
\hline \multirow[b]{2}{*}{ Code } & \multicolumn{3}{|c|}{ CMSP1 } & \multicolumn{3}{|c|}{ CMSP2 } & \multicolumn{2}{|c|}{ CLSP1 } & \multicolumn{2}{|c|}{ CLSP2 } & \multicolumn{2}{|c|}{ RBTST } & \multirow{2}{*}{$\begin{array}{c}\text { NFRST } \\
10 / 7 \\
\end{array}$} & \multicolumn{3}{|c|}{ KGSP } & \multicolumn{3}{|c|}{ LRSP } & \multicolumn{2}{|c|}{ RBNST } \\
\hline & $5 / 25$ & $6 / 24$ & $10 / 7$ & $5 / 25$ & $6 / 24$ & $10 / 7$ & $5 / 26$ & $10 / 6$ & $6 / 23$ & $10 / 6$ & $5 / 27$ & $6 / 22$ & & $5 / 25$ & $6 / 23$ & $10 / 7$ & $6 / 2$ & $6 / 22$ & $10 / 7$ & $6 / 2$ & $6 / 22$ \\
\hline ACENT & & & & & & & & & & & 217 & 195 & & & & & & & & 212 & 21 \\
\hline BAETI & & & & & & & & 2 & & & 109 & 773 & & & & & & & & & 380 \\
\hline CALLI & 30 & 411 & 820 & 30 & 340 & 1,010 & & 88 & 225 & 875 & 6 & & 160 & & & 2,718 & & 10 & 105 & & \\
\hline CENTR & & & & & & & & & & & & & & & & & & & & 268 & 16 \\
\hline \multicolumn{22}{|l|}{ DIPHE } \\
\hline CINYG & & & & & & & & & & & 11 & & & & & & & & & & \\
\hline \multicolumn{22}{|l|}{ EGRAND } \\
\hline \multicolumn{22}{|l|}{ EDECEPT } \\
\hline ELONGIM & & & & & & & & & & & & 8 & & & & & & & & & \\
\hline AESHN & & & & & & & & & & & & & & & & & & 10 & & & \\
\hline AESHNSP & & 32 & 20 & & 20 & & & & & & & & & & & & & & & & \\
\hline ANAXSP & & & & & & 10 & & & & & & & & & & & & & 4 & & \\
\hline LIBEL & 15 & & & & & & & & 45 & & & & & & & & & 20 & 6 & & \\
\hline ERYTHEM & & & 60 & & 20 & 35 & & & & & & & & & & & & & & & \\
\hline LIBELSP & & 32 & & & & & & & & & & & & & & & & & & & \\
\hline SYMPE & & 32 & & 15 & & 35 & & & & & & & & & & 35 & & & & & \\
\hline \multicolumn{22}{|l|}{ HETAER } \\
\hline COENAGR & & & & & & & & & 30 & & & & & & & & & & & & \\
\hline AMPHIAG & 15 & & & 15 & 60 & & & 20 & & & & & & & & 71 & & & 11 & & \\
\hline ENALLAG & 15 & 189 & 110 & 30 & 40 & 220 & & & & 145 & & & & & & 282 & & & 15 & & \\
\hline \multicolumn{22}{|l|}{ LESTES } \\
\hline CAPNII & & & & & & & & & & & & & 5 & & & & & & & & \\
\hline NEMOU & & & & & & & & & & & & 30 & & & & & & & & & \\
\hline \multicolumn{22}{|l|}{ MALENKA } \\
\hline \multicolumn{22}{|l|}{ ZAPAD } \\
\hline ZAPACI & & & & & & & & & & & & & 60 & & & & & & & & 5 \\
\hline \multicolumn{22}{|l|}{ ZAPACOL } \\
\hline \multicolumn{22}{|l|}{ ZAPAOR } \\
\hline TAENIOP & & & & & & & & & & & & 15 & & & & & & & & & \\
\hline CHLORO & & & & & & & & & & & 6 & & & & & & & & & & \\
\hline
\end{tabular}




\begin{tabular}{|c|c|c|c|c|c|c|c|c|c|c|c|c|c|c|c|c|c|c|c|c|c|}
\hline \multirow[b]{2}{*}{ Code } & \multicolumn{3}{|c|}{ CMSP1 } & \multicolumn{3}{|c|}{ CMSP2 } & \multicolumn{2}{|c|}{ CLSP1 } & \multicolumn{2}{|c|}{ CLSP2 } & \multicolumn{2}{|c|}{ RBTST } & \multirow{2}{*}{$\begin{array}{c}\text { NFRST } \\
10 / 7 \\
\end{array}$} & \multicolumn{3}{|c|}{ KGSP } & \multicolumn{3}{|c|}{ LRSP } & \multicolumn{2}{|c|}{ RBNST } \\
\hline & $5 / 25$ & $6 / 24$ & $10 / 7$ & $5 / 25$ & $6 / 24$ & $10 / 7$ & $5 / 26$ & $10 / 6$ & $6 / 23$ & $10 / 6$ & $5 / 27$ & $6 / 22$ & & $5 / 25$ & $6 / 23$ & $10 / 7$ & $6 / 2$ & $6 / 22$ & $10 / 7$ & $6 / 2$ & $6 / 22$ \\
\hline \multicolumn{22}{|l|}{ ISOPER } \\
\hline \multicolumn{22}{|l|}{ PTERON } \\
\hline CORIXID & 15 & 95 & & & 200 & & & & 45 & & & & & & & & 15 & 60 & & & \\
\hline CENOCOR & & & & & & & & 2 & & & & & & & & & & & & & \\
\hline HCORIXA & & & 20 & & & 10 & & & & & & & & & 30 & 35 & & & & & \\
\hline SIGARAS & & & & & & & & & & 5 & & & & & & & & & & & \\
\hline NOTONE & 15 & 32 & 10 & 120 & 20 & 10 & & 7 & & 5 & & & & & 20 & 35 & & 60 & 2 & & \\
\hline \multicolumn{22}{|l|}{ HPSYCHI } \\
\hline HPSYCSP & & & & & & & & & & & & 8 & & & & & & & & & \\
\hline AMIOCE & & & & & & & & & & & 11 & 8 & & & & & & & & 10 & \\
\hline \multicolumn{22}{|l|}{ BRACHYC } \\
\hline \multicolumn{22}{|l|}{ MICRAS } \\
\hline \multicolumn{22}{|l|}{ LEPIDO } \\
\hline LEPTO & & & & & & & & & & & 6 & & & & & & & & & & \\
\hline YLODE & & & & & & & & & & & & 8 & & & & & & & & 20 & \\
\hline LIMNE & & & 10 & & & 10 & & 2 & & & & & & & & & & & & & \\
\hline \multicolumn{22}{|l|}{ ECCLISO } \\
\hline PHILAR & & & & & & & & & & & & 8 & & & & & & & & & \\
\hline HESPER & & & & & & & & & & & & 8 & & & & & & & & & \\
\hline LEPHILU & & & & & & & & & & & & & 20 & & & & & & & & \\
\hline HPTILID & & & & & & & & & & & & & & & & & & & & 10 & \\
\hline \multicolumn{22}{|l|}{ HPTILSP } \\
\hline \multicolumn{22}{|l|}{ OCHROT } \\
\hline \multicolumn{22}{|l|}{ RHYACO } \\
\hline DYTISCI & & 63 & & & & & 7 & & 105 & & 6 & & & 14 & & & & & & & 11 \\
\hline AGABU & & & 20 & & 50 & & & & & & & & 5 & & & & & & & & \\
\hline COLYMB & & & & & & & & & & & & & & & & 35 & & & & & \\
\hline RHANTU & & & 20 & & & & & 7 & & 5 & & & 10 & & & 35 & 15 & 30 & 2 & & \\
\hline LIODESS & & & & & & & & & & & & & & & & & & & & & \\
\hline HYGROTU & & & & & & & & & & & & & & & & & & & & & \\
\hline
\end{tabular}


Grouse Creek sites-Continued.

\begin{tabular}{|c|c|c|c|c|c|c|c|c|c|c|c|c|c|c|c|c|c|c|c|c|c|}
\hline \multirow[b]{2}{*}{ Code } & \multicolumn{3}{|c|}{ CMSP1 } & \multicolumn{3}{|c|}{ CMSP2 } & \multicolumn{2}{|c|}{ CLSP1 } & \multicolumn{2}{|c|}{ CLSP2 } & \multicolumn{2}{|c|}{ RBTST } & \multirow{2}{*}{$\begin{array}{c}\text { NFRST } \\
10 / 7\end{array}$} & \multicolumn{3}{|c|}{ KGSP } & \multicolumn{3}{|c|}{ LRSP } & \multicolumn{2}{|c|}{ RBNST } \\
\hline & $5 / 25$ & $6 / 24$ & $10 / 7$ & $5 / 25$ & $6 / 24$ & $10 / 7$ & $5 / 26$ & $10 / 6$ & $6 / 23$ & $10 / 6$ & $5 / 27$ & $6 / 22$ & & $5 / 25$ & $6 / 23$ & $10 / 7$ & $6 / 2$ & $6 / 22$ & $10 / 7$ & $6 / 2$ & $6 / 22$ \\
\hline STICTOT & & & & & & & & & & & & 30 & 10 & & 40 & & & & & & \\
\hline LACCOPH & & & & 15 & 50 & & & 2 & & 5 & & & 5 & & & 71 & & & & & \\
\hline PELTODY & & 32 & & & 40 & & & & & & & & & & & & & & & & \\
\hline \multicolumn{22}{|l|}{ CLEPTEL } \\
\hline OPTIOSE & & & & & & & & & & & & & 10 & & & & & & & & \\
\hline ОСНТНЕВ & & & & & & & & & & & & & 10 & & & & & & & & \\
\hline HPHILID & & & & & & & & & & & & & & & & & & 10 & & & \\
\hline HYBIUS & & & & & & & & & & & & & & & 20 & & & & & & \\
\hline LACCOB & & & & & & & & & & & & & 10 & & & & 15 & & & & \\
\hline TROPIST & & 63 & 10 & & & 10 & & & & & & & & 1 & & & & & & & \\
\hline AGATH & & & & & & & & & & & 6 & & & & & & & & & & \\
\hline CERATOP & 30 & & & 45 & & & & & & & & 8 & & & & & & & & 20 & \\
\hline APEDILU & 15 & & & & & 10 & 2 & 5 & 459 & 8 & 6 & & 77 & 3 & & 318 & & & & & \\
\hline CHIRONO & 15 & & & 62 & & 10 & & & 126 & & & & & & 110 & & 60 & 10 & & & \\
\hline \multicolumn{22}{|l|}{ PARACHI } \\
\hline \multicolumn{22}{|l|}{ PARACLA } \\
\hline PARATEN & & & & & & & & & & & & & & & & & & & & 11 & \\
\hline PHAENOP & & & & & & & & & & & & & 41 & & & & & & & & \\
\hline POLYPED & & & & & & 10 & & & & & & & & & & & & & & 33 & \\
\hline PSEUDOC & 45 & 411 & 257 & 109 & 400 & 40 & & & & 17 & & & & & & 35 & & & & & \\
\hline TARSINI & & & & & & & & 2 & & & & & & & & & & 10 & & & \\
\hline \multicolumn{22}{|l|}{ CLADOT } \\
\hline MICROPS & 135 & 474 & & 31 & & & 14 & & 1,123 & & 12 & & 429 & 2 & & 35 & 195 & & 4 & 22 & \\
\hline RHEOTAN & & & & & & & & & & & 6 & & 5 & & & & & & & 11 & \\
\hline STEMPEL & & & & & & & & & & & & 20 & & & & & & & & & \\
\hline TANYTAR & & & & & & & & & & & 12 & 10 & 47 & & & & & & & 65 & \\
\hline PAGAS & & & & & & & & & & & 6 & & 5 & & & & & & & & 6 \\
\hline \multicolumn{22}{|l|}{ IAMESA } \\
\hline DIAMES & & & & & & & & & & & 54 & 79 & & & & & & & & 76 & \\
\hline ACRICOT & 385 & & & 117 & & & & & & 17 & & & & & & & & & 30 & & \\
\hline
\end{tabular}


Grouse Creek sites-Continued.

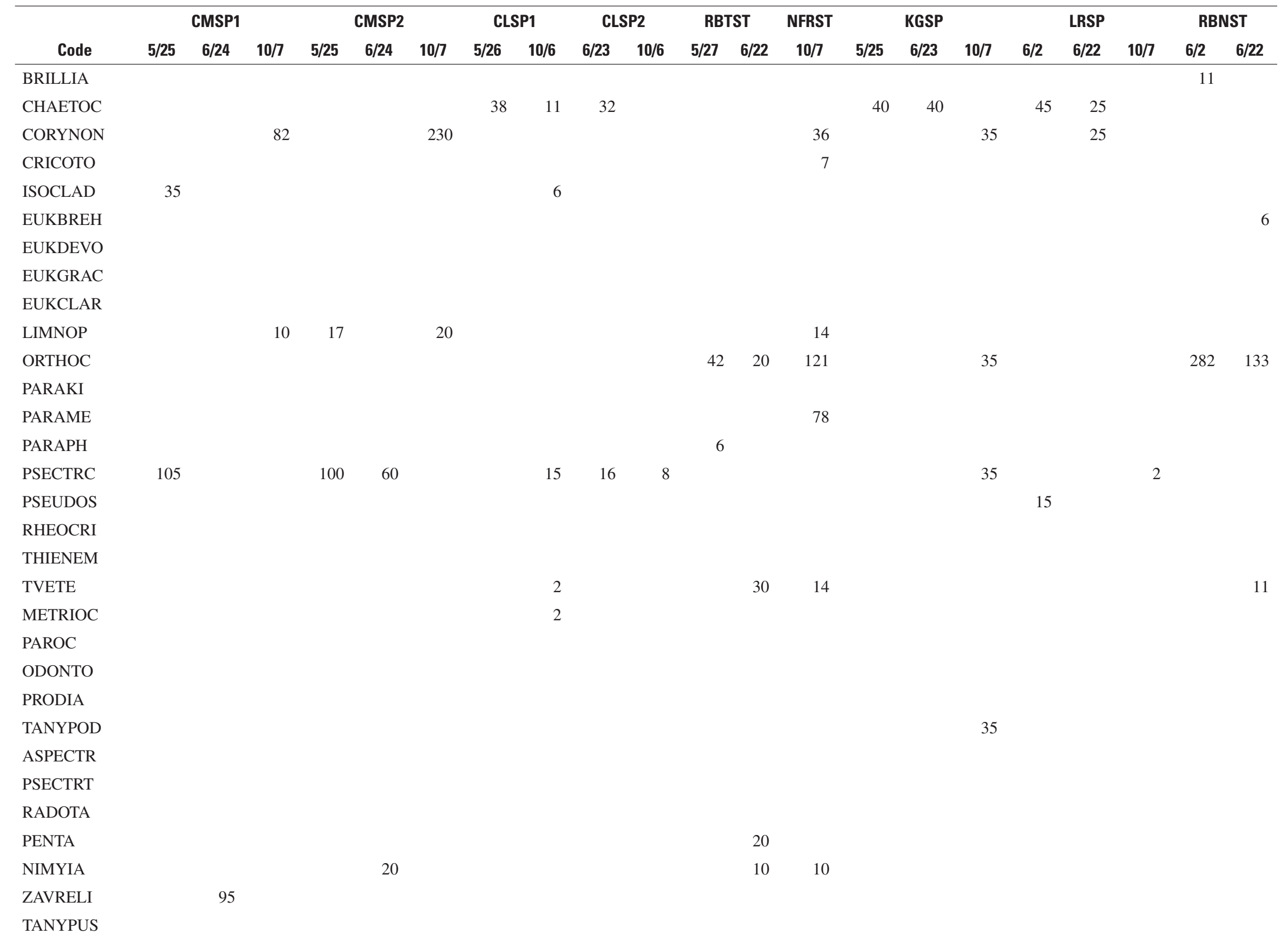


Grouse Creek sites-Continued.

\begin{tabular}{|c|c|c|c|c|c|c|c|c|c|c|c|c|c|c|c|c|c|c|c|c|c|}
\hline \multirow[b]{2}{*}{ Code } & \multicolumn{3}{|c|}{ CMSP1 } & \multicolumn{3}{|c|}{ CMSP2 } & \multicolumn{2}{|c|}{ CLSP1 } & \multicolumn{2}{|c|}{ CLSP2 } & \multicolumn{2}{|c|}{ RBTST } & \multirow{2}{*}{$\begin{array}{c}\text { NFRST } \\
10 / 7\end{array}$} & \multicolumn{3}{|c|}{ KGSP } & \multicolumn{3}{|c|}{ LRSP } & \multicolumn{2}{|c|}{ RBNST } \\
\hline & $5 / 25$ & $6 / 24$ & $10 / 7$ & $5 / 25$ & $6 / 24$ & $10 / 7$ & $5 / 26$ & $10 / 6$ & $6 / 23$ & $10 / 6$ & $5 / 27$ & $6 / 22$ & & $5 / 25$ & $6 / 23$ & $10 / 7$ & $6 / 2$ & $6 / 22$ & $10 / 7$ & $6 / 2$ & $6 / 22$ \\
\hline CULICI & & & & & & & 19 & & & & & & & & & & & & & & \\
\hline \multicolumn{22}{|l|}{ DIXID } \\
\hline \multicolumn{22}{|l|}{ DIXASP } \\
\hline MERINGO & & & & & & & & & & & & 8 & & & & & & & & & \\
\hline PSYCHOD & & & & & & & 2 & & & & & & & & & & & & & & \\
\hline PROSIMU & & & & & & & & & & & 223 & 9 & & & & & & & & 141 & 38 \\
\hline SIMULIU & & & & & & & & & & & 1,074 & 958 & 40 & & & 35 & & & & 1,869 & 1,103 \\
\hline \multicolumn{22}{|l|}{ MOLOPH } \\
\hline \multicolumn{22}{|l|}{ PEDICI } \\
\hline \multicolumn{22}{|l|}{ DICRAN } \\
\hline TIPULA & & & & & & & & & & & & & 10 & & & & & & & & \\
\hline DOLICHO & & & & & & & 5 & & & & & & & 5 & & & & & & & \\
\hline \multicolumn{22}{|l|}{ EMPIDI } \\
\hline \multicolumn{22}{|l|}{ NEOPLAS } \\
\hline CLINOCE & & & & & & & & & & & & & & 2 & & & & & & & \\
\hline EPHYDR & & & & & & & & & & & & 8 & 10 & 20 & & & & & & & 5 \\
\hline MUSCIDA & & & & & & & & & & & & 8 & 30 & & 10 & & & & & & 11 \\
\hline SCIOMYZ & & & & & & & 2 & & & & & & & & & & & & & & \\
\hline
\end{tabular}


74 Mormon Cricket Control in Utah's West Desert-Evaluation of Impacts of the Pesticide Diflubenzuron

Ibapah sites

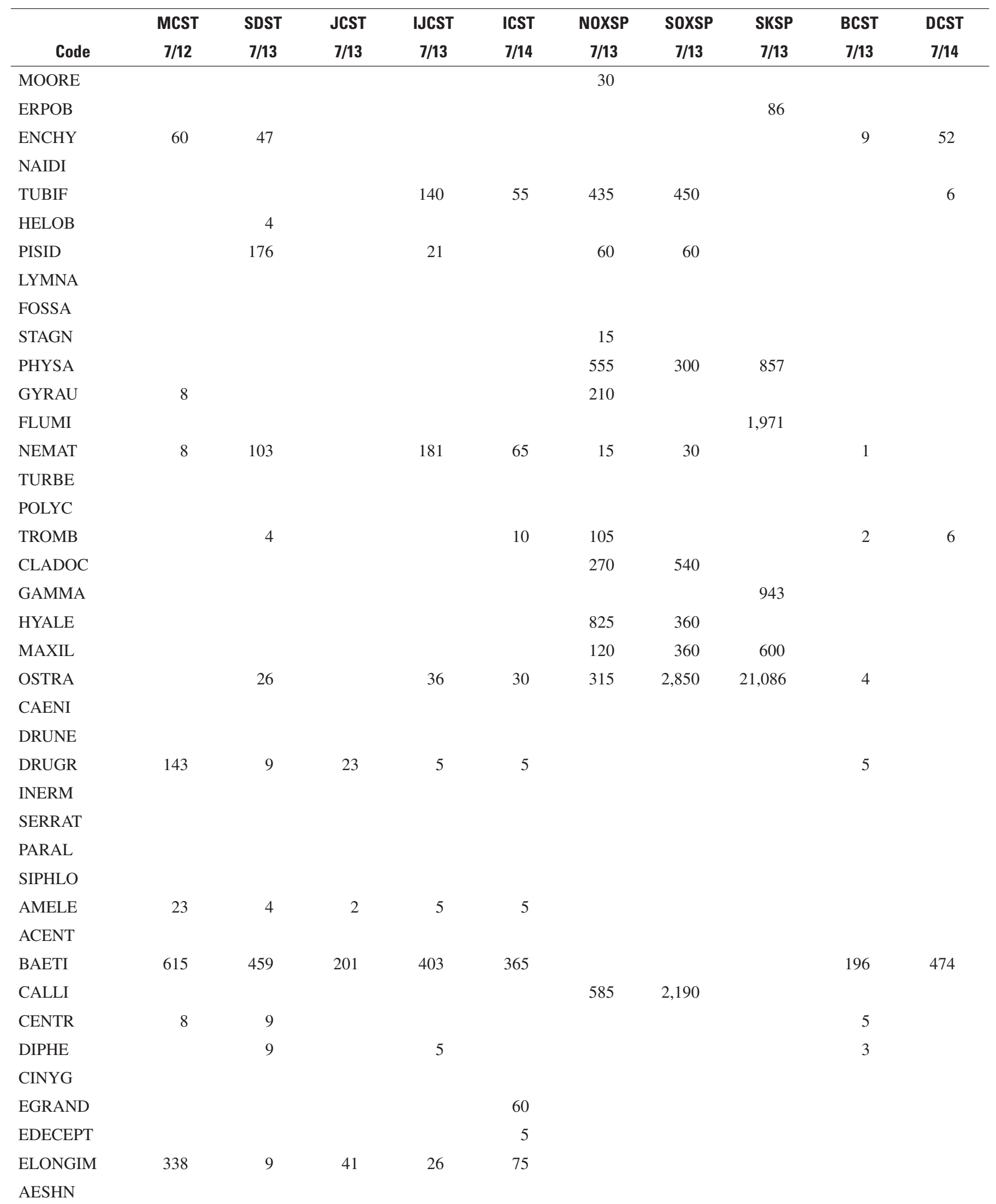


Ibapah sites-Continued.

\begin{tabular}{|c|c|c|c|c|c|c|c|c|c|c|}
\hline Code & $\begin{array}{c}\text { MCST } \\
7 / 12\end{array}$ & $\begin{array}{c}\text { SDST } \\
7 / 13\end{array}$ & $\begin{array}{c}\text { JCST } \\
7 / 13\end{array}$ & $\begin{array}{c}\text { IJCST } \\
7 / 13\end{array}$ & $\begin{array}{l}\text { ICST } \\
7 / 14\end{array}$ & $\begin{array}{c}\text { NOXSP } \\
7 / 13\end{array}$ & $\begin{array}{c}\text { SOXSP } \\
7 / 13\end{array}$ & $\begin{array}{c}\text { SKSP } \\
7 / 13\end{array}$ & $\begin{array}{c}\text { BCST } \\
7 / 13\end{array}$ & $\begin{array}{c}\text { DCST } \\
7 / 14\end{array}$ \\
\hline \multicolumn{11}{|l|}{ AESHNSP } \\
\hline \multicolumn{11}{|l|}{ LIBEL } \\
\hline \multicolumn{11}{|l|}{ ERYTHEM } \\
\hline SYMPE & & & & & & 15 & 30 & & & \\
\hline HETAER & & & & & & & 30 & & & \\
\hline \multicolumn{11}{|l|}{ COENAGR } \\
\hline \multicolumn{11}{|l|}{ AMPHIAG } \\
\hline \multicolumn{11}{|l|}{ NEMOU } \\
\hline MALENKA & & & 2 & & 5 & & & & 1 & \\
\hline \multicolumn{11}{|l|}{ ZAPAD } \\
\hline \multicolumn{11}{|l|}{ ZAPACI } \\
\hline \multicolumn{11}{|l|}{ ZAPACOL } \\
\hline \multicolumn{11}{|l|}{ ZAPAOR } \\
\hline \multicolumn{11}{|l|}{ TAENIOP } \\
\hline \multicolumn{11}{|l|}{ CHLORO } \\
\hline NOTONE & & & & & 5 & 15 & 90 & & & \\
\hline HPSYCHI & & & 2 & & & & & & & \\
\hline HPSYCSP & & & & 10 & 5 & & & & & \\
\hline \multicolumn{11}{|l|}{ AMIOCE } \\
\hline BRACHYC & & & 3 & & & & & & & \\
\hline MICRAS & 285 & & 5 & & & & & & 1 & \\
\hline \multicolumn{11}{|l|}{ LEPIDO } \\
\hline \multicolumn{11}{|l|}{ LEPTO } \\
\hline \multicolumn{11}{|l|}{ YLODE } \\
\hline LIMNE & & & & & & & & & & \\
\hline ECCLISO & 8 & & 2 & & & & & & & \\
\hline PHILAR & & & & & & & & & & \\
\hline HESPER & & & & & & & & & & \\
\hline LEPHILU & & & & & & & & 171 & & \\
\hline HPTILID & & & & & & & & & & \\
\hline
\end{tabular}


Ibapah sites-Continued.

\begin{tabular}{|c|c|c|c|c|c|c|c|c|c|c|}
\hline Code & $\begin{array}{c}\text { MCST } \\
7 / 12\end{array}$ & $\begin{array}{c}\text { SDST } \\
7 / 13\end{array}$ & $\begin{array}{c}\text { JCST } \\
7 / 13\end{array}$ & $\begin{array}{c}\text { IJCST } \\
7 / 13\end{array}$ & $\begin{array}{l}\text { ICST } \\
7 / 14\end{array}$ & $\begin{array}{c}\text { NOXSP } \\
7 / 13\end{array}$ & $\begin{array}{c}\text { SOXSP } \\
7 / 13\end{array}$ & $\begin{array}{l}\text { SKSP } \\
7 / 13\end{array}$ & $\begin{array}{c}\text { BCST } \\
7 / 13\end{array}$ & $\begin{array}{c}\text { DCST } \\
7 / 14\end{array}$ \\
\hline HPTILSP & & 4 & & 31 & 5 & & & & & 9 \\
\hline OCHROT & 8 & & & & & & & & 3 & \\
\hline \multicolumn{11}{|l|}{ RHYACO } \\
\hline DYTISCI & & 47 & 11 & 5 & & 75 & & & & \\
\hline AGABU & 53 & & & & 10 & & & & & \\
\hline \multicolumn{11}{|l|}{ COLYMB } \\
\hline \multicolumn{11}{|l|}{ RHANTU } \\
\hline LIODESS & & & & & & & 150 & & & 34 \\
\hline HYGROTU & & & & & & & & & 4 & \\
\hline STICTOT & & & & & & & & & 12 & \\
\hline \multicolumn{11}{|l|}{ LACCOPH } \\
\hline \multicolumn{11}{|l|}{ PELTODY } \\
\hline \multicolumn{11}{|l|}{ CLEPTEL } \\
\hline OPTIOSE & & & & & 15 & & & & & \\
\hline \multicolumn{11}{|l|}{ OCHTHEB } \\
\hline HPHILID & & 4 & & 10 & & & & & & \\
\hline \multicolumn{11}{|l|}{ HYBIUS } \\
\hline \multicolumn{11}{|l|}{ LACCOB } \\
\hline \multicolumn{11}{|l|}{ TROPIST } \\
\hline \multicolumn{11}{|l|}{ AGATH } \\
\hline CERATOP & 15 & & 2 & & 5 & 45 & & & 1 & \\
\hline APEDILU & 8 & & & & & 46 & 90 & & & 3 \\
\hline \multicolumn{11}{|l|}{ CHIRONO } \\
\hline \multicolumn{11}{|l|}{ PARACHI } \\
\hline \multicolumn{11}{|l|}{ PARACLA } \\
\hline PARATEN & & & & & 16 & & & & & \\
\hline PHAENOP & & & & & & & & & 1 & 3 \\
\hline POLYPED & & & & & & & & 86 & & \\
\hline PSEUDOC & & & & & & 46 & & & & \\
\hline \multicolumn{11}{|l|}{ TARSINI } \\
\hline CLADOT & 8 & & & & & & & & & \\
\hline MICROPS & 8 & 10 & & 17 & & 309 & 120 & 343 & 1 & \\
\hline \multicolumn{11}{|l|}{ RHEOTAN } \\
\hline \multicolumn{11}{|l|}{ STEMPEL } \\
\hline \multicolumn{11}{|l|}{ TANYTAR } \\
\hline PAGAS & 16 & 15 & 5 & 6 & 5 & & & & & 17 \\
\hline \multicolumn{11}{|l|}{ IAMESA } \\
\hline \multicolumn{11}{|l|}{ DIAMES } \\
\hline ACRICOT & & & & & & & 103 & & & \\
\hline BRILLIA & & & & & & & & & & \\
\hline СНAETOC & & & & & & & & & & \\
\hline
\end{tabular}


Ibapah sites-Continued.

\begin{tabular}{|c|c|c|c|c|c|c|c|c|c|c|}
\hline Code & $\begin{array}{c}\text { MCST } \\
7 / 12\end{array}$ & $\begin{array}{c}\text { SDST } \\
7 / 13\end{array}$ & $\begin{array}{c}\text { JCST } \\
7 / 13\end{array}$ & $\begin{array}{c}\text { IJCST } \\
7 / 13\end{array}$ & $\begin{array}{l}\text { ICST } \\
7 / 14\end{array}$ & $\begin{array}{c}\text { NOXSP } \\
7 / 13\end{array}$ & $\begin{array}{c}\text { SOXSP } \\
7 / 13\end{array}$ & $\begin{array}{c}\text { SKSP } \\
7 / 13\end{array}$ & $\begin{array}{c}\text { BCST } \\
7 / 13\end{array}$ & $\begin{array}{r}\text { DCST } \\
7 / 14\end{array}$ \\
\hline CORYNON & & & & & & & 34 & & & \\
\hline \multicolumn{11}{|l|}{ ISOCLAD } \\
\hline EUKBREH & 39 & 20 & 5 & 91 & 5 & & & & 1 & 30 \\
\hline EUKGRAC & & & & & 71 & & & & & \\
\hline EUKCLAR & 31 & 5 & & 12 & & & & & & 3 \\
\hline LIMNOP & & & & & 11 & & & & & \\
\hline ORTHOC & 24 & 40 & 10 & 193 & 5 & & 34 & & 2 & \\
\hline \multicolumn{11}{|l|}{ PARAME } \\
\hline PSECTRC & & & & & & & 69 & & & \\
\hline \multicolumn{11}{|l|}{ PSEUDOS } \\
\hline \multicolumn{11}{|l|}{ RHEOCRI } \\
\hline THIENEM & 71 & & & & 5 & & & 171 & & \\
\hline TVETE & 401 & 227 & 5 & 326 & 666 & & & & 27 & 177 \\
\hline METRIOC & & & & & & & & 1,029 & & \\
\hline \multicolumn{11}{|l|}{ PAROC } \\
\hline ODONTO & 39 & & 5 & & 11 & & & & & \\
\hline NIMYIA & & 10 & & 11 & 25 & & & & 1 & \\
\hline ZAVRELI & & & 10 & & & 108 & & & & \\
\hline TANYPUS & & & & & & & & & & 3 \\
\hline CULICI & & & & & & 15 & 150 & & & \\
\hline DIXID & & & & & & & 30 & & & \\
\hline \multicolumn{11}{|l|}{ DIXASP } \\
\hline \multicolumn{11}{|l|}{ MERINGO } \\
\hline \multicolumn{11}{|l|}{ PSYCHOD } \\
\hline PROSIMU & & & & & & & & & 2 & \\
\hline SIMULIU & 323 & 90 & 187 & 83 & 30 & & & & 34 & 182 \\
\hline MOLOPH & & 9 & & 5 & & & & & & \\
\hline \multicolumn{11}{|l|}{ PEDICI } \\
\hline \multicolumn{11}{|l|}{ DICRAN } \\
\hline \multicolumn{11}{|l|}{ TIPULA } \\
\hline DOLICHO & & & & & & & & & & \\
\hline
\end{tabular}


78 Mormon Cricket Control in Utah's West Desert-Evaluation of Impacts of the Pesticide Diflubenzuron

Ibapah sites-Continued.

\begin{tabular}{|c|c|c|c|c|c|c|c|c|c|c|}
\hline Code & $\begin{array}{c}\text { MCST } \\
7 / 12\end{array}$ & $\begin{array}{c}\text { SDST } \\
7 / 13\end{array}$ & $\begin{array}{c}\text { JCST } \\
7 / 13\end{array}$ & $\begin{array}{c}\text { IJCST } \\
7 / 13\end{array}$ & $\begin{array}{l}\text { ICST } \\
7 / 14\end{array}$ & $\begin{array}{c}\text { NOXSP } \\
7 / 13\end{array}$ & $\begin{array}{c}\text { SOXSP } \\
7 / 13\end{array}$ & $\begin{array}{c}\text { SKSP } \\
7 / 13\end{array}$ & $\begin{array}{c}\text { BCST } \\
7 / 13\end{array}$ & $\begin{array}{c}\text { DCST } \\
7 / 14\end{array}$ \\
\hline EMPIDI & & & 3 & & & & & & & \\
\hline CLINOCE & & & & 5 & & & & & & \\
\hline \multicolumn{11}{|l|}{ EPHYDR } \\
\hline SCIOMYZ & & & & & & & 30 & & & \\
\hline
\end{tabular}

Vernon sites

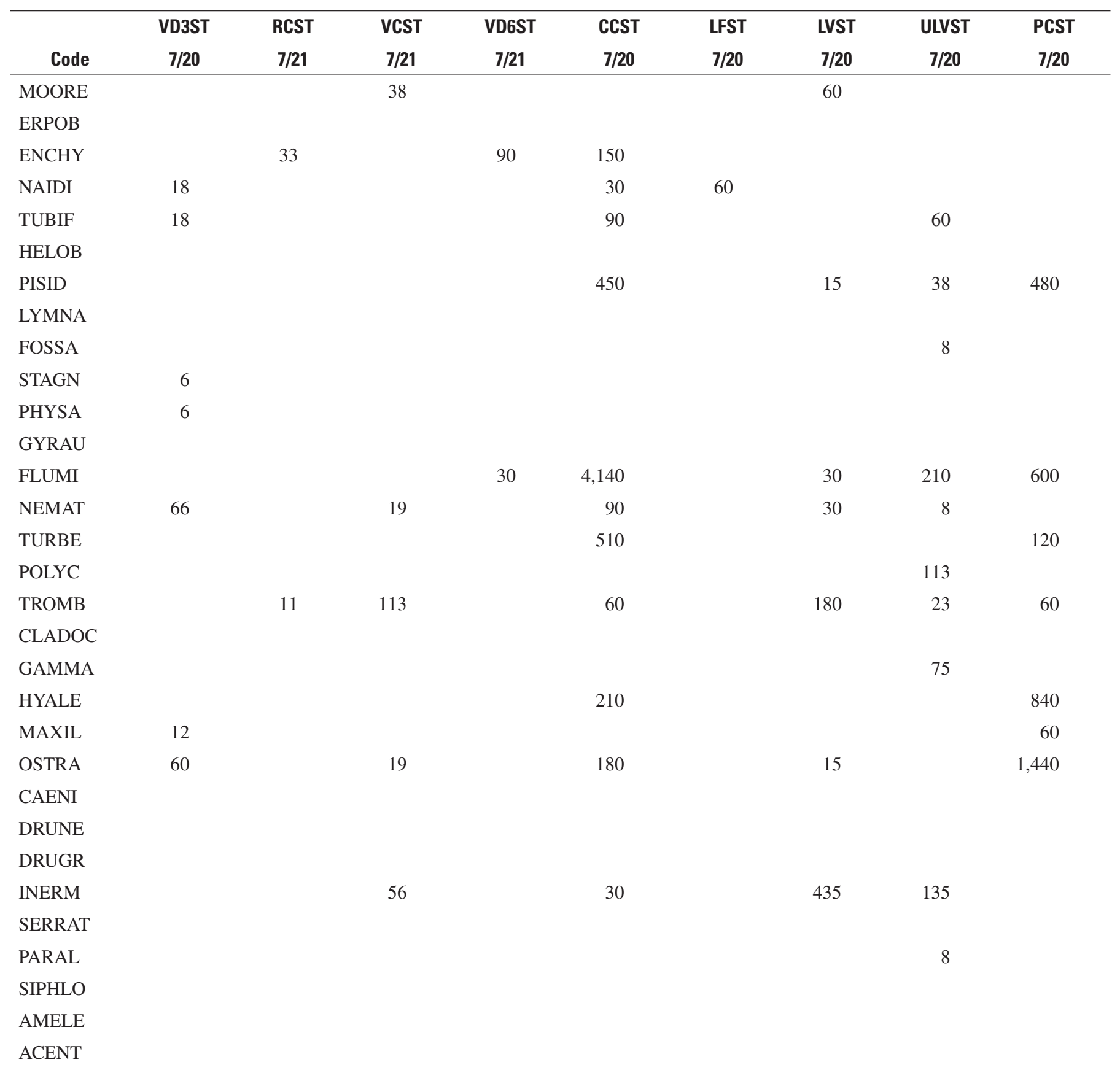


Vernon sites-Continued.

\begin{tabular}{|c|c|c|c|c|c|c|c|c|c|}
\hline Code & $\begin{array}{c}\text { VD3ST } \\
7 / 20 \\
\end{array}$ & $\begin{array}{c}\text { RCST } \\
\text { 7/21 } \\
\end{array}$ & $\begin{array}{c}\text { VCST } \\
7 / 21 \\
\end{array}$ & $\begin{array}{c}\text { VD6ST } \\
7 / 21 \\
\end{array}$ & $\begin{array}{c}\text { CCST } \\
7 / 20 \\
\end{array}$ & $\begin{array}{l}\text { LFST } \\
7 / 20 \\
\end{array}$ & $\begin{array}{c}\text { LVST } \\
\text { 7/20 }\end{array}$ & $\begin{array}{c}\text { ULVST } \\
7 / 20 \\
\end{array}$ & $\begin{array}{c}\text { PCST } \\
7 / 20 \\
\end{array}$ \\
\hline BAETI & & 2,182 & 300 & 6,480 & 960 & 1,860 & 225 & 458 & 2,040 \\
\hline \multicolumn{10}{|l|}{ CENTR } \\
\hline DIPHE & & & & & 60 & & & 23 & 120 \\
\hline \multicolumn{10}{|l|}{ EGRAND } \\
\hline \multicolumn{10}{|l|}{ EDECEPT } \\
\hline \multicolumn{10}{|l|}{ ELONGIM } \\
\hline \multicolumn{10}{|l|}{ AESHN } \\
\hline \multicolumn{10}{|l|}{ ANAXSP } \\
\hline \multicolumn{10}{|l|}{ LIBEL } \\
\hline \multicolumn{10}{|l|}{ ERYTHEM } \\
\hline \multicolumn{10}{|l|}{ LIBELSP } \\
\hline \multicolumn{10}{|l|}{ SYMPE } \\
\hline \multicolumn{10}{|l|}{ HETAER } \\
\hline \multicolumn{10}{|l|}{ COENAGR } \\
\hline \multicolumn{10}{|l|}{ AMPHIAG } \\
\hline \multicolumn{10}{|l|}{ ENALLAG } \\
\hline \multicolumn{10}{|l|}{ LESTES } \\
\hline \multicolumn{10}{|l|}{ MALENKA } \\
\hline ZAPAOR & & & & & & 60 & & & \\
\hline \multicolumn{10}{|l|}{ TAENIOP } \\
\hline \multicolumn{10}{|l|}{ CHLORO } \\
\hline ISOPER & & & 38 & & 60 & & 30 & 8 & \\
\hline PTERON & & & & & & & & 15 & \\
\hline CORIXID & 84 & & & & & & & & \\
\hline \multicolumn{10}{|l|}{ CENOCOR } \\
\hline HCORIXA & & & & & & & & & \\
\hline SIGARAS & & & & & & & & & \\
\hline NOTONE & & & & & & & & & \\
\hline HPSYCHI & & & & & & & & & \\
\hline HPSYCSP & & & 75 & & & & 75 & 38 & \\
\hline AMIOCE & & & & & & & & & \\
\hline BRACHYC & & & & & & & & & \\
\hline MICRAS & & & & & & & & & \\
\hline
\end{tabular}


80 Mormon Cricket Control in Utah's West Desert-Evaluation of Impacts of the Pesticide Diflubenzuron

Vernon sites-Continued.

\begin{tabular}{|c|c|c|c|c|c|c|c|c|c|}
\hline Code & $\begin{array}{c}\text { VD3ST } \\
\text { 7/20 }\end{array}$ & $\begin{array}{c}\text { RCST } \\
7 / 21 \\
\end{array}$ & $\begin{array}{c}\text { VCST } \\
7 / 21 \\
\end{array}$ & $\begin{array}{c}\text { VD6ST } \\
7 / 21 \\
\end{array}$ & $\begin{array}{c}\text { CCST } \\
7 / 20 \\
\end{array}$ & $\begin{array}{l}\text { LFST } \\
7 / 20 \\
\end{array}$ & $\begin{array}{c}\text { LVST } \\
7 / 20 \\
\end{array}$ & $\begin{array}{c}\text { ULVST } \\
7 / 20 \\
\end{array}$ & $\begin{array}{c}\text { PCST } \\
7 / 20 \\
\end{array}$ \\
\hline LEPIDO & & & & & & & 15 & 30 & \\
\hline \multicolumn{10}{|l|}{ LEPTO } \\
\hline \multicolumn{10}{|l|}{ YLODE } \\
\hline \multicolumn{10}{|l|}{ LIMNE } \\
\hline \multicolumn{10}{|l|}{ ECCLISO } \\
\hline PHILAR & & & & & 45 & & & & \\
\hline HESPER & & & 113 & & 135 & & 120 & 45 & 60 \\
\hline LEPHILU & & & & & & & & 45 & \\
\hline \multicolumn{10}{|l|}{ HPTILID } \\
\hline \multicolumn{10}{|l|}{ HPTILSP } \\
\hline OCHROT & & & & & & & 30 & & \\
\hline RHYACO & & & & & 30 & & & & \\
\hline DYTISCI & & 22 & & 30 & & 60 & & 15 & \\
\hline \multicolumn{10}{|l|}{ AGABU } \\
\hline \multicolumn{10}{|l|}{ COLYMB } \\
\hline \multicolumn{10}{|l|}{ RHANTU } \\
\hline \multicolumn{10}{|l|}{ LIODESS } \\
\hline \multicolumn{10}{|l|}{ HYGROTU } \\
\hline STICTOT & 6 & & & & & & & & \\
\hline \multicolumn{10}{|l|}{ LACCOPH } \\
\hline \multicolumn{10}{|l|}{ PELTODY } \\
\hline CLEPTEL & & & 19 & & & & 75 & & \\
\hline OPTIOSE & & & 75 & & 150 & & 480 & 210 & 540 \\
\hline \multicolumn{10}{|l|}{ OCHTHEB } \\
\hline \multicolumn{10}{|l|}{ HPHILID } \\
\hline \multicolumn{10}{|l|}{ HYBIUS } \\
\hline \multicolumn{10}{|l|}{ LACCOB } \\
\hline \multicolumn{10}{|l|}{ TROPIST } \\
\hline \multicolumn{10}{|l|}{ AGATH } \\
\hline CERATOP & & & & & 30 & & & 15 & \\
\hline \multicolumn{10}{|l|}{ APEDILU } \\
\hline \multicolumn{10}{|l|}{ CHIRONO } \\
\hline PARACHI & 6 & & & & & & & & \\
\hline PARACLA & & & & & & & 16 & & \\
\hline \multicolumn{10}{|l|}{ PARATEN } \\
\hline PHAENOP & 43 & & & & 62 & & 93 & & \\
\hline POLYPED & & & & & 31 & 60 & & & \\
\hline \multicolumn{10}{|l|}{ PSEUDOC } \\
\hline TARSINI & & & & & & & & & \\
\hline CLADOT & & & & & & & & & \\
\hline MICROPS & 1488 & & & & 1,246 & 11,743 & 264 & 38 & 4,689 \\
\hline
\end{tabular}


Vernon sites-Continued.

\begin{tabular}{|c|c|c|c|c|c|c|c|c|c|}
\hline Code & $\begin{array}{c}\text { VD3ST } \\
7 / 20\end{array}$ & $\begin{array}{c}\text { RCST } \\
7 / 21\end{array}$ & $\begin{array}{c}\text { VCST } \\
7 / 21\end{array}$ & $\begin{array}{c}\text { VD6ST } \\
7 / 21\end{array}$ & $\begin{array}{c}\text { CCST } \\
7 / 20\end{array}$ & $\begin{array}{l}\text { LFST } \\
7 / 20\end{array}$ & $\begin{array}{l}\text { LVST } \\
7 / 20\end{array}$ & $\begin{array}{c}\text { ULVST } \\
7 / 20\end{array}$ & $\begin{array}{c}\text { PCST } \\
7 / 20\end{array}$ \\
\hline \multicolumn{10}{|l|}{ RHEOTAN } \\
\hline \multicolumn{10}{|l|}{ STEMPEL } \\
\hline TANYTAR & & & & & & 60 & & & \\
\hline PAGAS & & & & & & 241 & & 8 & 61 \\
\hline \multicolumn{10}{|l|}{ DIAMES } \\
\hline \multicolumn{10}{|l|}{ ACRICOT } \\
\hline BRILLIA & & & & & & & & 8 & \\
\hline CHAETOC & & & & & & & 17 & & \\
\hline EUKBREH & & & 19 & & 70 & 181 & & 8 & 63 \\
\hline EUKDEVO & & & & & & & 33 & & 63 \\
\hline EUKGRAC & & & & & 35 & & 17 & & \\
\hline EUKCLAR & & & 56 & & 35 & 542 & 66 & 61 & 254 \\
\hline LIMNOP & & & & & & 60 & & & \\
\hline ORTHOC & 43 & & 38 & & & 602 & 83 & 30 & 63 \\
\hline PARAKI & 62 & & & & & & & & \\
\hline PARAME & & & & 90 & 70 & & & & 63 \\
\hline \multicolumn{10}{|l|}{ PSECTRC } \\
\hline \multicolumn{10}{|l|}{ PSEUDOS } \\
\hline METRIOC & & & & & & & & & 63 \\
\hline PAROC & & & & & & 181 & & & \\
\hline ODONTO & & & & & & & 109 & 8 & 61 \\
\hline PRODIA & & & & & & & 16 & & 61 \\
\hline \multicolumn{10}{|l|}{ TANYPOD } \\
\hline ASPECTR & & & & & & & & & 61 \\
\hline \multicolumn{10}{|l|}{ PSECTRT } \\
\hline RADOTA & & & & & & & 31 & & 61 \\
\hline \multicolumn{10}{|l|}{ PENTA } \\
\hline NIMYIA & & & & & & & & & 61 \\
\hline \multicolumn{10}{|l|}{ ZAVRELI } \\
\hline \multicolumn{10}{|l|}{ TANYPUS } \\
\hline CULICI & 6 & & & & & & & & \\
\hline \multicolumn{10}{|l|}{ DIXID } \\
\hline DIXASP & & & & & 30 & & & 45 & 120 \\
\hline
\end{tabular}


82 Mormon Cricket Control in Utah's West Desert-Evaluation of Impacts of the Pesticide Diflubenzuron

Vernon sites-Continued.

\begin{tabular}{|c|c|c|c|c|c|c|c|c|c|}
\hline Code & $\begin{array}{c}\text { VD3ST } \\
7 / 20\end{array}$ & $\begin{array}{c}\text { RCST } \\
7 / 21\end{array}$ & $\begin{array}{c}\text { VCST } \\
7 / 21\end{array}$ & $\begin{array}{c}\text { VD6ST } \\
7 / 21\end{array}$ & $\begin{array}{c}\text { CCST } \\
7 / 20\end{array}$ & $\begin{array}{l}\text { LFST } \\
7 / 20\end{array}$ & $\begin{array}{c}\text { LVST } \\
7 / 20\end{array}$ & $\begin{array}{c}\text { ULVST } \\
\text { 7/20 }\end{array}$ & $\begin{array}{c}\text { PCST } \\
7 / 20\end{array}$ \\
\hline \multicolumn{10}{|l|}{ MERINGO } \\
\hline \multicolumn{10}{|l|}{ PROSIMU } \\
\hline SIMULIU & 30 & 764 & 5,250 & 2,820 & 180 & 1,020 & 1,665 & 368 & 4,860 \\
\hline PEDICI & & & & & & & & & 60 \\
\hline DICRAN & & & & & 30 & & & & 60 \\
\hline \multicolumn{10}{|l|}{ TIPULA } \\
\hline \multicolumn{10}{|l|}{ DOLICHO } \\
\hline \multicolumn{10}{|l|}{ EPHYDR } \\
\hline MUSCIDA & & 65 & 19 & 60 & & 420 & & & 60 \\
\hline SCIOMYZ & & & & & & & & & \\
\hline
\end{tabular}


This page intentionally left blank 
